PNL-10285

UC-

2010

\title{
Estimated Recharge Rates at the Hanford Site
}

M. J. Fayer

T. B. Walters

February 1995

Prepared for

the U.S. Department of Energy

under Contract DE-AC06-76RLO 1830

Pacific Northwest Laboratory

Richland, Washington 99352

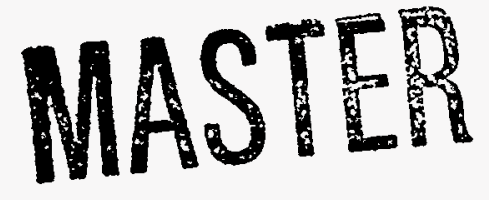





\section{DISCLAIMER}

This report was prepared as an account of work sponsored by an agency of the United States Government. Neither the United States Government nor any agency thereof, nor any of their employees, make any warranty, express or implied, or assumes any legal liability or responsibility for the accuracy, completeness, or usefulness of any information, apparatus, product, or process disclosed, or represents that its use would not infringe privately owned rights. Reference herein to any specific commercial product, process, or service by trade name, trademark, manufacturer, or otherwise does not necessarily constitute or imply its endorsement, recommendation, or favoring by the United States Government or any agency thereof. The views and opinions of authors expressed herein do not necessarily state or reflect those of the United States Government or any agency thereof. 


\section{DISCLAIMER}

Portions of this document may be illegible in electronic image products. Images are produced from the best available original document. 


\section{Summary}

The Ground-Water Surveillance Project monitors the distribution of contaminants in ground water at the Hanford Site for the U.S. Department of Energy. A subtask called "Water Budget at Hanford" was initiated in FY 1994. The objective of this subtask was to produce a defensible map of estimated recharge rates across the Hanford Site. The scope of the subtask was to estimate the recharge rates given the current surface features and using only existing data.

Recharge rates are affected by the weather and climate, soil type, vegetation, and topography. Methods that have been used to estimate recharge rates at the Hanford Site include measurements (of drainage, water contents, and tracers) and computer modeling. Estimates from these methods were assigned to specific soil-vegetation combinations and distributed across the Hanford Site using a soil map and a vegetation/land use map. The long-term average rates varied from $2.6 \mathrm{~mm} / \mathrm{yr}$ for several soil and vegetation combinations to $127.1 \mathrm{~mm} / \mathrm{yr}$ for basalt outcrop with no vegetation at the crest of Rattlesnake Mountain. For the simulations of 12 soil-vegetation combinations, the annual rates varied from $0.05 \mathrm{~mm} / \mathrm{yr}$ for the Ephrata sandy loam with bunchgrass to $85.2 \mathrm{~mm} / \mathrm{yr}$ for the same soil without vegetation. Water content data from the Grass Site in the 300 Area indicated that annual rates varied from 3.0 to $143.5 \mathrm{~mm} / \mathrm{yr}$ during an 8-year period. These variations reflect differences in soil type and vegetation as well as year-to-year weather variations.

The annual volume of estimated recharge was calculated to be $8.47 \times 10^{9} \mathrm{~L}$ for the potential future Hanford Site (i.e., the portion of the current Site bounded by Highway 240 and the Columbia River). This total volume is similar to earlier estimates of natural recharge and is 2 to 10x higher than estimates of runoff and ground-water flow from higher elevations. Relative to facility discharges in the 200 Areas in 1992, the volume of natural recharge is equivalent. Not only is the volume of natural recharge significant in comparison to other ground-water inputs, the distribution of estimated recharge is highly skewed to the disturbed sandy soils (i.e., the 200 Areas, where most contaminants originate). The lack of good estimates of the means and variances of the supporting data (i.e., the soil map, the vegetation/land use map, the model parameters) translates into large uncertainties in the recharge estimates. When combined, the significant quantity of estimated recharge, its high sensitivity to disturbance, and the unquantified uncertainty of the data and model parameters suggest that the defensibility of the recharge estimates should be improved.

Six ways to increase the defensibility of the recharge map were recommended. A new soil survey by the Soil Conservation Service would help tremendously, especially if it included collection of recharge-related information. The information from an ongoing vegetation survey that is collecting valuable data on plant communities could be incorporated into some of the simulations to improve their predictions. The Ephrata sandy loam and Burbank loamy sand, two soil types that are prevalent in the 200 Areas, are poorly characterized. They should be studied and their hydraulic properties determined in situ. The 1984 fire had a significant impact on recharge rates because it changed the species composition. Estimates of future recharge rates should consider the frequency and impact of fire. Sixty-eight percent of the recharge volume of the future Site occurred in Rupert sand, half of that under the shrub-steppe and recovering shrub-steppe covers. Field data, either using tracers or lysimeters, should be collected to support the simulation estimates for this soil.

The last recommendation is to quantify the impact of human activity on recharge rates. Disturbed areas can contribute the largest amount of site-specific recharge, as evidenced by the $86.7 \mathrm{~mm} / \mathrm{yr}$ recharge rate beneath gravel-covered lysimeters that were constructed to mimic the surface conditions at the tank farms. The highest levels of disturbance occur in and around waste 
disposal areas, so not only could ground-water flow be affected by higher recharge rates, but contaminants could be leached and reach the ground water much more quickly. Unfortunately, little is known about the impact of disturbance on recharge in many areas of the Site. The recharge contribution from roads, power lines, firebreaks, and parking lots could far exceed the total from the estimated natural rates. Some means should be found to estimate the rate and distribution of recharge in these disturbed areas and to determine its impact on ground-water flow and transport modeling.

The map that was produced for this report does not reflect historical recharge rates; rather, the map reveals the distribution of recharge that was estimated using the current climate and the 1991 vegetation/land use patterns. Exactly when these estimated rates will impact the water table depends on the travel time through the unsaturated zone, which varies in thickness across the Site. 


\section{Acknowledgments}

This report would not be possible without the efforts of the many people who collected data, provided comments, offered critiques, and generally improved the content. We want especially to thank Glendon Gee and Mark Rockhold for their open-door policy, which allowed us to bother them repeatedly with questions, and for their patient reviews of innumerable drafts. We extend appreciation to Janelle Downs, who provided both the data for Figure 2.4 and the data needed to estimate mean shrub density at the Hanford Site. We are grateful to Henry Bauer (U.S. Geological Survey, Tacoma, Washington) for providing the data files that we used to generate the recharge map in Figure 1.2. We wish to thank Phil Meyer for writing the unix script that allowed us to conveniently run multiple simulations. We thank Diana Felmy for replotting the data more than once. We acknowledge John McDonald for providing estimates of the facility discharges to ground water in the 200 Areas from 1979 to 1992 . We are grateful to Bob Bryce for providing support for limited monitoring of the Grass Site in the spring of 1993. We thank Rosalind Schrempf for her editorial support. Finally, we acknowledge Stuart Luttrell for recognizing the value of this work and supporting it. This work was supported by the U.S. Department of Energy-Richland Operations Office, under the Public Safety and Resource Protection Program. 



\section{Contents}

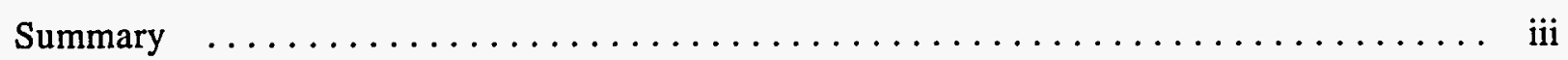

Acknowledgments $\ldots \ldots \ldots \ldots \ldots \ldots \ldots \ldots \ldots \ldots \ldots \ldots \ldots \ldots \ldots \ldots \ldots \ldots$

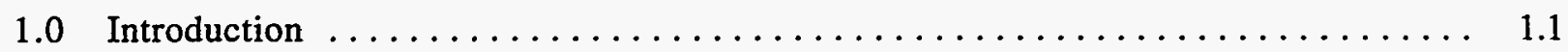

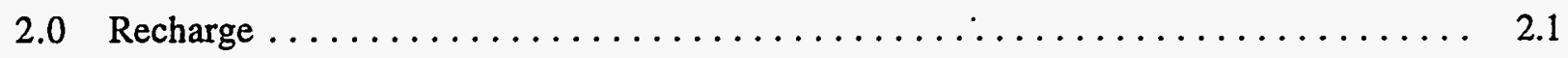

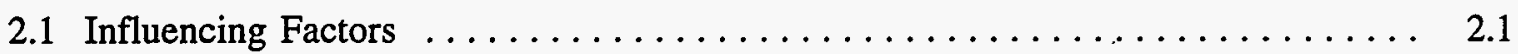

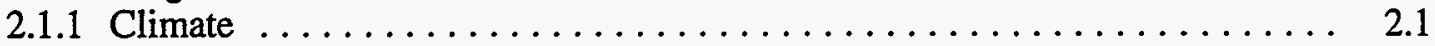

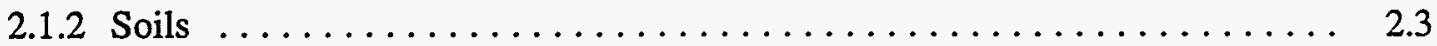

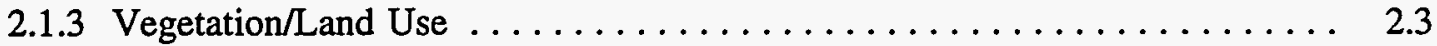

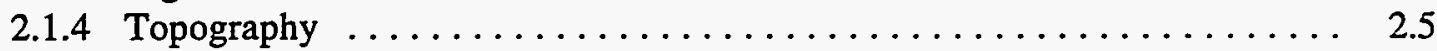

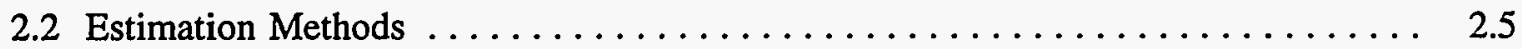

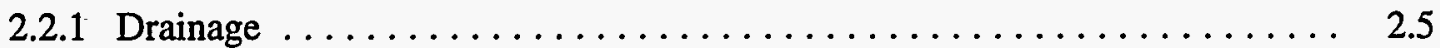

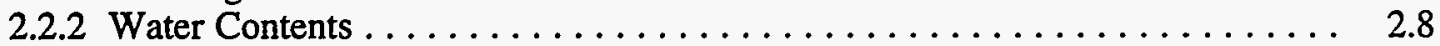

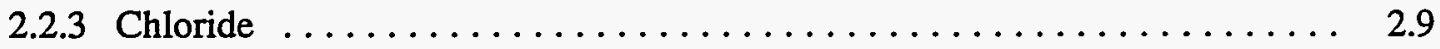

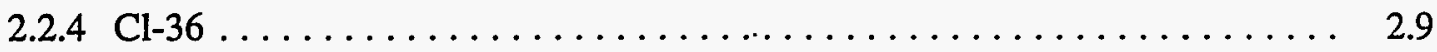

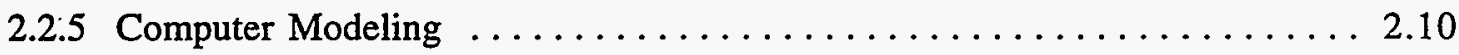

3.0 Estimated Recharge Rates $\ldots \ldots \ldots \ldots \ldots \ldots \ldots \ldots \ldots \ldots \ldots \ldots \ldots \ldots \ldots \ldots \ldots \ldots$

3.1 Assignment by Vegetation/Land Use Category $\ldots \ldots \ldots \ldots \ldots \ldots \ldots \ldots \ldots$

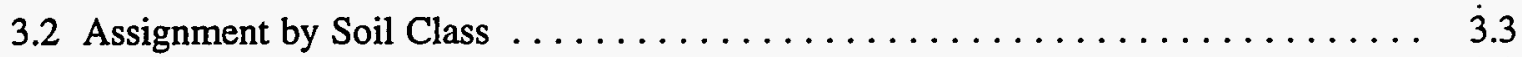

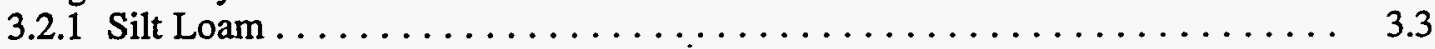

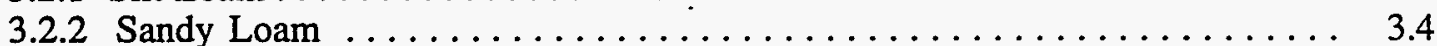

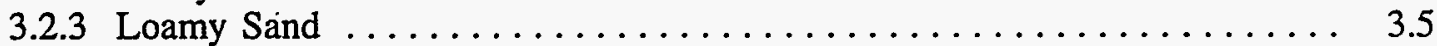

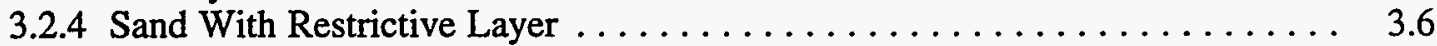

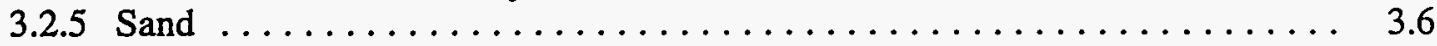

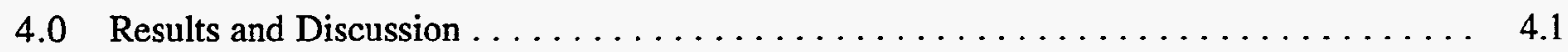

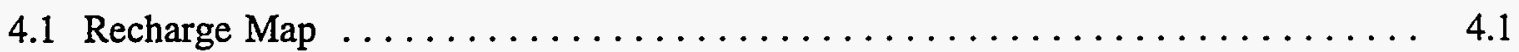

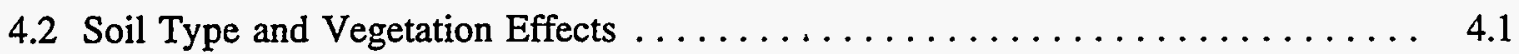

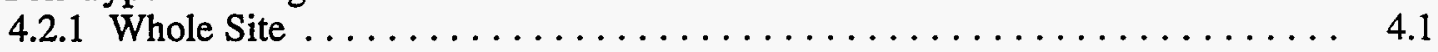

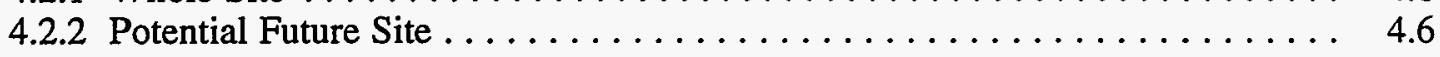

4.3 Comparison of Other Ground-Water Inputs $\ldots \ldots \ldots \ldots \ldots \ldots \ldots \ldots$

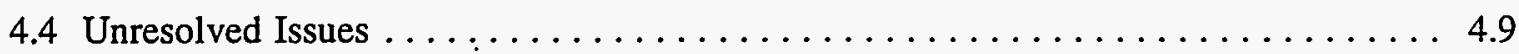

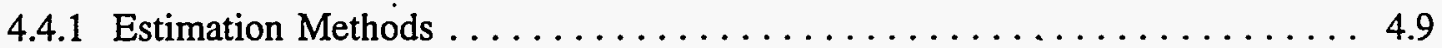

4.4.2 Appropriate Soil and Vegetation/Land Use Data . . . . . . . . . . 4.10

4.4 .3 Spatial and Temporal Averaging $\ldots \ldots \ldots \ldots \ldots \ldots \ldots \ldots \ldots \ldots \ldots \ldots \ldots \ldots \ldots \ldots \ldots .10$ 


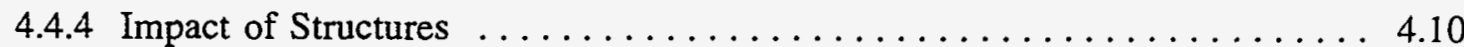

4.4.5 Basalt Outcrops and Shallow Soils ................... 4.11

5.0 Strategy for Improving the Recharge Map $\ldots \ldots \ldots \ldots \ldots \ldots \ldots \ldots \ldots \ldots \ldots \ldots$

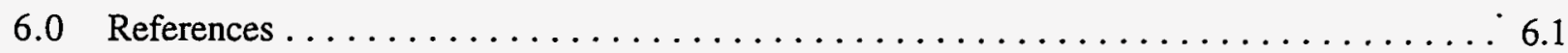

Appendix A - Estimated Recharge at the 300 Area Grass Site $\ldots \ldots \ldots \ldots \ldots \ldots$ A.1

Appendix B - Computer Simulations $\ldots \ldots \ldots \ldots \ldots \ldots \ldots \ldots \ldots \ldots \ldots \ldots \ldots \ldots \ldots \ldots$ 


\section{Figures}

1.1 Distribution of Estimated Recharge Rates at the Hanford Site (after Jacobsen

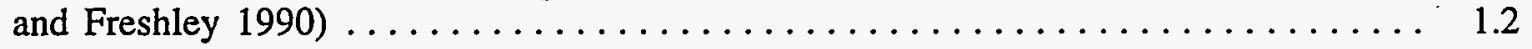

1.2 Distribution of Estimated Recharge Rates at the Hanford Site (after USGS 1990) _. . 1.3

2.1 Variation of Monthly Precipitation at the Hanford Site $\ldots \ldots \ldots \ldots \ldots \ldots \ldots .2$

2.2 Variation of Monthly Air Temperature at the Hanford Site $\ldots \ldots \ldots \ldots \ldots \ldots$

2.3 Distribution of Soils at the Hanford Site $\ldots \ldots \ldots \ldots \ldots \ldots \ldots \ldots \ldots \ldots \ldots$

2.4 Distribution of Vegetation/Land Use at the Hanford Site $\ldots \ldots \ldots \ldots \ldots$

2.5 Map of the Hanford Site Showing Locations of Measurements to Estimate

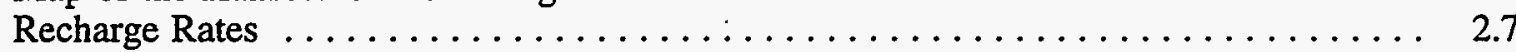

2.6 Cumulative Drainage from the South Caisson of the Buried Waste

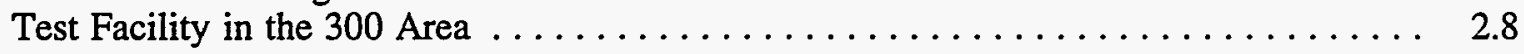

4.1 Distribution of Estimated Recharge Rates at the Hanford Site $\ldots \ldots \ldots \ldots \ldots . . \ldots$

\section{Tables}

3.1 Categories of Vegetation/Land Use at the Hanford Site and Associated Cover Types . . 3.2

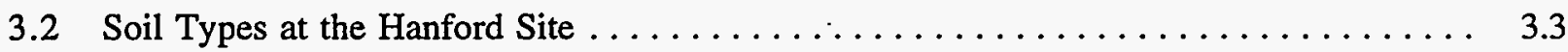

4.1 Estimated Recharge Rates at the Hanford Site for Each Combination of Soil Type and Vegetation $/$ and Use $\ldots \ldots \ldots \ldots \ldots \ldots \ldots \ldots \ldots \ldots \ldots \ldots \ldots \ldots \ldots \ldots \ldots \ldots .2$

4.2 Area of Each Combination of Soil Type and Vegetation/Land Use Within the

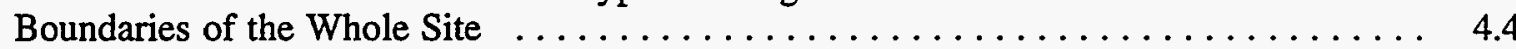

4.3 Annual Recharge Volume for Each Combination of Soil Type and Vegetation/Land Use Within the Boundaries of the Whole Site $\ldots \ldots \ldots \ldots \ldots \ldots \ldots \ldots \ldots \ldots .5$

4.4 Area of Each Combination of Soil Type and Vegetation/Land Use Within the

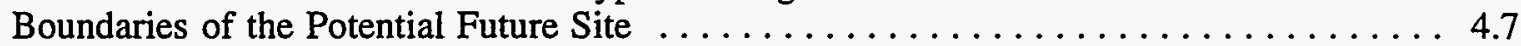

4.5 Annual Recharge Volume for Each Combination of Soil Type and Vegetation/Land Use Within the Boundaries of the Potential Future Site $\ldots \ldots \ldots \ldots \ldots \ldots \ldots . . \ldots$ 


\subsection{Introduction}

The Ground-Water Surveillance Project monitors the distribution of contaminants in ground water at the Hanford Site for the U.S. Department of Energy (DOE). The project is managed by the Pacific Northwest Laboratory (PNL) and its purpose is to assist DOE in meeting the requirements of DOE Order 5400.1 that apply to ground-water monitoring. One of the objectives of the GroundWater Surveillance Project is to assess the migration of existing ground-water contamination at the Hanford Site and the potential for the contaminants to leave the Site (Woodruff et al. 1993).

The Ground-Water Surveillance Project uses the CFEST computer code (Gupta et al. 1987) to understand the migration of contaminants in the ground water. One of the important input requirements of the CFEST code is the upper boundary condition of the modeled domain. At the Hanford Site, the upper boundary is recharge, which is the flux of water reaching the water table from the overlying unsaturated zone. Recharge comes from both natural and artificial sources. Natural recharge is the water from meteoric sources (rain and snow) that percolates below the plant root zone. Artificial recharge is the addition of water to the soil from various sources such as cribs, trenches, and ponds. Artificial recharge is well documented and is not considered further in this report.

Not many years ago, the Hanford Defense Waste Environmental Impact Statement (DOE 1987) assumed that natural recharge occurred only from rainfall and runoff from higher bordering elevations, infiltration from small ephemeral streams, and river water along influent reaches of the Columbia and Yakima rivers [an Appendix to DOE (1987) also considered recharge from irrigation of the Arid Lands Ecology Reserve]. Natural recharge across the remainder of the Site was assumed to be essentially zero. Gee et al. (1992) summarized the results of two external reviews that disputed this assumption and presented evidence from multiple experiments showing conclusively that measurable natural recharge occurs at the Hanford Site, with rates ranging from near zero to more than $100 \mathrm{~mm} / \mathrm{yr}$. The view that natural recharge is measurable and variable is now reflected in the standard National Environmental Policy Act (NEPA) documentation for the Hanford Site (Cushing 1994).

Two recent reports considered recharge across the entire Hanford Site. Jacobson and Freshley (1990) used CFEST in several applications and demonstrated how natural recharge can impact ground-water flow. Figure 1.1 shows the recharge rate distribution that they used. Jacobson and Freshley (1990) stated that their recharge distribution was based on knowledge of the soil and vegetation types on the Hanford Site, but provided no indication how the recharge rates were actually determined.

Bauer and Vaccaro (1990) simulated recharge at the Hanford Site using estimates of soil type and land use and a water balance model, which they called the Deep Percolation Model. The area of each of their simulation cells was roughly $1 \mathrm{~km}^{2}$. Figure 1.2 shows that their estimated rates for most of the Site ranged from 0 to $13 \mathrm{~mm} / \mathrm{yr}$. In the vicinity of the sand dunes in the middle of the Site, they estimated rates as high as $51 \mathrm{~mm} / \mathrm{yr}$.

Other reports ignore the impact of recharge because of the lack of good estimates of areal recharge rates. For example, Wurstner and Devary (1993) used CFEST to evaluate the potential for the tritium plume at the Hanford Site to migrate to the immediate vicinity of the City of Richland well field. They chose to specify zero natural recharge because of uncertainty in the availability of good areal recharge data for transient simulations. 


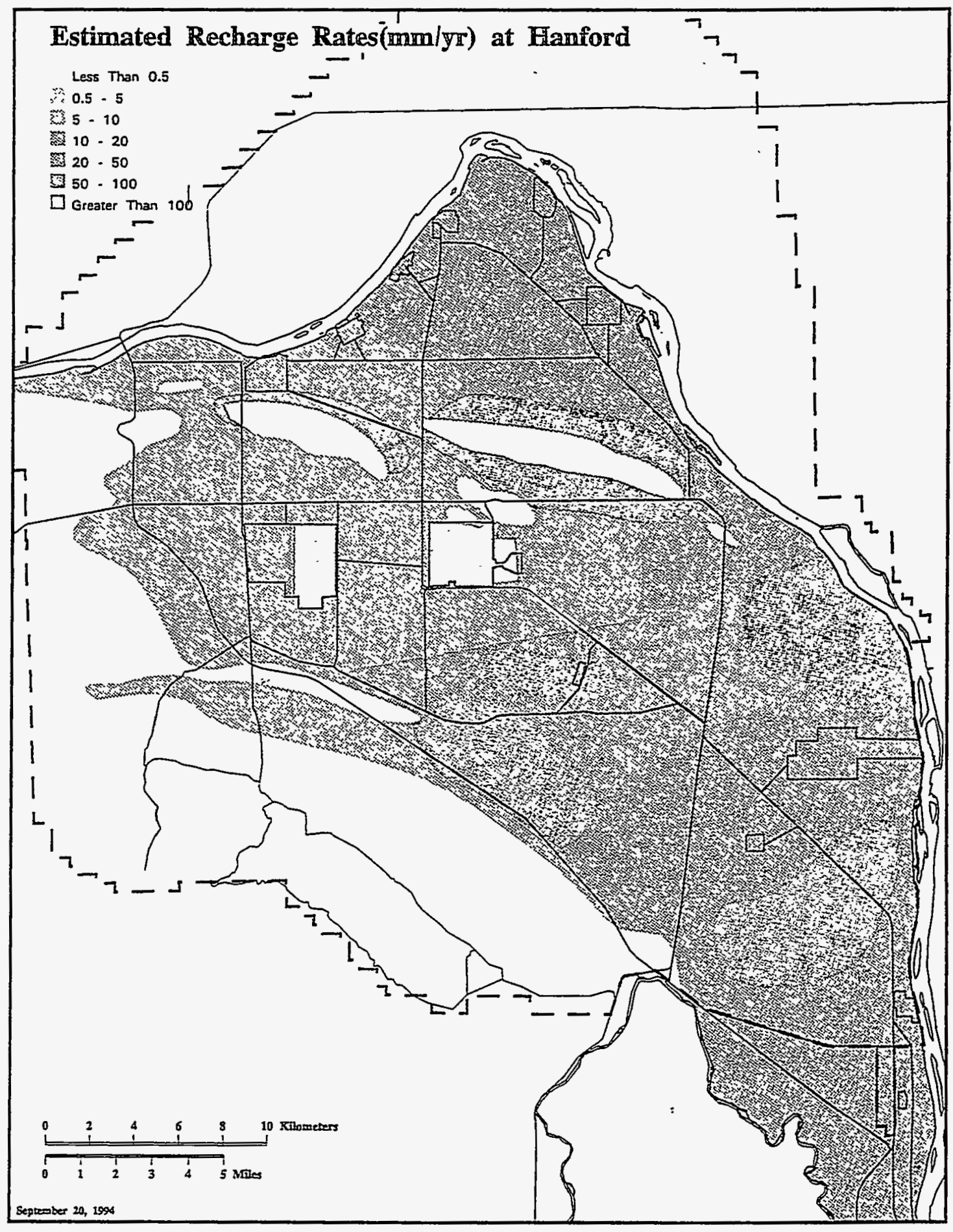

Figure 1.1. Distribution of Estimated Recharge Rates at the Hanford Site (after Jacobsen and Freshley 1990) 


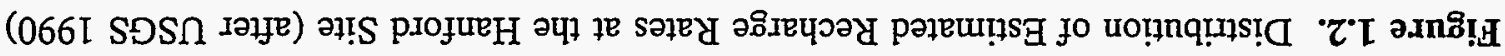

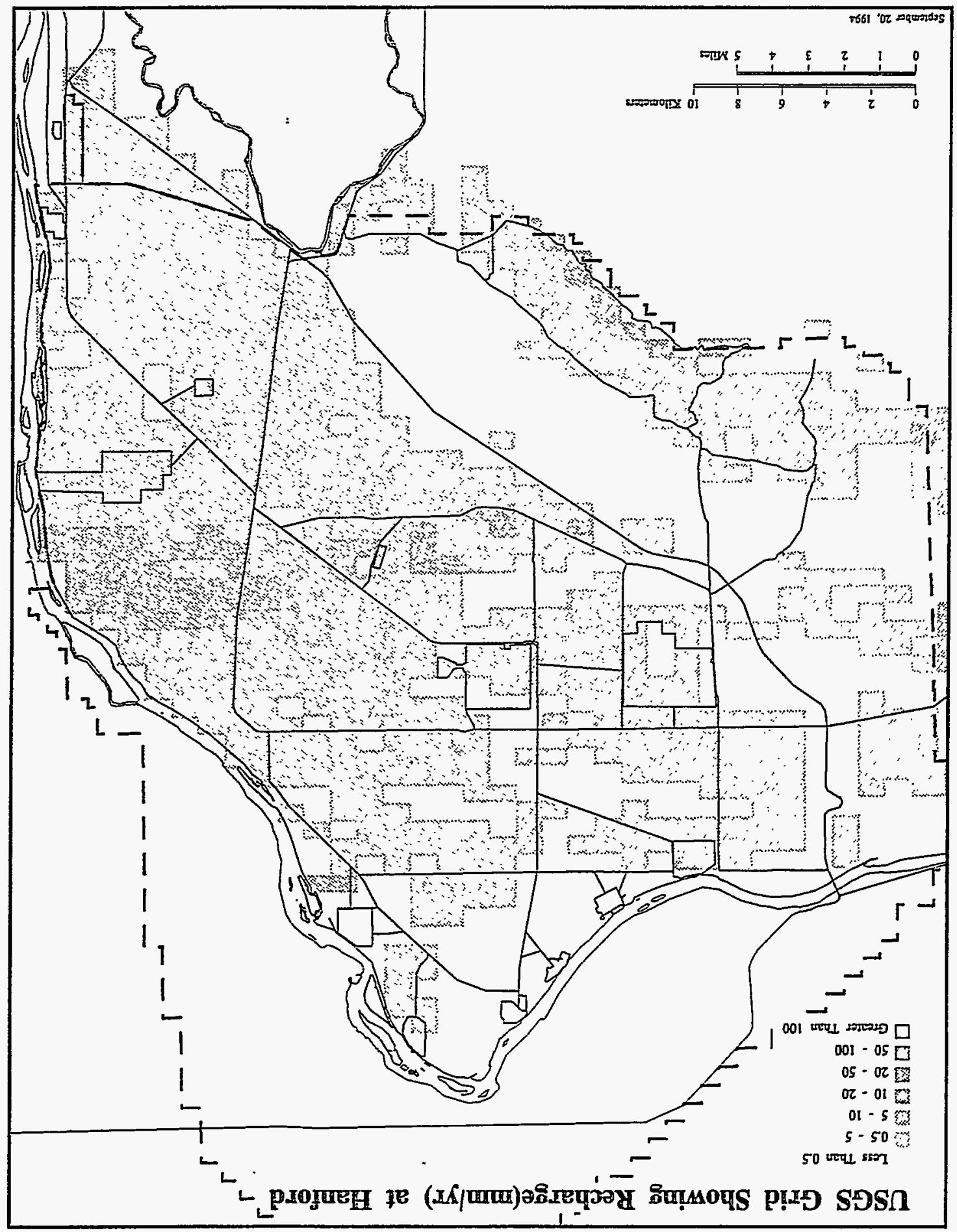


The Ground-Water Surveillance Project initiated a subtask in FY 1994 called "Water Budget at Hanford." The objective of this subtask was to produce a defensible map of estimated recharge rates across the Hanford Site. The scope of this subtask was to estimate recharge rates given the current surface features and to use only existing data. The objectives of this report are to estimate recharge rates at the Hanford Site, document the methods used to determine the estimates, produce an electronic map of the recharge rates for use in ground-water modeling, and recommend areas where recharge estimates can be improved. 


\subsection{Recharge}

Gee and Hillel (1988) observed that arid-site recharge can be generally low yet highly variable. The number of recharge measurements is usually limited, and the sampling schemes are generally random. The results from these limited and random measurements yield an average recharge rate that might be practically negligible while most of the recharge is episodic and may be confined to small areas. Gee and Hillel referred to this result as the "fallacy of averaging" in arid regions. To minimize (but unfortunately not eliminate) the impact of averaging on the recharge map, as much existing data as possible were used in the analyses. The factors that influence recharge at the Hanford Site are described below, followed by a description of estimation methods and the results from Hanford studies.

\subsection{Influencing Factors}

The magnitude of recharge at a particular location is influenced by four main factors: climate, soils, vegetation/land use, and topography. Other factors can significantly impact recharge by affecting one or more of the main factors. These other factors include soil development, animal activity, fire, disturbance, and water and wind erosion and deposition. The four main factors are described below as they relate to recharge at the Hanford Site.

\subsubsection{Climate}

Climate is the long-term average of weather variables that include precipitation, air temperature, humidity, wind speed, and solar radiation. Hoitink and Burk (1994) summarized the available weather data and associated variability at the Hanford Site for the period from 1945 to 1993.

Precipitation is a prerequisite for natural recharge to occur. Precipitation that infiltrates the soil can return to the atmosphere via evaporation, a process that depends principally on the remaining variables. Annual amounts of precipitation range from 76 to $291 \mathrm{~mm}$ (Hoitink and Burk 1994). Figure 2.1. shows that the seasonal variation of precipitation is pronounced. Precipitation in the form of snow has an even more pronounced variation; annual amounts vary from 8 to $1425 \mathrm{~mm}$. A snow cover can have a significant impact on recharge by altering the receipt of solar radiation at the ground surface and by accumulating over many days and weeks and then melting rapidly within a day or two.

Air temperature plays a significant role in evapotranspiraiton, snowfall and meit, and the phenology and growth of vegetation, all of which impact recharge. Figure 2.2 shows the variation of average monthly air temperature. Notice that the mean monthly temperature can be well below freezing for several winter months. The variation in average daily air temperatures is even greater.

Althought not plotted for this report, the seasonal variation of the remaining variables is significant. Average monthly humidities range from 66 to $145 \%$ of the mean monthly value. Average monthly wind speeds at the $15.2-\mathrm{m}$ height range from 46 to $163 \%$.of the mean monthly value. Peak wind gusts have reached $35 \mathrm{~m} / \mathrm{s}$. Solar radiation changes in a fairly predictable way throughout the year yet still has daily variability. The record shows that daily values can range from 10 to $250 \%$ of the monthly mean value, with the greatest difference occurring in the winter months when the potential for recharge is highest. 


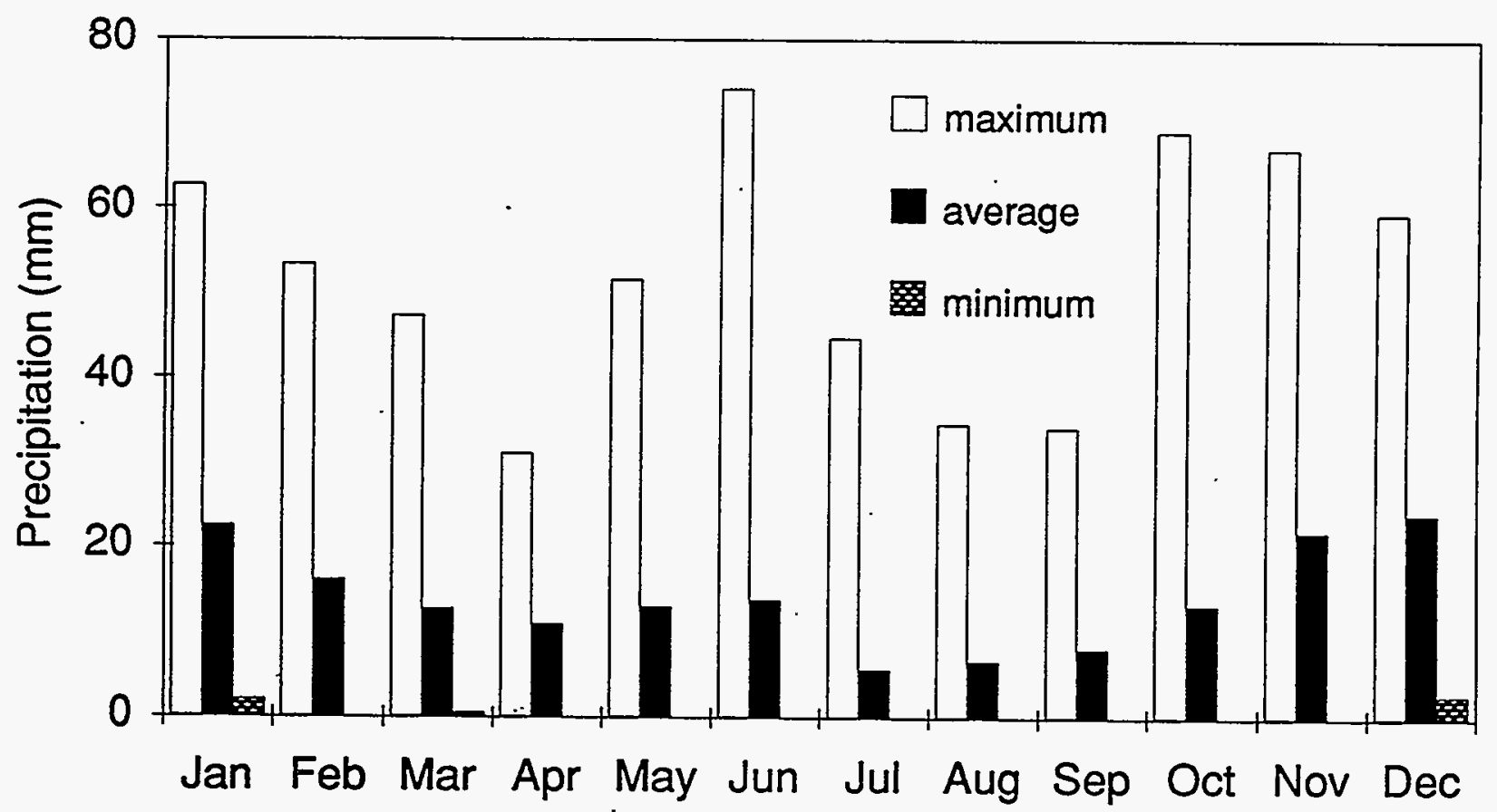

Figure 2.1. Variation of Monthly Precipitation at the Hanford Site

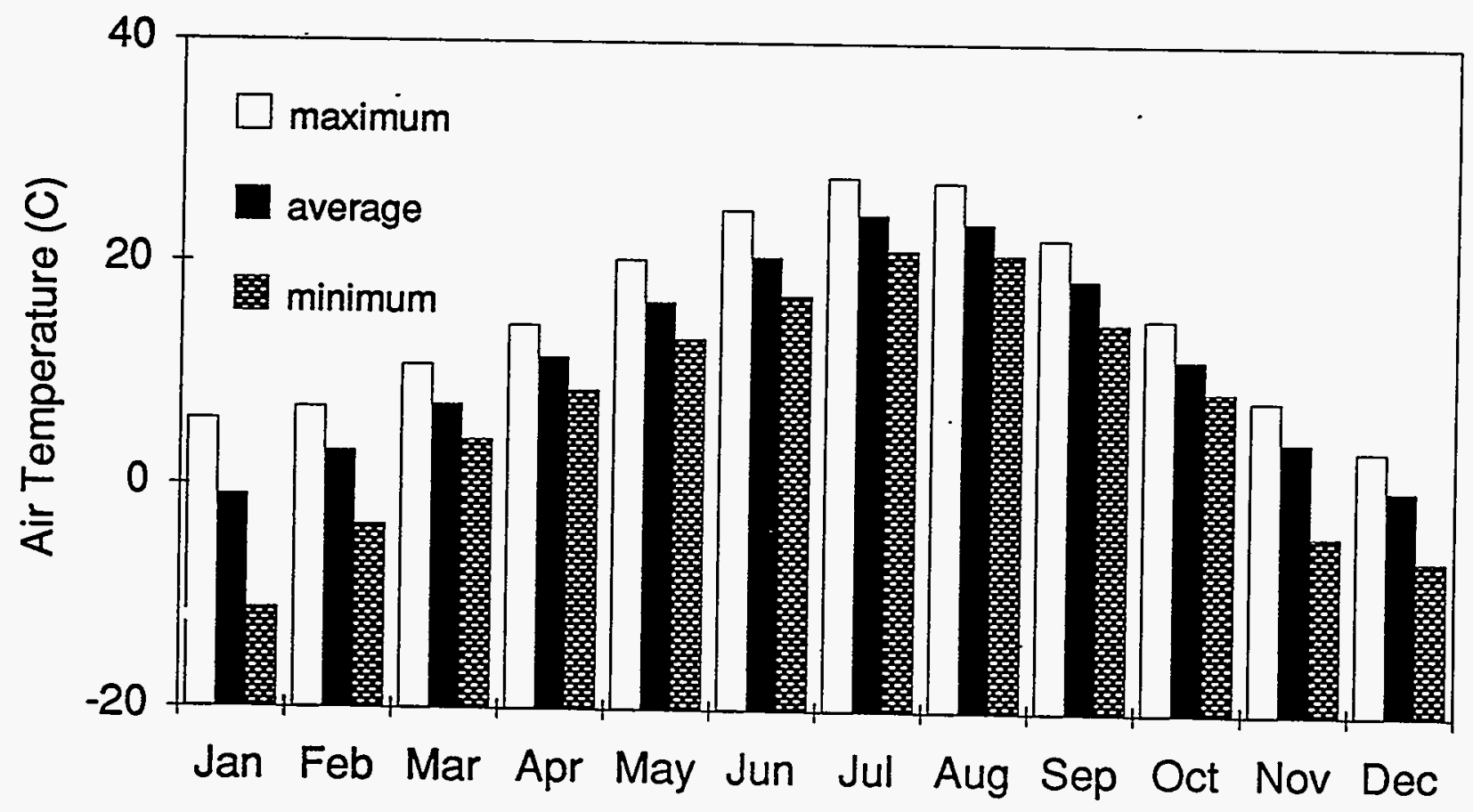

Figure 2.2. Variation of Monthly Air Temperature at the Hanford Site 
The weather variations of a given climate are sufficient to influence recharge. When the time frame of interest is greater than decades, changes in weather statistics, known as a "change in climate", can also impact recharge. Thus, predictions of climate change are important to forecasts of recharge rates.

\subsubsection{Soils}

Soil type affects recharge by controlling the partitioning of precipitation into runoff and infiltration, the storage of water, the redistribution of water within the soil, evaporation, percolation below the root zone (i.e., recharge), nutrient availability as it affects the status of vegetation, and layering.

Figure 2.3 shows the distribution of soils at the Hanford Site (Hajek 1966). Hajek (1966) reported that the information in Figure 2.3 was based on an earlier soil survey of Benton County by Kocher and Strahorn (1919). Hajek correlated the soil mapping units to the mapping units used in the 1960 s by the Soil Conservation Service, and the accuracy of the soil boundaries was spotchecked. The latest soil survey for Benton County (Rasmussen 1971) was derived from work conducted in the 1960s. It does not include the Hanford Site or the City of Richland.

\subsubsection{Vegetation/Land Use}

Vegetation plays a number of roles in the water budget of arid sites. Plants protect the soil from wind and water erosion, they are an integral part of the food chain, and they alter microclimates. Most important of all, plants remove water from the soil by the process of transpiration.

The vegetation at the Hanford Site is diverse; 590 species have been identified (Sackschewsky et al. 1992). This variety of vegetation species, each with different characteristics, is the reason that all plants do not affect the water budget in the same manner. Phenology, rooting depth, and fire resistance are some of the vegetation traits that impact the water budget.

The phenology of a plant refers to the time of year that it is active, i.e., the vegetation is growing and transpiring. Many annuals are predominantly active for a short period in spring while water is available. However, some, such as tumbleweed, are more active in summer. Perennials such as bunchgrass and sagebrush are active for longer periods during the year, partly because of their established root systems. If conditions are right, sagebrush can remove water all year long. Rickard and Vaughan (1988) compared the phenology of 12 plant taxa in both a dry year and a wet year at the Hanford Site. The length of activity varied from 2 to 10 months, depending on the species.

The root depth of vegetation determines how much soil water can be accessed by the plant. The potential for recharge is reduced as more soil water becomes accessible to the plant. Perennials such as sagebrush and bunchgrass tend to have deep root systems, sometimes as deep as $3 \mathrm{~m}$, whereas annuals such as cheatgrass tend to have shallow root systems of less than $1 \mathrm{~m}$.

Fire is part of the natural cycle at the Hanford Site. After a fire, new annual plants appear the following year from seeds that survived the fire. The speed of propagation can influence the species composition of an area. Annuals tend to grow more quickly than perennials, but only if conditions are right. Some perennials, such as bunchgrass and rabbitbrush, can regrow from their root system; 


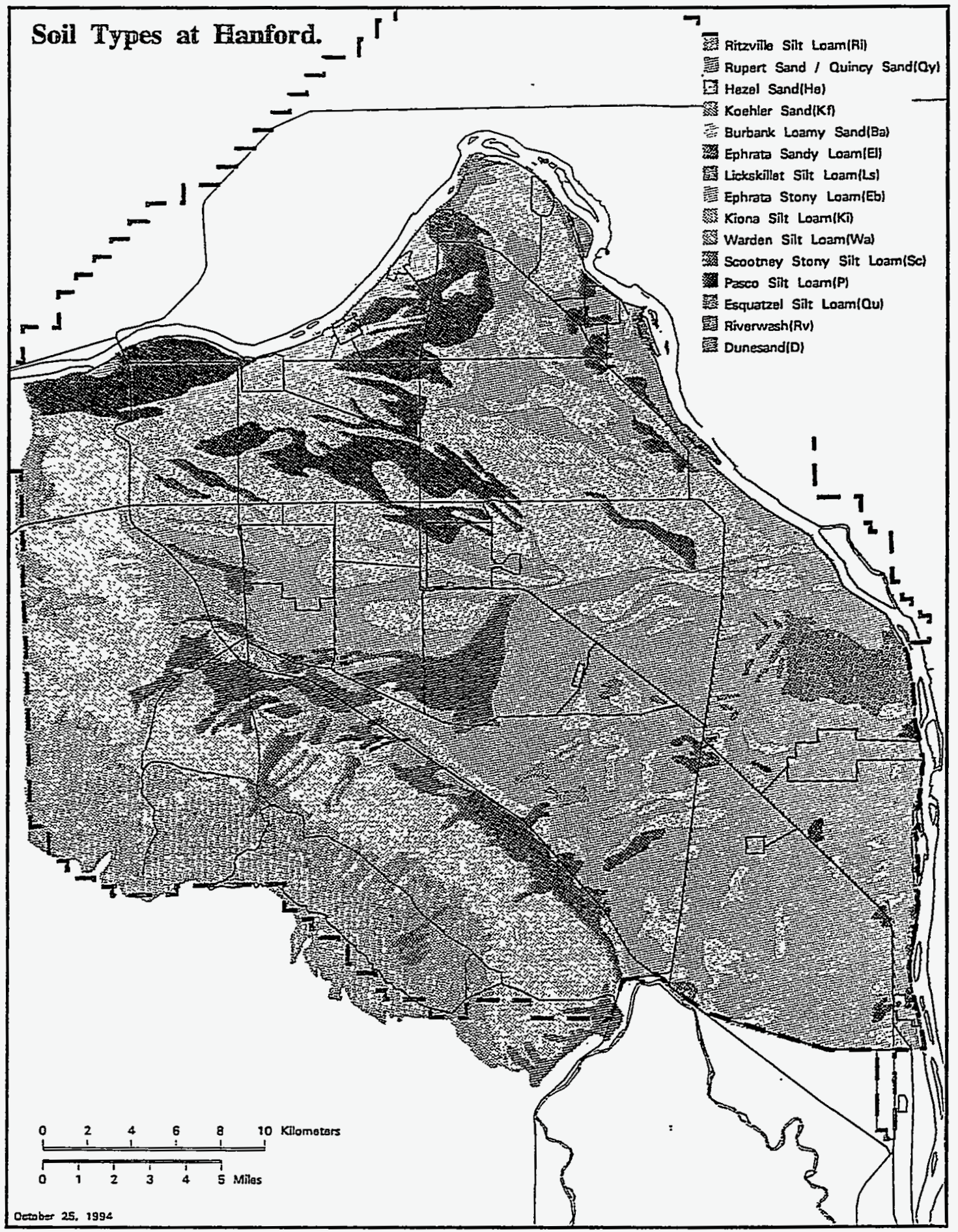

Figure 2.3. Distribution of Soils at the Hanford Site (after Hajek 1966). The area represented by each image cell is $900 \mathrm{~m}^{2}$. 
some, such as sagebrush, cannot. Thus, fire can change a plant community composition quickly, and the effects can last for years (Rickard and Vaughan 1988; Link et al. 1990).

Figure 2.4 shows the distribution of major vegetation/land use categories at the Hanford Site (Downs et al. 1993). The map was developed from aerial photos taken in 1987 and 1991; some ground surveys were used to refine the map. Downs et al. (1993) suggested that map users exercise caution when using the map without ground surveys of the area of interest. [Although not stated by Hajek (1966), the same caution should be applied to the soil map in Figure 2.3].

\subsubsection{Topography}

Variations in topography affect recharge in several ways. Large variations such as Rattlesnake Mountain alter weather by increasing precipitation and decreasing air temperatures (Thorp and Hinds 1977). Small variations, while not influencing weather, can alter microclimates (e.g., causing drifting snow to accumulate).

The aspect of the soil surface affects the receipt of solar radiation. Hinds (1975) showed significant differences in water and plant behavior between north and south facing slopes. The degree of slope affects both the receipt of solar radiation and the runoff of surface water. Local scale variations of topography can focus surface runoff in such a way that infiltration is greater and occurs in a shorter time. Water runoff does not appear prevalent at the Hanford Site because of the absence of geomorphic features such as erosion rills and gullies. However, observations have revealed that runoff does occur when there is a heavy rain or quick snowmelt and the ground is frozen (Pearce et al. 1969; Gee et al. 1988; Jones 1989).

\subsection{Estimation Methods}

The available information on recharge rates at the Hanford Site consists of measurements of water contents and drainage, tracer studies, and computer modeling. These methods were discussed in a series of papers in the January-February 1994 issue of the Soil Science Society of America Journal devoted exclusively to recharge in arid and semiarid regions. Almost all of the methods (certainly all of the methods used at the Hanford Site) estimate recharge using near-surface measurements rather than measurements at the water table. The methods that have been used at the Hanford Site are briefly described below with the data that were generated pertinent to recharge. Figure 2.5 shows the locations of measurements at the Hanford Site.

\subsubsection{Drainage}

The best method to measure recharge is to collect the water as it drains, for which lysimeters are ideally suited. Lysimeters are containers filled with sediments that are set flush with the ground surface and monitored. Some lysimeters are sealed to isolate the sediment from the lysimeter surroundings and collect water that drains to the bottom. If such lysimeters are deep enough (well below the root zone or the evaporative zone), then the drainage collected represents recharge.

Five lysimeters at the Hanford Site are configured to provide data relevant to specific combinations of soil and vegetation. The South Caisson at the Buried Waste Test Facility was filled with a medium to coarse sand $7.8 \mathrm{~m}$ deep and had no vegetation on the surface. Figure 2.6 shows cumulative drainage from July 1985 to June 1993 . For this 8-year period, the average drainage from this 


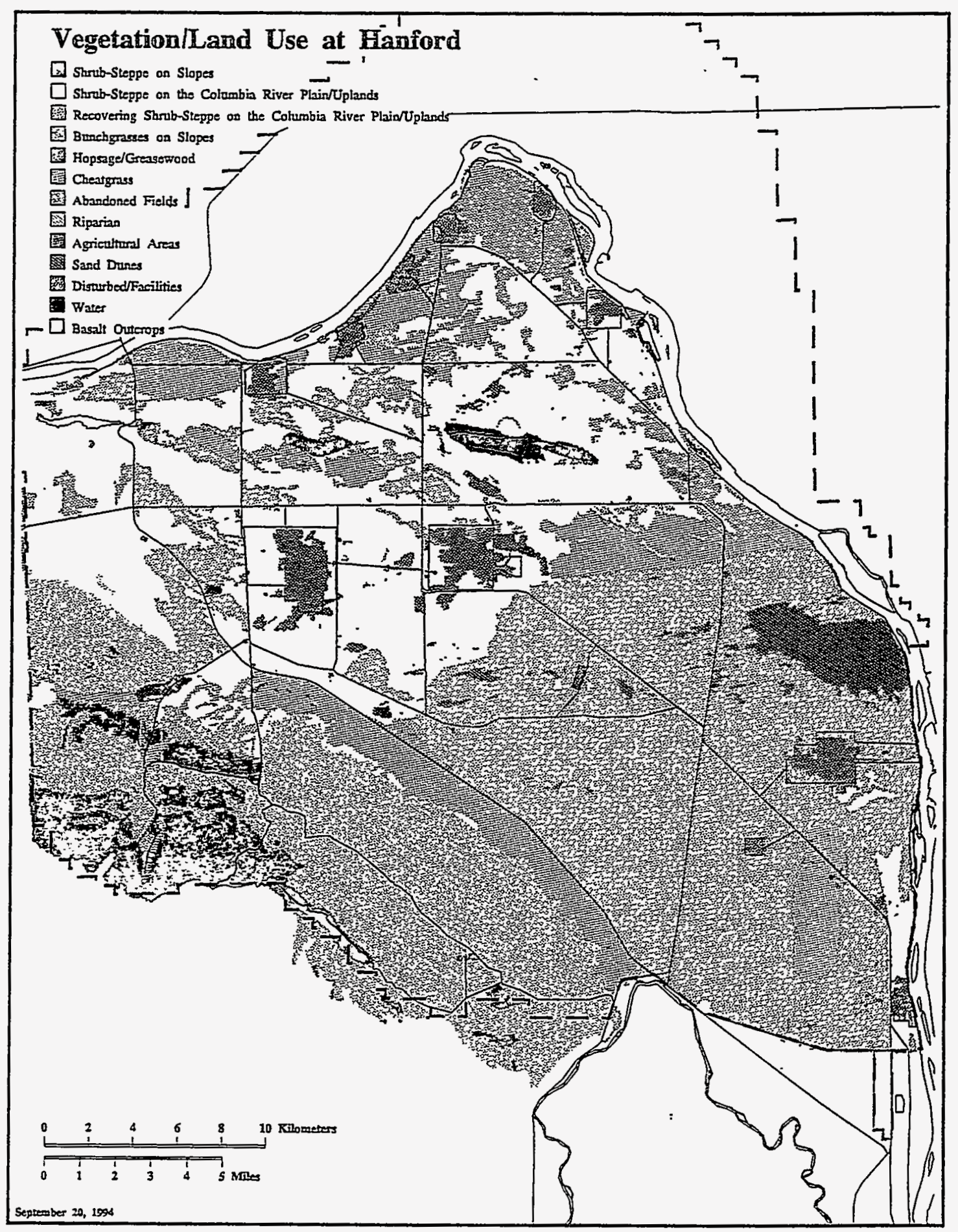

Figure 2.4. Distribution of Vegetation/Land Use at the Hanford Site (after Downs et al. 1993). The area represented by each image cell is $2500 \mathrm{~m}^{2}$. 


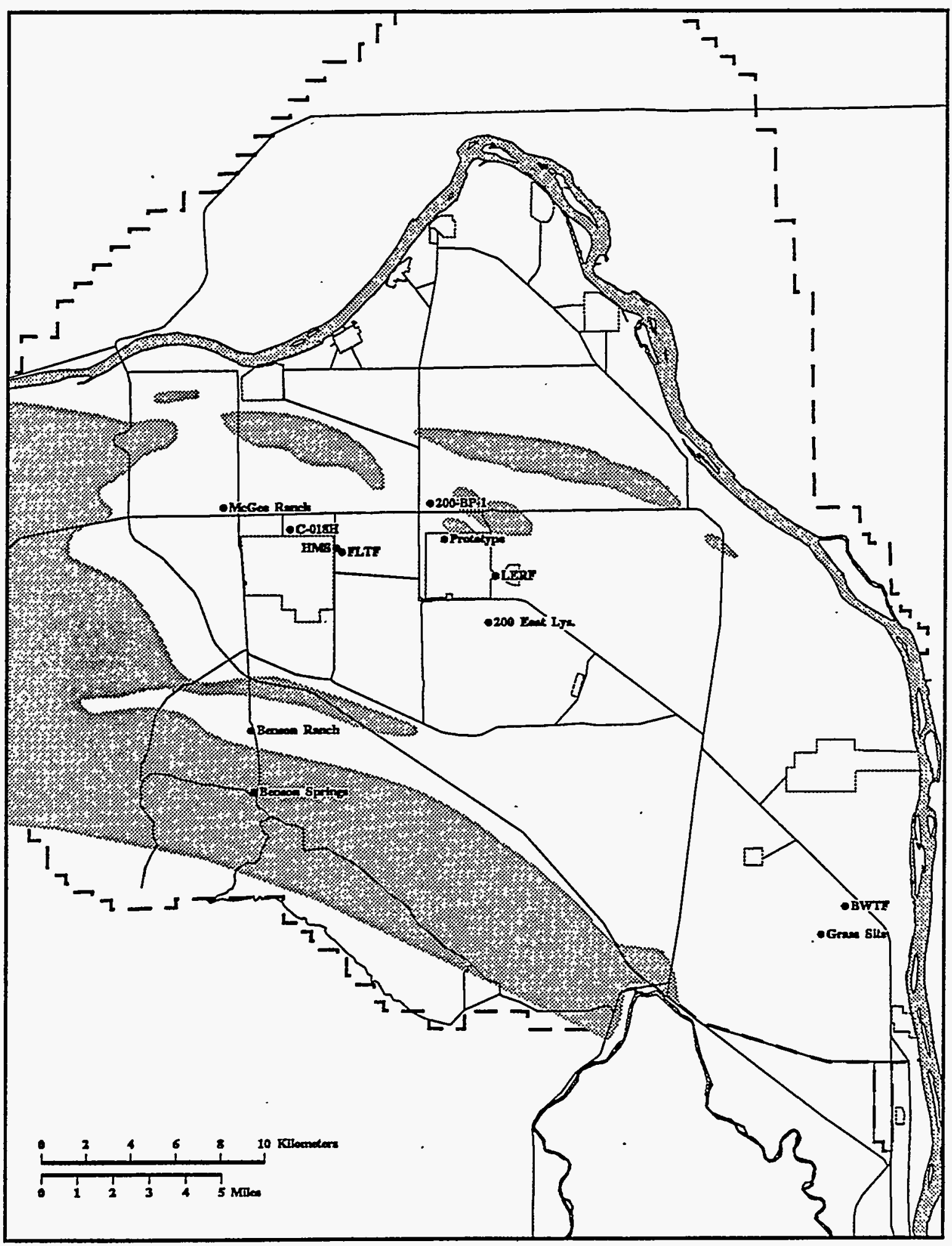

Figure 2.5. Map of the Hanford Site Showing Locations of Measurements to Estimate Recharge Rates 


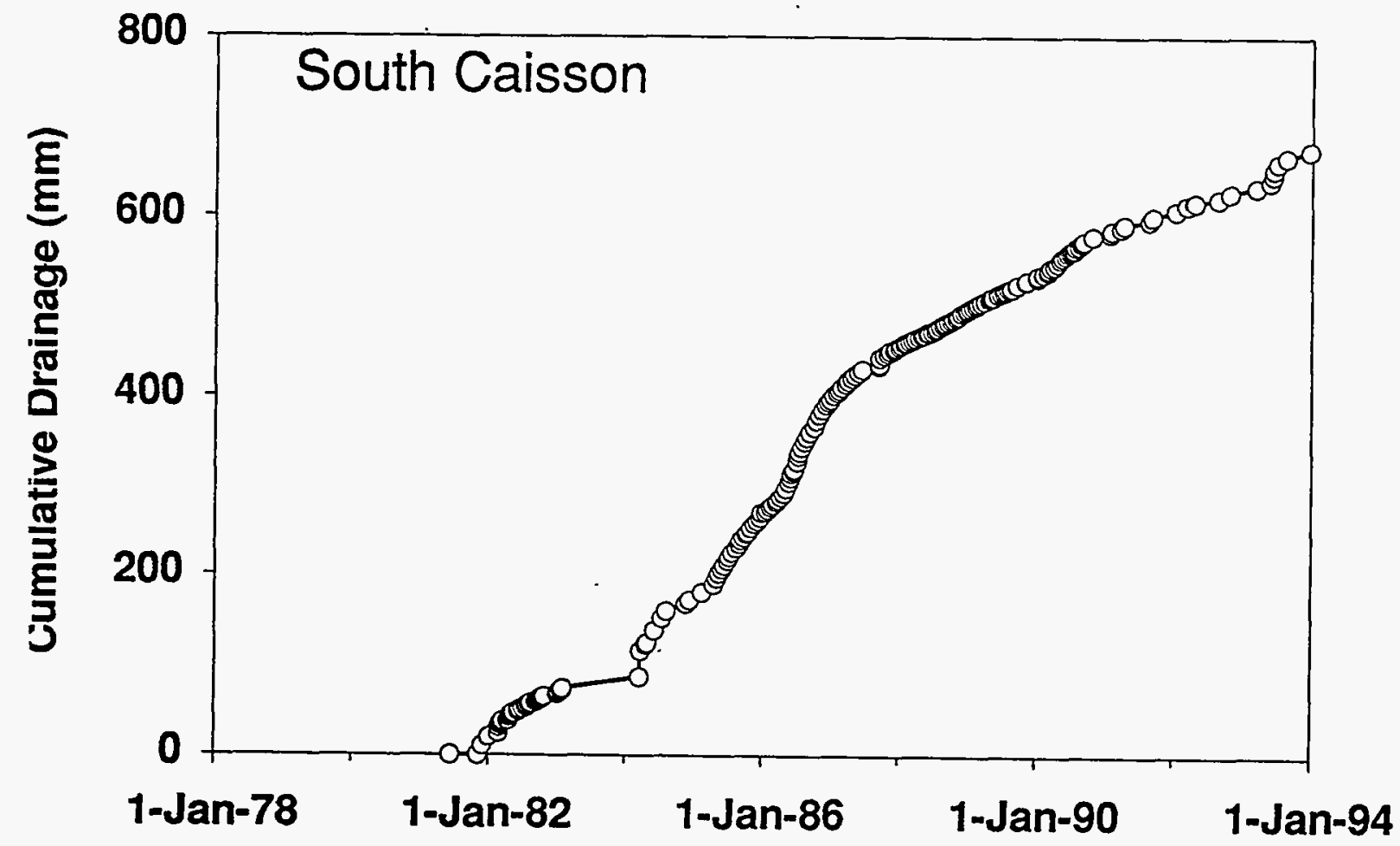

Figure 2.6. Cumulative Drainage from the South Caisson of the Buried Waste Test Facility in the 300 Area

lysimeter was $55.4 \mathrm{~mm} / \mathrm{yr}$. This rate is probably similar to the recharge rate beneath sand dunes and other disturbed sandy areas.

The clear-tube lysimeters, C01-8 and C04-10, at.the Field Lysimeter Test Facility (FLTF) are not vegetated and have a 15-cm-thick gravel layer above $135 \mathrm{~cm}$ of sand, which is above $150 \mathrm{~cm}$ of gravelly sand. Lysimeter C01-8 received ambient precipitation (184 mm/yr) and C04-10 received $3 x$ average annual precipitation $(480 \mathrm{~mm} / \mathrm{yr}$ ). From July 1990 to June 1993, the average drainage from these lysimeters was 86.7 and $300 \mathrm{~mm} / \mathrm{yr}$, respectively (Gee et al. 1993).

The clear-tube lysimeters, C02-9 and C05-11, at the FLTF are vegetated and have $150 \mathrm{~cm}$ of screened sand above $150 \mathrm{~cm}$ of gravelly sand. Lysimeter $\mathrm{C} 02-9$ received ambient precipitation $(184 \mathrm{~mm} / \mathrm{yr})$ and C05-11 received $3 \mathrm{x}$ average annual precipitation $(480 \mathrm{~mm} / \mathrm{yr})$. From July 1990 to June 1993, the average drainage from these lysimeters was 0.0 and $33.3 \mathrm{~mm} / \mathrm{yr}$, respectively (Gee et al. 1993). The reduced drainage in these lysimeters is attributed to vegetation.

\subsubsection{Water Contents}

Isolating an area with a lysimeter may be too disruptive or costly. An alternative is to measure water contents in the sediments and infer recharge rates.

The 200 East Lysimeter contains $18 \mathrm{~m}$ of sand. From 1988 to 1991, vegetation was prevented from growing and water contents were measured at various depths. During that 3-yr period, water storage increased $132 \mathrm{~mm}$ (Gee et al. 1994), and the inferred recharge rate is $44 \mathrm{~mm} / \mathrm{yr}$. This rate would be indicative of a fine sand without vegetation. 
At the Benson Springs site, Link et al. (1990) studied the water storage patterns beneath an unburned shrub-steppe community and a nearby site that burned in August 1984. At the burned site, . the bunchgrass grew back after the fire but the shrubs did not. From November 1984 to February 1989, Link et al. (1990) monitored water contents as deep as $2.75 \mathrm{~m}$. Their results showed that under the burned community, which consisted of only bunchgrass, water storage below $125 \mathrm{~cm}$ increased at the rate of $0.00843 \mathrm{~mm} / \mathrm{d}$, or roughly $3.1 \mathrm{~mm} / \mathrm{yr}$, relative to water storage in the same zone beneath the shrub-steppe community.

The Grass Site in the 300 Area is a Rupert sand with a cheatgrass-Sandberg's bluegrass cover. The surface $15 \mathrm{~cm}$ is sandy loam, underlain by $30 \mathrm{~cm}$ of loamy sand, which overlies medium to coarse sand. Water contents were monitored at this site from 1982 to 1990 to a depth of $3.5 \mathrm{~m}$. Based on annual changes in water stored below the root zone, an annual average recharge rate of $25.4 \mathrm{~mm} / \mathrm{yr}$ was inferred. Appendix A describes the calculations and shows that rates across a uniform field were variable at a 6-m spacing.

\subsubsection{Chloride}

Chloride is naturally deposited on the soil surface by precipitation and dry fallout. Because most water in the soil profile is lost to evapotranspiration, chloride tends to accumulate in and near the plant root zone. In areas where erosion is negligible, recharge is the main mechanism for removing chloride from the soil. Therefore, the distribution of excess chloride in the soil profile can be used to infer recharge rates; the major assumptions are constant chloride input and piston flow. The chloride method provides average recharge estimates for periods of 1000 s of years or longer. Recharge rates during the last 40 years cannot be calculated with this method unless the rates are high enough to move chloride below the root zone.

Murphy et al. (1991) measured chloride concentration profiles at the McGee Ranch. Based on the chloride profiles, they estimated recharge rates ranging from $<0.01$ to $2 \mathrm{~mm} / \mathrm{yr}$ over the last 10,000 years. The soil is Warden silt loam and the vegetation cover was shrub-steppe. Prych (1994 in press) measured chloride concentrations at six locations, two in silt loam soils and four in Hanford sands. At McGee Ranch and Benson Springs, Prych estimated rates that ranged from $<0.01$ to $0.44 \mathrm{~mm} / \mathrm{yr}$, depending on the calculation method. Prych reported that the soil at Benson Springs is either a Ritzville or Warden silt loam. The vegetation is shrub-steppe at both sites. At three sites in the 200 Areas, Prych reported values ranging from 0.01 to $5.5 \mathrm{~mm} / \mathrm{yr}$. The vegetation was shrubsteppe; Prych reported that the soil is either Burbank loamy sand or Ephrata sandy loam. At the Grass Site in the 300 Area, Prych reported values ranging from 0.39 to $2.0 \mathrm{~mm} / \mathrm{yr}$. The vegetation was cheatgrass and Sandberg's bluegrass; the soil is probably a Rupert sand with some fine-grained eolian material that gives the surface $15 \mathrm{~cm}$ a sandy loam texture. This estimate for the Grass Site is much lower than reported in Appendix A. The most likely reason is that the measurement periods (1000s of years for chloride; 8 years for water contents) were significantly different (e.g., different climate; different vegetation).

\subsubsection{Cl-36}

This method relies on the deposition of the $\mathrm{Cl}-36$ radionuclide that was produced during nuclear testing in the 1950s and 1960s. The amounts of this anthropogenic Cl-36 far exceeded the amounts from natural sources, thus allowing it to act as a tracer. Because the peak production occurred in approximately 1957, the $\mathrm{Cl}-36$ method yields a recharge estimate that is an average of the rate from 1957 to the respective drilling date. 
Prych (1994 in press) measured Cl-36 at four locations between 1990 and 1992. At the McGee Ranch and Benson Ranch, Prych estimated that recharge rates were $<2.1$ and $<3.4 \mathrm{~mm} / \mathrm{yr}$, respectively. Just north of the 200 West Area, Prych estimated a rate of $2.6 \mathrm{~mm} / \mathrm{yr}$. At the Grass Site in the 300 Area, Prych estimated a rate of $5.1 \mathrm{~mm} / \mathrm{yr}$, but stated that it might be larger. These estimates are much higher than the chloride estimates and the reason is likely the same as stated earlier, i.e., that the two methods measure recharge over different periods which may have different weather and vegetation cover.

\subsubsection{Computer Modeling}

Computer models of water flow in soils encapsulate knowledge of important hydrologic processes. Such models are used to study questions related to waste disposal and climate change (known as "what if" questions). The more complex models require many parameters to operate; for many sites, only limited and surrogate data are available for estimating parameters. Despite this limitation, models can be used to estimate recharge rates for a variety of soil type/land use combinations.

Several modeling studies of recharge at the Hanford Site have occurred, including Gee and Kirkham (1984), Fayer et al. (1986), DOE (1987), Dudziak (1988), Gee et al. (1988), Jones (1989), Bauer and Vaccaro (1990), and Fayer et al. (1992). Most of these studies used the UNSAT-H computer code (Fayer and Jones 1990) or one of its predecessors. These studies combined have shown the importance of site-specific soil hydraulic properties, vegetation, and weather.

Appendix B describes a series of simulation studies of 12 combinations of soil type and vegetation/land use categories. The long-term average rates varied from 0.7 to $17.3 \mathrm{~mm} / \mathrm{yr}$, and the annual rates varied from 0.05 to $85.2 \mathrm{~mm} / \mathrm{yr}$. These variations reflect differences in soil type and vegetation as well as year-to-year weather variations. 


\subsection{Estimated Recharge Rates}

The strategy for identifying and mapping the distribution of estimated recharge rates at the Hanford Site is to match soil type (Figure 2.3) and vegetation/land use categories (Figure 2.4) with measured or estimated recharge rates. There are far fewer measurements than number of combinations of 15 soil types and 13 vegetation/land use categories. Furthermore, there is significant variability within the soil type and vegetation/land use categories. To make the estimation of recharge rates feasible, certain features were combined to reduce the number of combinations. Each combination was then compared with the available estimates of recharge. If a match existed, the estimated value was assigned to that combination. When a match did not exist, the combination was simulated with UNSAT-H using the procedure described in Appendix B.

\subsection{Assignment by Vegetation/Land Use Category}

Table 3.1 lists the categories of vegetation/land use that are found in Figure 2.4. Several of the categories were combined by cover type to reduce the number of combinations. Shrub-steppe on slopes and plains and hopsage/greasewood were assumed to behave similarly and were placed in the shrub cover type. Recovering shrub-steppe was assumed to have minimal shrub activity and was therefore combined with the bunchgrass on slopes category to form the bunchgrass cover type. Abandoned fields were assumed to be dominated with cheatgrass and were combined with that category to form the cheatgrass cover type. Finally, the disturbed/facilities category was called the no plants cover type.

For all 15 soil types, five cover types (riparian; agriculture; sand dunes; water; basalt outcrops) were assigned specific values that did not vary with soil type. The assignment of a recharge rate to each of these follows.

Riparian. This category includes plant communities growing on the banks of bodies of water such as streams, rivers, and sometimes lakes and ponds. The predominant location of this habitat is along the Columbia River, but such habitat also exists along the spring-fed streams emanating from Rattlesnake Mountain. No data exist on the recharge rates that may be occurring under such a land cover. Except for riverwash, no soil type has more than $0.5 \%$ of riparian cover. Because of its small areal extent and the lack of information, no attempt was made to assign a value of recharge to this cover . type. Any combination of soil type with riparian cover was treated as no value, i.e., no recharge was assigned to this category.

Agriculture. All agricultural areas in the land use coverage are outside the Hanford Site boundaries. Any combination with an agricultural area was treated as no value, i.e., no recharge was assigned to this category.

Sand Dunes. Sand dunes are a distinct soil type: Some dunes were identified by Hajek (1966), but the land use map (Downs et al. 1993) is much more recent. Therefore, whenever any soil type was coupled with the vegetation/land use category of sand dunes, the combination was treated as sand dune. A recharge rate of $55.4 \mathrm{~mm} / \mathrm{yr}$ was assigned to this combination. That value was derived from 8 years of observation of drainage from a medium to coarse sand with no vegetation (see Figure 2.5). 
Table 3.1. Categories of Vegetation/Land Use at the Hanford Site (from Downs et al. 1993) and Associated Cover Type

\begin{tabular}{|c|l|c||}
\hline Index & \multicolumn{1}{|c|}{ Vegetation/Land Use Category } & Cover Type \\
\hline \hline 1 & Shrub-steppe on slopes & Shrub \\
\hline 2 & $\begin{array}{l}\text { Shrub-steppe on the Columbia River Plain/ } \\
\text { Uplands }\end{array}$ & Shrub \\
\hline 3 & $\begin{array}{l}\text { Recovering shrub-steppe on the Columbia River } \\
\text { Plain/Uplands }\end{array}$ & Bunchgrass \\
\hline 4 & Bunchgrasses on slopes & Bunchgrass \\
\hline 5 & Hopsage/Greasewood & Shrub \\
\hline 6 & Cheatgrass & Cheatgrass \\
\hline 7 & Abandoned fields & Cheatgrass \\
\hline 8 & Riparian & Riparian \\
\hline 9 & Agricultural areas & Agriculture \\
\hline 10 & Sand dunes & Sand dunes \\
\hline 11 & Disturbed/Facilities & No plants \\
\hline 12 & Water & Water \\
\hline 13 & Basalt outcrops & Basalt outcrops \\
\hline
\end{tabular}

Water. This cover type refers to open bodies of water. Portions of some soil types occur in conjunction with open water, but no attempt was made to estimate recharge for these combinations. Therefore, all combinations of soil type with the land use type "water" were treated as no value, i.e., no recharge was assigned to this category.

Basalt Outcrops. This cover type occurs along mountain ridges and upper slopes and includes outcrops, scarps, and scree slopes. Measurements of recharge beneath this cover type were not available. As a surrogate, we used the measured drainage rate beneath gravel-covered lysimeters located at the FLTF (Gee et al. 1993). Under three years of ambient precipitation (184 mm/yr), this rate was $86.7 \mathrm{~mm} / \mathrm{yr}$. Under $3 \mathrm{x}$ normal precipitation $(480 \mathrm{~mm} / \mathrm{yr})$, this rate was $300 \mathrm{~mm} / \mathrm{yr}$. Stone et al. (1983) reported that precipitation along the Rattlesnake Mountain ridge averaged $240 \mathrm{~mm} / \mathrm{yr}$ from 1969 to 1980. At that precipitation rate, the associated drainage beneath a gravel cover was calculated to be $127.1 \mathrm{~mm} / \mathrm{yr}$ by scaling between the results of the FLTF lysimeters at ambient and $3 \mathrm{x}$ normal precipitation. The only soil type that appeared to be associated with outcrops and Rattlesnake Mountain ridge was Lickskillet silt loam. Therefore, that combination was assigned a recharge rate of $127.1 \mathrm{~mm} / \mathrm{yr}$.

Precipitation rates at the crests of Gable Mountain and Gable Butte are unknown. Because of their much smaller size and lower elevation relative to Rattlesnake Mountain, we assumed the precipitation rates at the crests of these features to be equivalent to precipitation recorded at the Hanford Meteorological Station (Stone et al. 1983). Therefore, for all soil types other than Lickskillet silt loam, the recharge rate of the basalt outcrops was assigned a value of $86.7 \mathrm{~mm} / \mathrm{yr}$. 


\subsection{Assignment by Soil Clasș}

The 15 soil types were combined into 5 soil classes: silt loam, sandy loam, loamy sand, sand with restrictive subsoil, and sand. Table 3.2 shows the soil type-soil class correlations. Each combination of soil class and the remaining vegetation/land use indexes was assigned an individual recharge rate. Estimates derived from lysimeter and water content measurements were used in preference to estimates from tracers and models. Whenever multiple estimates were available from tracer studies, the highest estimate was used. Whenever tracer and modeling estimates were available for vegetated sites, the tracer estimate was used. The soil descriptions are a composite from Kocher and Strahorn (1919), Hajek (1966), and USDA (1971).

\subsubsection{Silt Loam}

The silt loam class includes seven soil types. As a class, the silt loam was treated as the Warden silt loam when assigning rates. The individual soil types are described below, followed by the assignment of estimated recharge rates for this soil class.

\subsubsection{Soil Types}

Esquatzel Silt Loam. This deep silt loam formed in recent alluvium derived from loess and lake sediments. It may have developed in sediments eroded from the Warden and Ritzville silt loams.

Table 3.2. Soil Types at the Hanford Site (from Hajek 1966)

\begin{tabular}{|c|c|l|l||}
\hline Index & Symbol & \multicolumn{1}{|c|}{ Soil Type } & \multicolumn{1}{|c|}{ Soil Class } \\
\hline \hline 1 & $\mathrm{Ri}$ & Ritzville silt loam & Silt loam \\
\hline 2 & $\mathrm{Qy}$ & Rupert sand & Sand \\
\hline 3 & $\mathrm{He}$ & Hezel sand & Sand with restrictive layer \\
\hline 4 & $\mathrm{Kf}$ & Koehler sand & Sand with restrictive layer \\
\hline 5 & $\mathrm{Ba}$ & Burbank loamy sand & Loamy sand \\
\hline 6 & $\mathrm{E} 1$ & Ephrata sandy loam & Sandy loam \\
\hline 7 & Ls & Lickskillet silt loam & Silt loam \\
\hline 8 & $\mathrm{~Eb}$ & Ephrata stony loam & Sandy loam \\
\hline 9 & $\mathrm{Ki}$ & Kiona silt loam & Silt loam \\
\hline 10 & $\mathrm{Wa}$ & Warden silt loam & Silt loam \\
\hline 11 & $\mathrm{Sc}$ & Scootney stoney silt loam & Silt loam \\
\hline 12 & $\mathrm{P}$ & Pasco silt loam & Silt loam \\
\hline 13 & Qu & Esquatzel silt loam & Silt loam \\
\hline 14 & $\mathrm{Rv}$ & Riverwash & Sand \\
\hline 15 & $\mathrm{D}$ & Dunesand & Sand \\
\hline
\end{tabular}


Pasco Silt Loam. This poorly drained silt loam formed in recent alluvial material. Soil depth is greater than $150 \mathrm{~cm}$.

Ritzville Silt Loam. This soil developed under bunchgrass in silty wind-laid deposits mixed with small amounts of volcanic ash. Depths are characteristically greater than $150 \mathrm{~cm}$, but basalt bedrock may be as shallow as $75 \mathrm{~cm}$.

Warden Silt Loam. This silt loam is typically deeper than $150 \mathrm{~cm}$. The subsoil is strongly calcareous at about $51 \mathrm{~cm}$. This soil grades to Ritzville silt loam at the higher elevations.

Lickskillet Silt Loam. This silt loam occurs at the ridge tops of the Rattlesnakes Hills and at slopes above the 762-m elevation. This soil is shallow over bedrock and contains numerous basalt fragments throughout the profile.

Kiona Silt Loam. This silt loam develops on steep slopes and ridges. Below $10 \mathrm{~cm}$, this soil contains basalt fragments $30 \mathrm{~cm}$ or more in diameter. The surface layer contains basalt fragments, and basalt rock outcrops are present.

Scootney Stony Silt Loam. This silt loam is usually confined to floors of narrow draws, or small fanshaped areas where the draws open onto plains, along the north slope of the Rattlesnake Hills. This soil contains numerous basaltic boulders. and fragments and rests on fragments at depths of 50 to $75 \mathrm{~cm}$. Bedrock can occur anywhere from 75 to $150 \mathrm{~cm}$ below the surface.

\subsubsection{Estimated Recharge Rates}

Shrub. A rate of $3.4 \mathrm{~mm} / \mathrm{yr}$ was assigned to this cover type based on a report by Prych (1994 in press) in which $\mathrm{Cl}-36$ data were used to determine recharge for Ritzville or Warden silt loam under a shrub-steppe cover.

Bunchgrass. A rate of $3.4 \mathrm{~mm} / \mathrm{yr}$ was assigned to this cover type based on the Cl-36 data reported by Prych (1994 in press) for shrubs. Link et al. (1990) reported water content data that implied recharge beneath bunchgrass was $3.1 \mathrm{~mm} / \mathrm{yr}$ greater than under nearby shrub-steppe. Combined with the Prych (1994 in press) estimate of $3.4 \mathrm{~mm} / \mathrm{yr}$ recharge under shrub-steppe, the Link data imply recharge beneath bunchgrass was $6.5 \mathrm{~mm} / \mathrm{yr}$. However, this calculation was not considered strong enough to justify assigning the higher rate.

Cheatgrass. A rate of $4.4 \mathrm{~mm} / \mathrm{yr}$ was assigned to this cover type based on the results of simulations reported in Appendix B for the period from 1958 to 1992.

No Plants. A rate of $6.8 \mathrm{~mm} / \mathrm{yr}$ was assigned to this cover type based on the results of simulations reported in Appendix B for the period from 1958 to 1992.

\subsubsection{Sandy Loam}

The sandy loam class includes two soil types. As a class, the sandy loam was treated as the Ephrata sandy loam when assigning rates. The individual soil types are described below, followed by the assignment of estimated recharge rates for this soil class. 


\subsubsection{Soil Types}

Ephrata Sandy Loam. This fine sandy loam soil rests on waterworn gravel embedded in sand at $150 \mathrm{~cm}$. In some locations, the soil may rest on gravel, cobbles, and boulders embedded in silt.

Ephrata Stony Loam. This soil is similar to the Ephrata sandy loam but contains many hummocky ridges made up of debris released from the melting glacial ice. The soil may be as shallow as $90 \mathrm{~cm}$.

\subsubsection{Estimated Recharge Rates}

Shrub. A rate of $2.6 \mathrm{~mm} / \mathrm{yr}$ was assigned to this cover type based on a report by Prych (1994 in press) in which Cl-36 data were used to determine recharge for Ephrata sandy loam (or possibly Burbank loamy sand) under a shrub-steppe cover.

Bunchgrass. A rate of $2.6 \mathrm{~mm} / \mathrm{yr}$ was assigned to this cover type based on the $\mathrm{Cl}-36$ data reported by Prych (1994 in press) for shrubs. The simulation results in Appendix B showed the estimated rate to be $1.0 \mathrm{~mm} / \mathrm{yr}$ from 1958 to 1992 , but the tracer measurement was considered to be more representative of vegetated sites.

Cheatgrass. A rate of $4.9 \mathrm{~mm} / \mathrm{yr}$ was assigned to this cover type based on the results of simulations reported in Appendix B for the period from 1958 to 1992.

No Plants. A rate of $17.3 \mathrm{~mm} / \mathrm{yr}$ was assigned to this cover type based on the results of simulations reported in Appendix B for the period from 1958 to 1992.

\subsubsection{Loamy Sand}

The loamy sand class consists of one soil type, the Burbank loamy sand. This soil type is described below, followed by the assignment of estimated recharge rates for this soil class.

\subsubsection{Soil Types}

Burbank Loamy Sand. The texture of this soil ranges from sand to loamy fine sand, is typically 41 to $75 \mathrm{~cm}$ thick, and rests on sandy gravel that ranges from 20 to $80 \%$ gravel.

\subsubsection{Estimated Recharge Rates}

Shrub. A rate of $2.6 \mathrm{~mm} / \mathrm{yr}$ was assigned to this cover type based on a report by Prych (1994 in press) in which $\mathrm{Cl}-36$ data were used to determine recharge for Burbank loamy sand (or possibly Ephrata sandy loam) under a shrub-steppe cover.

Bunchgrass. A rate of $2.6 \mathrm{~mm} / \mathrm{yr}$ was assigned to this cover type based on the $\mathrm{Cl}-36$ data reported by Prych (1994 in press) for shrubs.

Cheatgrass. A rate of $2.6 \mathrm{~mm} / \mathrm{yr}$ was assigned to this cover type based on the $\mathrm{Cl}-36$ data reported by Prych (1994 in press) for shrubs. The simulation results in Appendix B showed the estimated rate to be $2.5 \mathrm{~mm} / \mathrm{yr}$ from 1958 to 1992 , but the tracer measurement was considered to be more representative of vegetated sites.

No Plants. A rate of $4.4 \mathrm{~mm} / \mathrm{yr}$ was assigned to this cover type based on the results of simulations reported in Appendix B for the period from 1958 to 1992. 


\subsubsection{Sand With Restrictive Layer}

The sand with restrictive layer class includes two soil types. As a class, the sand with restrictive layer was treated as the Hezel sand when assigning rates. The individual soil types are described below, followed by the assignment of estimated recharge rates for this soil class.

\subsubsection{Soil Types}

Hezel Sand. This sand formed in wind-blown sands and mantled lake-laid sediments and has a strongly calcareous silt loam subsoil within $102 \mathrm{~cm}$ of the surface. Except for the silt subsoil, the Hezel sand is similar to the Rupert sand.

Koehler Sand. This sand is similar to other sands at the Hanford Site, having formed in a wind-blown sand mantle. It differs from the other sands, however, because it has a lime-silica cemented hardpan at $45 \mathrm{~cm}$.

\subsubsection{Estimated Recharge Rates}

Shrub. A rate of $2.6 \mathrm{~mm} / \mathrm{yr}$ was assigned to this cover type based on a report by Prych (1994 in press) in which Cl-36 data were used to determine recharge for Burbank loamy sand (or possibly Ephrata sandy loam) under a shrub-steppe cover. Estimates for the Hezel sand were not available.

Bunchgrass. A rate of $2.6 \mathrm{~mm} / \mathrm{yr}$ was assigned to this cover type based on the Cl-36 data reported by Prych (1994 in press) for shrubs. The simulation results in Appendix B showed the estimated rate to be $0.7 \mathrm{~mm} / \mathrm{yr}$ from 1970 to 1992 , but the tracer measurement was considered to be more representative of vegetated sites.

Cheatgrass. A rate of $3.4 \mathrm{~mm} / \mathrm{yr}$ was assigned to this cover type based on the results of simulations reported in Appendix B for the period from 1958 to 1992.

No Plants. A rate of $6.4 \mathrm{~mm} / \mathrm{yr}$ was assigned to this cover type based on the results of simulations reported in Appendix B for the period from 1958 to 1992.

\subsubsection{Sand}

The sand class includes three soil types. As a class, the sand was treated as the Rupert sand when assigning rates. The individual soil types are described below, followed by the assignment of estimated recharge rates for this soil class.

\subsubsection{Soil Types}

Rupert Sand. This deep sand formed in coarse alluvial deposits that were mantled by wind-blown sand. The relief is characterized by hummocky terraces and dune-like ridges. The USDA (1971) counterpart is likely the Quincy sand.

Riverwash. This soil type represents deposits of sand, gravel, and boulders along the Columbia River. These soils are wet and periodically flooded.

Dunesand. This soil type represents areas with hills or ridges of sand-sized particles drifted and piled by wind. Soil depth exceeds $150 \mathrm{~cm}$; soil horizons have not developed. 


\subsubsection{Estimated Recharge Rates}

Shrub. A rate of $8.6 \mathrm{~mm} / \mathrm{yr}$ was assigned to this cover type based on the results of simulations reported in Appendix B for the period from 1966 to 1992.

Bunchgrass. A rate of $11.3 \mathrm{~mm} / \mathrm{yr}$ was assigned to this cover type based on the results of simulations reported in Appendix B for the period from 1962 to 1992.

Cheatgrass. A rate of $25.4 \mathrm{~mm} / \mathrm{yr}$ was assigned to this cover type based on subsurface water contents measured at the Grass Site from January 1983 to June 1991.

No Plants. A rate of $55.4 \mathrm{~mm} / \mathrm{yr}$ was assigned to this cover type based on drainage measured in the South Caisson of the Buried Waste Test Facility from July 1984 to June 1993. 


\subsection{Results and Discussion}

The estimated recharge rates from Section 3.0 were used to create a map of recharge rates and to calculate recharge volumes. This Section describes the recharge map, summarizes the effects of soil type and vegetation, compares the recharge volumes to other inputs to the ground water, and highlights selected issues that contribute to the uncertainty of the estimates.

\subsection{Recharge Map}

Table 4.1 summarizes the assignment of recharge rate estimates in Section 3.0. Figure 4.1 shows the map of estimated recharge rates that was constructed from the information in Table 4.1 and Figures 2.3 and 2.4. The reader is cautioned that the map provides areal, not site-specific, estimates of recharge. Recharge is affected by processes at scales that are an order of magnitude or more smaller than the supporting data used to generate the recharge map. Therefore, readers wishing to have an accurate site-specific estimate of recharge should consider using site-specific information on soils and vegetation.

Figure 4.1 does not reflect historical recharge rates; rather, the map reveals the distribution of recharge that was estimated using the current climate and vegetation/land use patterns. Exactly when these estimated rates will impact the water table depends on the travel time through the unsaturated zone, which varies in thickness across the Site. A map of historical rates prior to farming and Hanford operations could be constructed by assuming the Site was covered with shrub-steppe. To estimate recharge rates at the water table during the period that includes surface disturbances such as farming and Hanford operations, one would need to know the nature of the disturbance, estimate the recharge rate, and determine whether the changed recharge rate would impact the water table in the period of interest. That would be a function of the new estimate of the recharge rate, and the thickness and water content of the unsaturated zone.

\subsection{Soil Type and Vegetation Effects}

The distribution of estimated recharge rates in Figure 4.1 shows clearly the influence of both soil type and vegetation. The silt loams in the Rattlesnake Hills have low rates. The outline of the 1984 burn is clearly visible in the southeast quadrant of the Site. The disturbed areas and sand dunes have rates significantly higher than their surroundings.

\subsubsection{Whole Site}

The portion of the Hanford Site on the north side of the Columbia River is not considered in the ground-water model, so was not considered for this report. Therefore, references to the whole Site are references to the Site bounded by the Columbia River to the north and east. Table 4.2 lists the area of each combination of soil type and vegetation/land use for the whole Site. By soil type, the silt loam soils $(28 \%)$, Rupert sand (33\%), and Burbank loamy sand (20\%) occupy the largest area. By vegetation category, the shrub-steppe $(30 \%)$, recovering shrub-steppe $(33 \%)$, and bunchgrass (15\%) categories occupy the largest area.

Table 4.3 shows the annual volume of estimated recharge occurring under each combination of soil type and vegetation/land use category. This table was created by multiplying the estimated rates 
Table 4.1. Estimated Recharge Rates at the Hanford Site for Each Combination of Soil Type and Vegetation/Land Use. The recharge estimate for each combination is based on either measurements, modeling, or inferences from other combinations, as explained in Section 3.0.

\begin{tabular}{|c|c|c|c|c|c|c|c|c|c|}
\hline \multicolumn{2}{|r|}{ Vegetation/Land Use } & \multirow{2}{*}{\multicolumn{8}{|c|}{$\frac{\text { Recharge Rates }(\mathrm{mm} / \mathrm{yr})}{\text { Soil Types }}$}} \\
\hline \multirow[b]{2}{*}{ Index } & \multirow[b]{2}{*}{ Description } & & & & & & & & \\
\hline & & $\mathbf{R i}$ & $\mathbf{R p}$ & $\mathrm{He}$ & $\mathrm{Kf}$ & $\mathrm{Ba}$ & E1 & Ls & $\mathrm{Eb}$ \\
\hline 1 & Shrub-steppe on slopes & 3.4 & 8.6 & 2.6 & 2.6 & 2.6 & 2.6 & 3.4 & 2.6 \\
\hline 2 & Shrub-steppe on plain/uplands & 3.4 & 8.6 & 2.6 & 2.6 & 2.6 & 2.6 & 3.4 & 2.6 \\
\hline 3 & Recovering shrub-steppe on plain/uplands & 3.4 & 11.3 & 2.6 & 2.6 & 2.6 & 2.6 & 3.4 & 2.6 \\
\hline 4 & Bunchgrass on slopes & 3.4 & 11.3 & 2.6 & 2.6 & 2.6 & 2.6 & 3.4 & 2.6 \\
\hline 5 & Hopsage/greasewood & 3.4 & 8.6 & 2.6 & 2.6 & 2.6 & 2.6 & 3.4 & 2.6 \\
\hline 6 & Cheatgrass & 4.8 & 25.4 & 3.4 & 3.4 & 2.6 & 4.9 & 4.8 & 4.9 \\
\hline 7 & Abandoned fields & 4.8 & 25.4 & 3.4 & 3.4 & 2.6 & 4.9 & 4.8 & 4.9 \\
\hline 8 & Riparian & 0.0 & 0.0 & 0.0 & 0.0 & 0.0 & 0.0 & 0.0 & 0.0 \\
\hline 9 & Agricultural areas & 0.0 & 0.0 & 0.0 & 0.0 & 0.0 & 0.0 & 0.0 & 0.0 \\
\hline 10 & Sand dunes & 55.4 & 55.4 & 55.4 & 55.4 & 55.4 & 55.4 & 55.4 & 55.4 \\
\hline 11 & Disturbed/Facilities & 6.8 & 55.4 & 6.4 & 6.4 & 4.4 & 17.3 & 6.8 & 17.3 \\
\hline 12 & Water & 0.0 & 0.0 & 0.0 & 0.0 & 0.0 & 0.0 & 0.0 & 0.0 \\
\hline 13 & Basalt outcrops & 86.7 & 86.7 & 86.7 & 86.7 & 86.7 & 86.7 & 127.1 & 86.7 \\
\hline
\end{tabular}

\begin{tabular}{|c|c|c|c|c|c|c|c|c|}
\hline \multirow[b]{3}{*}{ Index } & Vegetation/Land Use & & & Rechar & Rates & $\mathrm{n} / \mathrm{yr})$ & & \\
\hline & \multirow[b]{2}{*}{ Description } & \multicolumn{7}{|c|}{ Soil Types } \\
\hline & & $\mathrm{Ki}$ & Wa & Sc & $\mathbf{P}$ & Qu & Rv & D \\
\hline 1 & Shrub-steppe on slopes & 3.4 & 3.4 & 3.4 & 3.4 & 3.4 & 8.6 & 8.6 \\
\hline 2 & Shrub-steppe on plain/uplands & 3.4 & 3.4 & 3.4 & 3.4 & 3.4 & 8.6 & 8.6 \\
\hline 3 & Recovering shrub-steppe on plain/uplands & 3.4 & 3.4 & 3.4 & 3.4 & 3.4 & 11.3 & 11.3 \\
\hline 4 & Bunchgrass on slopes & 3.4 & 3.4 & 3.4 & 3.4 & 3.4 & 11.3 & 11.3 \\
\hline 5 & Hopsage/greasewood & 3.4 & 3.4 & 3.4 & 3.4 & 3.4 & 8.6 & 8.6 \\
\hline 6 & Cheatgrass & 4.8 & 4.8 & 4.8 & 4.8 & 4.8 & 25.4 & 25.4 \\
\hline 7 & Abandoned fields & 4.8 & 4.8 & 4.8 & 4.8 & 4.8 & 25.4 & 25.4 \\
\hline 8 & Riparian & 0.0 & 0.0 & 0.0 & 0.0 & 0.0 & 0.0 & 0.0 \\
\hline 9 & Agricultural areas & 0.0 & 0.0 & 0.0 & 0.0 & 0.0 & 0.0 & 0.0 \\
\hline 10 & Sand dunes & 55.4 & 55.4 & 55.4 & 55.4 & 55.4 & 55.4 & 55.4 \\
\hline 11 & Disturbed/Facilities & 6.8 & 6.8 & 6.8 & 6.8 & 6.8 & 55.4 & 55.4 \\
\hline 12 & Water & 0.0 & 0.0 & 0.0 & 0.0 & 0.0 & 0.0 & 0.0 \\
\hline 13 & Basalt outcrops & 86.7 & 86.7 & 86.7 & 86.7 & 86.7 & 86.7 & 86.7 \\
\hline
\end{tabular}




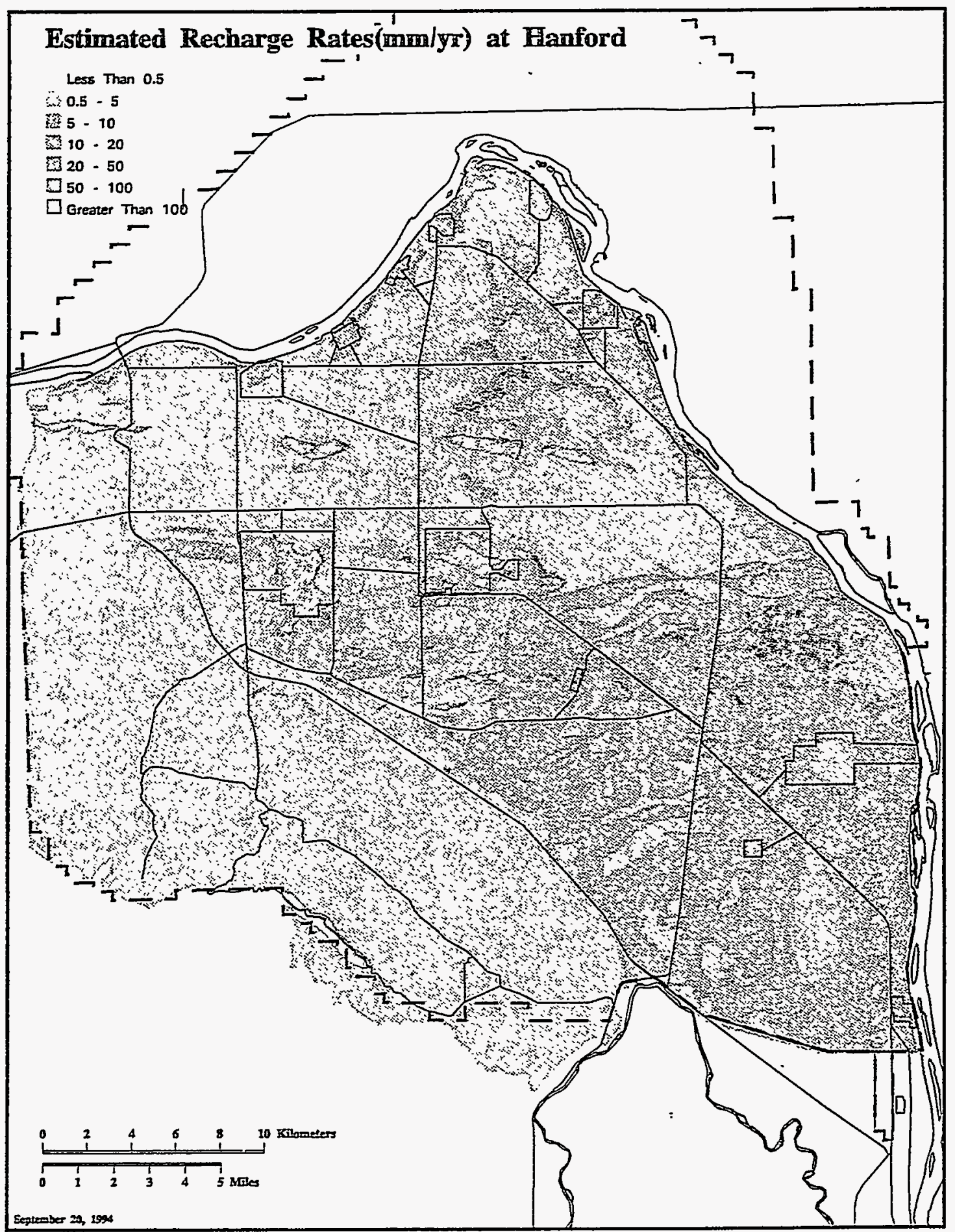

Figure 4.1. Distribution of Estimated Recharge Rates at the Hanford Site. The area represented by each image cell is $2500 \mathrm{~m}^{2}$. 
Table 4.2. Area of Each Combination of Soil Type and Vegetation/Land Use Within the Boundaries of the Whole Site

\begin{tabular}{|c|c|c|c|c|c|c|c|c|c|c|c|c|c|c|c|c|c|c|}
\hline \multicolumn{2}{|r|}{ Vegetation/Land Use } & \multicolumn{15}{|c|}{ Area $\left(\mathrm{km}^{2}\right)$} & \multirow{3}{*}{$\begin{array}{l}\text { Area per } \\
\text { Veg. } \\
\text { Type } \\
\left(\mathrm{km}^{2}\right)\end{array}$} & \multirow{3}{*}{$\begin{array}{c}\text { Percent } \\
\text { of Tota } \\
\text { Area }\end{array}$} \\
\hline & \multirow[b]{2}{*}{ Description } & \multicolumn{15}{|c|}{ Soil Types } & & \\
\hline Index & & $\mathrm{Ri}$ & $\mathrm{Rp}$ & $\mathrm{He}$ & Kf & $\mathrm{Ba}$ & E1 & Ls & Eb & $\mathbf{K i}$ & Wa & Sc & $\mathbf{P}$ & Qu & Rv & $\mathrm{D}$ & & \\
\hline 1 & Shrub-steppe on slopes & 11.8 & 0.1 & & & 0.0 & & 23.8 & & 2.5 & 9.4 & 0.0 & & 0.2 & & & 47.9 & 4.3 \\
\hline 2 & Shrub-steppe on plain/uplands & 5.5 & 70.4 & 16.5 & 2.8 & 101.1 & 36.3 & & 6.2 & 7.4 & 33.5 & 0.2 & 0.3 & 7.4 & 1.0 & & 288.7 & 26.1 \\
\hline 3 & Recovering shrub-steppe on plain/uplands & 0.3 & 233.2 & 15.9 & 1.6 & 61.7 & 19.9 & & 1.0 & 2.3 & 7.9 & 0.0 & 0.2 & 9.0 & & 9.0 & 362.1 & 32.7 \\
\hline 4 & Bunchgrass on slopes & 47.4 & & 1.7 & 0.0 & 1.2 & 0.9 & 19.8 & & 12.5 & 71.1 & 8.1 & & 1.2 & & & 163.8 & 14.8 \\
\hline 5 & Hopsage/greasewood & & & 1.0 & & 0.2 & 0.0 & & & 0.1 & 0.0 & & & 0.6 & & & 1.9 & 0.2 \\
\hline 6 & Cheatgrass & & 16.1 & 9.4 & 0.2 & 23.4 & 40.6 & & 6.8 & 0.3 & 6.8 & 1.1 & 0.6 & 7.9 & 1.4 & & 114.6 & 10.4 \\
\hline 7 & Abandoned fields & 1.4 & 9.4 & & & 20.5 & 4.5 & 0.4 & & 0.0 & 2.6 & & 0.6 & & 0.6 & & 40.0 & 3.6 \\
\hline 8 & Riparian & 0.0 & 0.9 & 0.1 & & 0.2 & 0.5 & 0.2 & 0.3 & 0.0 & 0.1 & 0.0 & 0.1 & 0.0 & 1.2 & & 3.6 & 0.3 \\
\hline 9 & Agricultural areas & 0.0 & & & & & & 0.0 & & 0.0 & 0.0 & & & & & & 0.1 & 0.0 \\
\hline 10 & Sand dunes & & 12.9 & 1.5 & & 0.8 & 0.0 & & & & & & & 0.1 & 0.0 & 12.9 & 28.2 & 2.5 \\
\hline 11 & Disturbed/Facilities & 0.1 & 21.5 & 0.3 & 0.0 & 9.2 & 6.1 & 0.1 & 4.8 & 0.2 & 0.1 & & 0.0 & 0.2 & 0.2 & & 42.7 & 3.9 \\
\hline 12 & Water & & 0.7 & & & 0.2 & 0.3 & & 0.3 & & & & & & 0.5 & 0.0 & 2.0 & 0.2 \\
\hline 13 & Basalt outcrops & & 0.0 & & & 0.2 & 0.7 & 2.9 & 6.1 & & & & & & & & 10.1 & 0.9 \\
\hline & Total Area $\left(\mathrm{km}^{2}\right)$ per Soil Type $=$ & 66.5 & 365.2 & 46.4 & 4.6 & 218.9 & 109.9 & 47.2 & 25.6 & 25.2 & 131.5 & 9.5 & 1.8 & 26.6 & 4.8 & 21.9 & 1105.6 & \\
\hline & Percent of Total Area $=$ & 6.0 & 33.0 & 4.2 & 0.4 & 19.8 & 9.9 & 4.3 & 2.3 & 2.3 & 11.9 & 0.9 & 0.2 & 2.4 & 0.4 & 2.0 & & \\
\hline
\end{tabular}


Table 4.3. Annual Recharge Volume for Each Combination of Soil Type and Vegetation/Land Use Within the Boundaries of the Whole Site. The recharge estimate for each combination is based on either measurements, modeling, or inferences from other combinations, as explained in Section 3.0.

\begin{tabular}{|c|c|c|c|c|c|c|c|c|c|c|c|c|c|c|c|c|c|c|}
\hline \multicolumn{2}{|r|}{ Vegetation/Land Use } & \multicolumn{15}{|c|}{ Annual Recharge Volume (L) } & \multirow{3}{*}{$\begin{array}{l}\text { Vol. per } \\
\text { Veg. Type } \\
\text { (L). }\end{array}$} & \multirow{3}{*}{$\begin{array}{l}\text { Percent } \\
\text { of Total } \\
\text { Volume }\end{array}$} \\
\hline & \multirow[b]{2}{*}{ Description } & \multicolumn{15}{|c|}{ Soil Types } & & \\
\hline Index & & $\mathbf{R i}$ & $\mathbf{R p}$ & $\mathrm{He}$ & $\mathbf{K f}$ & Ba & El & Ls & Eb & $\mathbf{K i}$ & wa & sc & $\mathbf{p}$ & Qu & Rv & D & & \\
\hline 1 & Shrub-steppe on slopes & $4.0 E+07$ & $9.7 E+05$ & 0.0 & 0.0 & $1.0 \mathrm{E}+05$ & 0.0 & $8.1 E+07$ & 0.0 & $8.4 \mathrm{E}+06$ & $3.2 \mathrm{E}+07$ & $1.6 \mathrm{E}+05$ & 0.0 & $5.8 \mathrm{E}+05$ & 0.0 & 0.0 & $1.6 \mathrm{E}+08$ & 1.6 \\
\hline 2 & Shrub-steppe on plain/uplands & $1.9 \mathrm{E}+07$ & $6.1 \mathrm{E}+08$ & $4.3 E+07$ & $7.2 \mathrm{E}+06$ & $2.6 \mathrm{E}+08$ & $9.4 E+07$ & 0.0 & $1.6 \mathrm{E}+07$ & $2.5 E+07$ & $1.1 E+08$ & $7.8 \mathrm{E}+05$ & $1.2 E+06$ & $2.5 \mathrm{E}+07$ & $8.5 \mathrm{E}+06$ & 0.0 & $1.2 E+09$ & 12.0 \\
\hline 3 & $\begin{array}{l}\text { Recovering shrub-steppe on } \\
\text { plain/uplands }\end{array}$ & $1.1 \mathrm{E}+06$ & $2.6 \mathrm{E}+09$ & 4.1E+07 & $4.1 \mathrm{E}+06$ & $1.6 \mathrm{E}+08$ & $5.2 E+07$ & 0.0 & $2.6 \mathrm{E}+06$ & $7.9 E+06$ & $2.7 E+07$ & $4.3 E+04$ & $6.6 \mathrm{E}+0 \mathrm{~S}$ & $3.1 E+07$ & 0.0 & $1.0 \mathrm{E}+08$ & $3.1 E+09$ & 30.0 \\
\hline 4 & Bunchgrass on slopes & $1.6 \mathrm{E}+08$ & 0.0 & $4.4 \mathrm{E}+06$ & $8.5 \mathrm{E}+04$ & $.3 .0 \mathrm{E}+06$ & $2.2 \mathrm{E}+06$ & $6.7 E+07$ & 0.0 & $4.2 \mathrm{E}+07$ & $2.4 \mathrm{E}+08$ & $2.7 E+07$ & 0.0 & $4.1 \mathrm{E}+06$ & 0.0 & 0.0 & $5.5 E+08$ & 5.4 \\
\hline 5 & Hopsage/greasewood & 0.0 & 0.0 & $2.7 \mathrm{E}+06$ & 0.0 & $6.0 \mathrm{E}+05$ & $3.9 \mathrm{E}+04$ & 0.0 & 0.0 & $2.5 \mathrm{E}+05$ & $4.3 \mathrm{E}+04$ & 0.0 & 0.0 & $1.9 \mathrm{E}+06$ & 0.0 & 0.0 & $5.6 \mathrm{E}+06$ & 0.1 \\
\hline 6 & Cheatgrass & 0.0 & 4.1E+08 & $3.2 E+07$ & $8.2 \mathrm{E}+0 \mathrm{~S}$ & $6.1 E+07$ & $2.0 \mathrm{E}+08$ & 0.0 & $3.4 E+07$ & $1.3 E+06$ & $3.3 \mathrm{E}+07$ & $5.3 \mathrm{E}+06$ & $2.7 \mathrm{E}+06$ & $3.8 \mathrm{E}+07$ & $3.5 \mathrm{E}+07$ & 0.0 & $8.5 E+08$ & 8.3 \\
\hline 7 & Abandoned fields & $6.6 \mathrm{E}+06$ & $2.4 \mathrm{E}+08$ & 0.0 & 0.0 & $5.3 E+07$ & $2.2 \mathrm{E}+07$ & $1.8 \mathrm{E}+06$ & 0.0 & $1.2 E+04$ & $1.3 \mathrm{E}+07$ & 0.0 & $2.7 E+06$ & 0.0 & $1.5 E+07$ & 0.0 & $3.5 E+08$ & 3.5 \\
\hline 8 & Riparian & 0.0 & 0.0 & 0.0 & 0.0 & 0.0 & 0.0 & 0.0 & 0.0 & 0.0 & 0.0 & 0.0 & 0.0 & 0.0 & 0.0 & 0.0 & 0.0 & 0.0 \\
\hline 9 & Agricultural areas & 0.0 & 0.0 & 0.0 & 0.0 & 0.0 & 0.0 & 0.0 & 0.0 & 0.0 & 0.0 & 0.0 & 0.0 & 0.0 & 0.0 & 0.0 & 0.0 & 0.0 \\
\hline 10 & Sand dunes & 0.0 & $7.1 \mathrm{E}+08$ & $8.2 \mathrm{E}+07$ & 0.0 & $4.7 E+07$ & $1.2 E+\infty 6$ & 0.0 & 0.0 & 0.0 & 0.0 & 0.0 & 0.0 & $3.0 \mathrm{E}+06$ & 4.2E+05 & $7.1 E+08$ & $1.6 \mathrm{E}+09$ & 15.3 \\
\hline 11 & Disturbed/Facilitics & $4.6 \mathrm{E}+05$ & $1.2 \mathrm{E}+09$ & $1.8 \mathrm{E}+06$ & $2.4 \mathrm{E}+05$ & $4.1 \mathrm{E}+07$ & $1.1 \mathrm{E}+08$ & $4.8 \mathrm{E}+0 \mathrm{~s}$ & $8.2 E+07$ & $1.1 \mathrm{E}+06$ & $8.7 \mathrm{E}+05$ & 0.0 & $1.9 \mathrm{E}+05$ & $1.6 \mathrm{E}+06$ & $1.0 \mathrm{E}+07$ & 0.0 & $1.4 \mathrm{E}+09$ & 14.1 \\
\hline 12 & Water & 0.0 & 0.0 & 0.0 & 0.0 & 0.0 & 0.0 & 0.0 & 0.0 & 0.0 & 0.0 & 0.0 & 0.0 & 0.0 & 0.0 & 0.0 & 0.0 & 0.0 \\
\hline 13 & Basalt outcrops & 0.0 & $3.3 \mathrm{E}+06$ & 0.0 & 0.0 & $2.1 E+07$ & $6.4 \mathrm{E}+07$ & $3.7 \mathrm{E}+08$ & $5.3 E+08$ & 0.0 & 0.0 & 0.0 & 0.0 & 0.0 & 0.0 & 0.0 & $9.9 \mathrm{E}+08$ & 9.7 \\
\hline & Annual Volume (L) per Soil Type $=$ & $2.3 E+08$ & $5.8 \mathrm{E}+09$ & $2.1 \mathrm{E}+08$ & $1.2 E+07$ & $6.5 E+08$ & $5.4 \mathrm{E}+08$ & $5.2 E+08$ & $6.7 \mathrm{E}+08$ & $8.7 E+07$ & $4.6 \mathrm{E}+08$ & $3.4 E+07$ & $7.5 \mathrm{E}+06$ & $1.0 \mathrm{E}+08$ & $6.9 E+07$ & $8.2 \mathrm{E}+08$ & $1.0 \mathrm{E}+10$ & \\
\hline & Percent of Total Volume $=$ & 2.2 & 56.8 & 2.0 & 0.1 & 6.4 & 5.3 & 5.1 & 6.5 & 0.8 & 4.5 & 0.3 & 0.1 & 1.0 & 0.7 & 8.0 & & \\
\hline
\end{tabular}


in Table 4.1 by the corresponding area in Table 4.2. Table 4.3 shows that, by soil type, Rupert sand is the largest contributor of recharge at $57 \%$. By vegetation category, the recovering shrub-steppe (30\%), sand dunes (15\%), and disturbed areas (14\%) contribute the largest amount of recharge water.

\subsubsection{Potential Future Site}

The Arid Lands Ecology Reserve may eventually be separated from the Hanford Site such that the new Site boundary could become Highway 240 . In recognition of this change, Table 4.4 was prepared to show the area of each combination of soil type and vegetation/land use for this possible future Hanford Site, bounded on the west by Highway 240 and on the east by the Columbia River. Through serendipity, Highway 240 more or less runs along the western edge of the domain of the ground-water model, so recharge estimates for this new Site area apply directly to the model domain. By soil type, the Rupert sand (47\%), Burbank loamy sand (28\%), and Ephrata sandy loam (12\%) occupy the largest area. By vegetation category, the shrub-steppe (30\%), recovering shrub-steppe (45\%), and cheatgrass (10\%) categories occupy the largest area.

Table 4.5 shows the annual volume of estimated recharge occurring under each combination of soil type and vegetation/land use category. This table was created by multiplying the estimated rates in Table 4.1 by the corresponding area in Table 4.4. Table 4.5 shows that, by soil type, Rupert sand is the largest contributor of recharge at $68 \%$, with sand dunes a distant second at $10 \%$ (despite its small contributing area). By vegetation category, the recovering shrub-steppe (35\%), sand dunes $(18 \%)$, and disturbed areas $(17 \%)$ contribute the largest amount of recharge water.

\subsection{Comparison to Other Ground-Water Inputs}

Previous estimates of the distribution of recharge rates were used to calculate their associated recharge volumes for the potential future Site. The Jacobson and Freshley (1990) map resulted in an annual recharge volume estimate of $1.73 \times 1010 \mathrm{~L}$. The Bauer and Vaccaro (1990) map resulted in a recharge volume estimate of $6.63 \times 10^{9} \mathrm{~L}$. Based on the data in Table 4.5 , the total quantity of water contributed to the ground water from natural recharge is $8.47 \times 10^{9} \mathrm{~L}$. This quantity represents $28 \%$ more than the amount determined from the Bauer and Vaccaro (1990) recharge estimates and $49 \%$ of the amount determined from the Jacobson and Freshley (1990) recharge rate estimates.

The CFEST computer code uses two boundaries to represent the ground-water input from the Rattlesnake Hills. One boundary, located near the outlet of Dry Creek, is treated as a flux boundary. Jacobson and Freshley (1990) specified this boundary flux as $4.86 \times 10^{8} \mathrm{~L} / \mathrm{yr}$. The second boundary is located near Upper Cold Creek. This boundary is treated as a held head boundary. With this type of boundary, the flux entering the model domain is a function of the conditions of each simulation. Jacobson and Freshley (1990) estimated that the amount was $3.21 \times 10^{9} \mathrm{~L} / \mathrm{yr}$. The total flux at the two boundaries was $3.70 \times 10^{9} \mathrm{~L} / \mathrm{yr}$. The USGS (1987) estimated $8.93 \times 10^{8} \mathrm{~L} / \mathrm{yr}$ as the combined input from both runoff and ground-water flow from the higher elevations. In contrast to these ground-water inputs, natural recharge within the boundaries of the potential future Site is $229 \%$ higher than the simulated input contributed by Rattlesnake Hills ground water (Jacobson and Freshley 1990), and 948\% higher than the USGS (1987) estimate. 
Table 4.4. Area of Each Combination of Soil Type and Vegetation/Land Use Within the Boundaries of the Potential Future Site

\begin{tabular}{|c|c|c|c|c|c|c|c|c|c|c|c|c|c|c|c|c|c|c|}
\hline \multirow{3}{*}{\multicolumn{2}{|c|}{$\begin{array}{r}\text { Vegetation/Land Use } \\
\text { Description }\end{array}$}} & \multicolumn{15}{|c|}{ Area $\left(\mathrm{km}^{2}\right)$} & \multirow{3}{*}{$\begin{array}{c}\text { Area per } \\
\text { Veg. } \\
\text { Type } \\
\left(\mathrm{km}^{2}\right)\end{array}$} & \multirow{3}{*}{$\begin{array}{c}\text { Percent } \\
\text { of Total } \\
\text { Area }\end{array}$} \\
\hline & & \multicolumn{15}{|c|}{ Soil Types } & & \\
\hline & & $\mathbf{R i}$ & Rp & $\mathrm{He}$ & Kf & $\mathrm{Ba}$ & E1 & Ls & $\mathrm{Eb}$ & $\mathbf{K i}$ & Wa & Sc & $\mathbf{P}$ & Qu & Rv & D & & \\
\hline 1 & Shrub-steppe on slopes & & 0.11 & & & 0.04 & & & & 2.40 & & & & & & & 2.6 & 0.3 \\
\hline 2 & Shrub-steppe on plain/uplands & & 69.89 & 12.02 & 2.09 & 99.80 & 31.63 & & 6.17 & 6.02 & 0.78 & & 0.35 & 2.73 & 0.57 & & 232.0 & 30.3 \\
\hline 3 & $\begin{array}{l}\text { Recovering shrub-steppe on } \\
\text { plain/uplands }\end{array}$ & & 232.53 & 12.02 & 0.00 & 61.67 & 17.55 & & 1.01 & 2.33 & 1.55 & & 0.20 & $\begin{array}{l}3.62 \\
.\end{array}$ & & 8.95 & 341.4 & 44.6 \\
\hline 4 & Bunchgrass on slopes & & & & & & & & & & & & & & & & 0.0 & 0.0 \\
\hline 5 & Hopsage/greasewood & & & & & 0.23 & 0.02 & & & & & & & 0.45 & & & 0.7 & 0.1 \\
\hline 6 & Cheatgrass & & 15.36 & 0.27 & 0.01 & 20.99 & 29.30 & & 6.78 & 0.27 & & & 0.57 & 1.55 & 0.84 & & 75.9 & 9.9 \\
\hline 7 & Abandoned fields & & 9.08 & & & 20.53 & 4.02 & & & & & & 0.56 & & 0.38 & & 34.6 & 4.5 \\
\hline 8 & Riparian & & 0.30 & & & 0.15 & 0.16 & & 0.06 & 0.01 & & & 0.02 & & 0.14 & & 0.8 & 0.1 \\
\hline 9. & Agricultural areas & & 0.03 & & & 0.06 & & & & & & & & & & & 0.1 & 0.0 \\
\hline 10 & Sand dunes & & 12.85 & 1.33 & & 0.84 & 0.02 & & & & & & & 0.03 & 0.01 & 12.79 & 27.9 & 3.6 \\
\hline 11 & Disturbed/Facilities & & 21.46 & 0.27 & 0.04 & 9.22 & 5.72 & & 4.72 & 0.16 & 0.01 & & 0.03 & 0.24 & 0.18 & & 42.0 & 5.5 \\
\hline 12 & Water & & 0.42 & & & 0.20 & 0.27 & & 0.03 & & & & & & 0.10 & & 1.0 & 0.1 \\
\hline 13 & Basalt outcrops & & 0.04 & & & 0.19 & 0.74 & & & 4.64 & & & & & & & 5.6 & 0.7 \\
\hline & Total Area $\left(\mathrm{km}^{2}\right)$ per Soil Type $=$ & 0.0 & 362.1 & 25.9 & 2.1 & 213.9 & 89.4 & 0.0 & 18.8 & 15.8 & 2.3 & 0.0 & 1.7 & 8.6 & 2.2 & 21.7 & 764.6 & \\
\hline & Percent of Total Area $=$ & 0.0 & 47.4 & 3.4 & 0.3 & 28.0 & 11.7 & 0.0 & 2.5 & 2.1 & 0.3 & 0.0 & 0.2 & 1.1 & 0.3 & 2.8 & & \\
\hline
\end{tabular}


Table 4.5. Annual Recharge Volume for Each Combination of Soil Type and Vegetation/Land Use Within the Boundaries of the Potential Future Site. The recharge estimate for each combination is based on either measurements, modeling, or inferences from other combinations, as explained in Section 3.0.

\begin{tabular}{|c|c|c|c|c|c|c|c|c|c|c|c|c|c|c|c|c|c|c|}
\hline \multicolumn{2}{|r|}{ Vegetation/Land Use } & \multicolumn{15}{|c|}{ Annual Recharge Volume (L) } & \multirow{3}{*}{$\begin{array}{c}\text { Vol. per } \\
\text { Veg. Type } \\
\text { (L) }\end{array}$} & \multirow{3}{*}{$\begin{array}{l}\text { Percent } \\
\text { of Total } \\
\text { Volume }\end{array}$} \\
\hline & \multirow[b]{2}{*}{ Description } & \multicolumn{15}{|c|}{ Soil Types } & & \\
\hline Index & & $\mathbf{R i}$ & $\mathrm{Rp}$ & He & Kf & $\mathrm{Ba}$ & EI & Ls & Eb & $\mathbf{K i}$ & Wa & Sc & $\mathbf{P}$ & Qu & Rv & D & & \\
\hline 1 & Shrub-steppe on slopes & 0.0 & $9.7 E+05$ & 0.0 & 0.0 & $1.0 \mathrm{E}+05$ & 0.0 & 0.0 & 0.0 & $8.2 \mathrm{E}+06$ & 0.0 & 0.0 & 0.0 & 0.0 & 0.0 & 0.0 & $9.2 \mathrm{E}+06$ & 0.1 \\
\hline 2 & Shrub-steppe on plain/uplands & 0.0 & $6.0 \mathrm{E}+08$ & 3.1E+07 & $5.4 \mathrm{E}+06$ & $2.6 \mathrm{E}+08$ & $8.2 E+07$ & 0.0 & $1.6 \mathrm{E}+07$ & $2.0 \mathrm{E}+07$ & $2.7 \mathrm{E}+06$ & 0.0 & $1.2 \mathrm{E}+06$ & $9.3 E+06$ & $4.9 \mathrm{E}+06$ & 0.0 & $1.0 \mathrm{E}+09$ & 12.2 \\
\hline 3 & Recovering shrub-steppe on plain/uplands & 0.0 & $2.6 \mathrm{E}+09$ & $3.1 E+07$ & $6.5 \mathrm{E}+03$ & $1.6 \mathrm{E}+08$ & $4.6 \mathrm{E}+07$ & 0.0 & $2.6 \mathrm{E}+06$ & $7.9 \mathrm{E}+06$ & $5.3 E+06$ & 0.0 & $6.6 \mathrm{E}+05$ & $1.2 \mathrm{E}+07$ & 0.0 & $1.0 \mathrm{E}+08$ & $3.0 \mathrm{E}+09$ & 35.4 \\
\hline 4 & Bunchgrass on slopes & 0.0 & 0.0 & 0.0 & 0.0 & 0.0 & 0.0 & 0.0 & 0.0 & 0.0 & 0.0 & 0.0 & 0.0 & 0.0 & 0.0 & 0.0 & 0.0 & 0.0 \\
\hline 5 & Hopsage/greasewood & 0.0 & 0.0 & 0.0 & 0.0 & $6.0 \mathrm{E}+05$ & $3.9 E+0.4$ & 0.0 & 0.0 & 0.0 & 0.0 & 0.0 & 0.0 & $1.5 E+06$ & 0.0 & 0.0 & $2.2 E+06$ & 0.0 \\
\hline 6 & Cheatgrass & 0.0 & $3.9 E+08$ & $9.1 \mathrm{E}+05$ & $4.3 \mathrm{E}+04$ & $5.5 E+07$ & $1.4 \mathrm{E}+08$ & 0.0 & $3.3 E+07$ & $1.3 E+06$ & 0.0 & 0.0 & $2.7 E+06$ & $7.4 E+06$ & $2.1 E+07$ & 0.0 & $6.6 \mathrm{E}+08$ & 7.7 \\
\hline 7 & Abandoned fields & 0.0 & $2.3 E+08$ & 0.0 & 0.0 & $5.3 E+07$ & $2.0 E+07$ & 0.0 & 0.0 & 0.0 & 0.0 & 0.0 & $2.7 E+\infty$ & 0.0 & $9.6 \mathrm{E}+\infty$ & 0.0 & $3.2 \mathrm{E}+08$ & 3.7 \\
\hline 8 & Riparian & $0.0 \mid$ & 0.0 & 0.0 & 0.0 & 0.0 & 0.0 & 0.0 & 0.0 & 0.0 & 0.0 & 0.0 & $0.0^{\circ}$ & 0.0 & 0.0 & 0.0 & 0.0 & 0.0 \\
\hline 9 & Agricultural areas & 0.0 & 0.0 & 0.0 & 0.0 & 0.0 & 0.0 & 0.0 & 0.0 & 0.0 & 0.0 & 0.0 & 0.0 & 0.0 & 0.0 & 0.0 & 0.0 & 0.0 \\
\hline 10 & Sand dunes & 0.0 & 7.1E+08 & $7.4 \mathrm{E}+07$ & 0.0 & 4.7E+07 & $1.2 \mathrm{E}+06$ & 0.0 & 0.0 & 0.0 & 0.0 & 0.0 & 0.0 & $1.8 E+\infty$ & $4.2 \mathrm{E}+05$ & $7.1 E+08$ & $1.5 \mathrm{E}+09$ & 18.2 \\
\hline 11 & Disturbed/Facilities & 0.0 & $1.2 \mathrm{E}+09$ & $1.7 \mathrm{E}+06$ & $2.4 E+05$ & 4.1E+07 & $9.9 E+07$ & 0.0 & $8.2 E+07$ & $1.1 \mathrm{E}+06$ & $6.8 \mathrm{E}+04$ & 0.0 & $1.9 \mathrm{E}+05$ & $1.6 \mathrm{E}+06$ & $1.0 \mathrm{E}+07$ & 0.0 & $1.4 E+09$ & 16.8 \\
\hline 12 & Water & 0.0 & 0.0 & 0.0 & 0.0 & 0.0 & 0.0 & 0.0 & 0.0 & 0.0 & 0.0 & 0.0 & 0.0 & 0.0 & 0.0 & 0.0 & 0.0 & 0.0 \\
\hline 13 & Basalt outcrops & 0.0 & $3.3 E+06$ & 0.0 & 0.0 & $1.7 E+07$ & $6.4 \mathrm{E}+07$ & 0.0 & 0.0 & $4.0 E+08$ & 0.0 & 0.0 & 0.0 & 0.0 & 0.0 & 0.0 & $4.9 E+08$ & 5.7 \\
\hline & Annual Volume (L) per Soil Type $=$ & 0.0 & $5.8 \mathrm{E}+09$ & $1.4 \mathrm{E}+08$ & $5.7 \mathrm{E}+06$ & $6.3 E+08$ & $4.6 \mathrm{E}+08$ & 0.0 & $1.3 \mathrm{E}+08$ & $4.4 E+08$ & $8.0 E+\infty$ & 0.0 & $7.5 E+06$ & $3.4 \mathrm{E}+07$ & $4.6 \mathrm{E}+07$ & $8.1 E+08$ & $8.5 E+09$ & \\
\hline & Percent of Total Volume $=$ & 0.0 & 68.0 & 1.6 & 0.1 & 7.5 & 5.4 & 0.0 & 1.6 & 5.2 & 0.1 & 0.0 & 0.1 & 0.4 & 0.5 & 9.6 & & \\
\hline
\end{tabular}


Jacobson and Freshley (1990) reported that the volume of 200 Area facility discharges was $7.63 \times 1010 \mathrm{~L}$ in 1979 . In contrast to this ground-water input, estimated natural recharge within the boundaries of the potential future Site is about 52\%. In 1992, the facility discharges and estimated recharge volumes were equivalent.

\subsection{Unresolved Issues}

The map of estimated recharge rates (Figure 4.1) was prepared using the available data. The map was not constructed with pre-defined accuracy or precision objectives, nor were estimates of the uncertainty in the input parameters used to calculate the uncertainty in the estimated recharge rates. If natural recharge rates are shown to be important to the successful modeling of ground-water movement by the Ground-Water Surveillance Project, such calculations could be performed. In addition to the concerns about accuracy, precision, and uncertainty, five issues remain unresolved: estimation methods, appropriate soil and vegetation data, spatial and temporal averaging, the impact of structures, and basalt outcrops and shallow soils.

\subsubsection{Estimation Methods}

Issues related to estimation methods include accuracy of, and differences between, techniques, model credibility, and timing and location of measurements. Each technique has advantages and disadvantages in addition to its individual accuracy and precision limits. These are discussed in a series of papers (e.g., Allison et al. 1994) in the January-February 1994 issue of the Soïl Science Society of America Journal.

The credibility of model results is determined by comparisons with field data. Simulation model results were applied to $57 \%$ of the area of the future Site because site-specific measurements (e.g., drainage, water contents, tracers) were lacking. If recharge maps such as Figure 4.1 continue to be used, and improved, then estimated recharge rates for soil-vegetation combinations that rely on model results can gain credibility if the model results are compared to field data.

Estimated recharge rates are affected by the measurement periods of each technique. The chloride data span 13000 years, the Cl-36 data and computer modeling span 35 years, and the lysimeter and water content measurements span less than 10 years (in some cases, only 3 years). Figure 4.1 was produced with data from all but the chloride method, so the map can be considered reflective of rates during the last 3 to 35 years.

Location of measurement in the soil profile is an issue when the estimated recharge rates are being used to drive a ground-water model. All the recharge rates are measured near the soil surface, not at the water table. If these recharge rates continued indefinitely without change, then eventually they would reach the water table and using them would be appropriate to drive a ground-water model. Unfortunately, the ground-water model must have the rates that are reaching the water table in a particular year, for example, 1979. None of the measurement techniques discussed can yield these rates, so they must be inferred based on estimates of historical rates. These rates can be assumed to be the rates for each soil under the shrub-steppe cover (Table 4.1); an improvement would be to substitute chloride estimates where they exist. One disadvantage of this method is that in those areas with disturbance and high recharge, the impact of the disturbance may already have reached the water table in the year designated (e.g., 1979). Whether it did depends on the recharge rate, the thickness of the unsaturated zone, and the soil water content. 


\subsubsection{Appropriate Soil and Vegetation/Land Use Data}

The available data on soil types at the Hanford Site are severely limited. The sources are old, poorly correlated to the soil surveys of the Soil Conservation Service, and most importantly, the soil types were not defined using criteria for predicting recharge (criteria such as identifying major layers, soil hydraulic properties of each layer, depths, gravel content). For each soil type, the range of parameters, i.e., the probability density function, is needed to gauge the uncertainty of any estimates.

The plant survey (Downs et al. 1993) provided some information, but again, the objective was not to provide modeling parameters. Plants respond differently when grown on different soil types, yet plant data specific to soil types are unavailable. Land use/vegetation categories did not indicate vegetation cover on the sand dunes, basalt outcrop areas, or disturbed areas, yet some vegetation is known to exist in these areas.

\subsubsection{Spatial and Temporal Averaging}

Recharge appears to be affected by processes at the meter scale, yet the soil and vegetation maps are at scales of $10 \mathrm{~s}$ to $100 \mathrm{~s}$ meters. Thus, the coarseness of the spatial distribution of the soil and vegetation data may degrade the accuracy of the recharge estimations. The accuracy of the recharge estimates could be improved in highly vulnerable areas by characterizing at smaller scales, but this would be expensive for the entire Site. Because the issue of scales in environmental processes is a current research topic (American Geophysical Union 1991), there is hope that new methods for analyzing processes over many scales may become available.

The simulation results in Appendix B showed clearly that recharge rates can vary significantly from year to year and decade to decade. This result was most evident for the Ephrata sandy loam under a bunchgrass cover, where significant recharge occurred only three times in 35 years. Consider the implication for monitoring projects: a 5-year experiment to measure recharge in such a system might totally miss the few recharge events that essentially determine the long-term recharge rate. An appropriate analogy might be meteorology, where climate is determined by weather statistics (i.e., averages). These statistics are calculated for periods of 30 years or more. A long-term recharge rate might therefore be more accurately called a recharge climate. Furthermore, recharge rates might be better predicted by climate periods of 30 years or more.

\subsubsection{Impact of Structures}

Very little is known about the impact of human-made structures on recharge. These structures include buildings, parking lots, roads, firebreaks, power lines, and disposal areas. Data are available from lysimeters that mimic gravel-covered tank farms; these data (see Section 2.2.1) form the basis for estimating recharge beneath basalt outcrops. Structures such as tank farms can be found in the areas classified as disturbed (see Figure 2.4). They were not factored into the recharge estimates for these areas, however, because Figure 2.4 did not allow for differentiation between such things as a tank farm and an adjacent lot covered by shrub-steppe vegetation. In lieu of including detailed spatial information in the disturbed areas, the average recharge rates were estimated using simulation results for bare soil. This lack of information on disturbed areas highlights an important issue: how to estimate the average recharge rate of disturbed areas when there is significant variability in the recharge rate within the area.

Some data are also available for disturbances where vegetation has been removed (e.g., firebreaks, power lines). However, these disturbances are not represented in the vegetation/land use map 
and therefore were not included in the recharge estimates. The importance of such disturbances can be estimated. Assuming the total length of these features is $390 \mathrm{~km}$ (the estimated length of existing roads), and the width is $11.6 \mathrm{~m}$, the total area is $4.5 \mathrm{~km}^{2}$. If half of that occurs on Rupert sand, and the vegetation is changed from shrub-steppe (the pre-disturbed state) to cheatgrass (the disturbed state), the recharge volume increases by $7.56 \times 10^{7} \mathrm{~L}$, which represents about $1 \%$ of the total recharge volume within the future Site boundaries.

Roads are similar to firebreaks and power lines in that the road shoulders are kept free of vegetation. The similarity stops there, however. The road surface reduces recharge to zero by causing precipitation water to flow off of the surface. The water reaches the shoulders and infiltrates over a small area. Plants cannot access this water, and gravel usually limits evaporation, thus the potential for recharge is very high. An estimate of the recharge potential of roads can be determined. If the road shoulder width on each side is $11.6 \mathrm{~m}$, the total area is $9.0 \mathrm{~km}^{2}$ (total road length of $390 \mathrm{~km}$ ). Assuming the recharge rate is $86.7 \mathrm{~mm} / \mathrm{yr}$ (the rate determined for gravel-covered lysimeters, see Section 2.2.1), the contribution of roads to the recharge volume is $7.80 \times 10^{8} \mathrm{~L}$. This amount represents $9 \%$ of the total recharge volume within the boundaries of the potential future Site. While this is a small fraction of the total amount, the contribution to localized recharge could be great.

The effect of roads is further exacerbated whenever there is snow. Snow plows move the snow off the road and into piles on the shoulder, which contributes to the recharge potential because it focuses large amounts of water in a small area. A similar situation occurs in parking lots, where snow is plowed into huge piles at the edges where it is free to melt and infiltrate the surrounding soil. The melt water is not routed into storm sewers as it is in Richland.

It is difficult not only to quantify the effect of structures such as roads on recharge, but to include the effect in an average rate for highly disturbed areas. A good example is the large disturbed areas in the 200 Areas, which contain all of the features just discussed. The range of recharge rates in the 200 Areas is probably very large and determining an "average" recharge rate will be a challenge.

\subsubsection{Basalt Outcrops and Shallow Soils}

Basalt outcrops occur almost entirely at the crests of Rattlesnake Mountain and Gable Mountain and Gable Butte. When considering recharge within the area bounded by Highway 240 and the Columbia River, Rattlesnake Mountain is not a factor and only Gable Mountain and Gable Butte need be considered. While Table 4.4 shows that $83 \%$ of the basalt outcrop area was mapped as Kiona silt loam, a shallow soil, for this report, the areas with basalt outcrop were treated as being devoid of soil and vegetation. A survey could be conducted to better delineate the fraction of this area covered with some soil and vegetation. Estimates of recharge rates under even a thin soil cover with vegetation are much less than estimates of recharge rates under basalt outcrop.

Shallow soils were not addressed in this report, but their presence could have an impact on recharge rates if the underlying basalt bedrock is fractured such that flow paths exist. The scenario is that soil sitting on gravel and fractured basalt might behave like a capillary barrier, which enhances evapotranspiration and decreases drainage. The thickness of shallow soil may be insufficient to store all precipitation, and thus drainage can occur before the water evaporates. Furthermore, the basalt bedrock may limit rooting depths, thus limiting transpiration and increasing the potential for recharge. The soils in question include the Kiona and Lickskillet silt loams, some areas of the Ritzville silt loam, and the Ephrata stony loam. If the basalt bedrock beneath these soils is fractured 
and connected with the ground-water system, then further study of the recharge rates in these soils is warranted. If the basalt bedrock is not fractured and connected to the ground water, then recharge in these soils may be considered unimportant to the project. 


\subsection{Strategy for Improving the Recharge Map}

The objective of the Water Budget at Hanford subtask of the Ground-Water Surveillance Project is to produce a defensible map of estimated recharge rates across the Hanford Site. Such a map was produced using estimates with different degrees of defensibility. Issues that reduce the defensibility of the estimates were discussed in Section 4.0.

For the Ground-Water Surveillance Project, the importance of natural recharge is directly related to what impact it has on ground-water flow paths and travel times. In this report, the volume of estimated recharge was shown to be comparable to both artificial recharge in the 200 Areas and water flow from the higher elevations to the west. Figure 4.1 showed that the distribution of estimated recharge was highly skewed to the disturbed sandy soils (e.g., in the 200 Areas, where most contaminants originate). The results suggest that the recharge estimates should be improved until there is greater confidence in the estimates associated with specific soil types and vegetative covers and more is known about the influence of disturbed areas. Six recommendations for improving the recharge rates are presented below.

1. Improved soil survey. Much of this report relies on the soil map (Figure 2.3) that was produced nearly 30 years ago (Hajek 1966), mostly with data from 80 years ago (Kocher and Strahorn 1919) when the need to estimate recharge rates was not considered by the soil surveyors. The defensibility of the recharge map could be vastly improved if the Site were surveyed by professional soil scientists from the Soil Conservation Service who could map the Site with project-specific needs in mind. Such a survey would not only improve recharge estimates, but would support the needs of the operable units, enable far better land use decisions as the Site transitions from its nuclear production mission to a cleanup mission, and would correspond to contemporary surveys in the surrounding counties.

2. Improved vegetation survey. The vegetation/land use map (Figure 2.4 ) was originally produced for reasons other than the need to estimate recharge. Ground surveys were conducted, but the results have not been processed or published. When they are made available, the survey results can be used to improve the cover type descriptions, especially for the model simulations.

3. Improved soil characterization. Two soil types that are prevalent in the 200 Areas are the Ephrata sandy loam and Burbank loamy sand. These soils have not been well-characterized. Model simulations of these soils were conducted using surrogate hydraulic properties taken from well samples.

Table B.1 of Appendix B indicates that the hydraulic conductivity values that were used were $10 \mathrm{x}$ to 50x less than values reported by the USDA (1971) for similar soils. Because they dominate the 200 Areas, the Ephrata sandy loam and Burbank loamy sand should be specifically studied and in situ properties should be measured.

4. Improved estimate of plant species change. The recovering shrub-steppe cover, the result of a 1984 fire, had a large impact on recharge rates. This cover type was approximated as a bunchgrass with $50 \%$ cover. Ground surveys should verify the appropriateness of this approximation; if inappropriate, the computer model simulations should be repeated with the new information. Because it had such an impact on estimated rates, fire should be considered in studies of future rates. Such studies should address species turnover, i.e., whether shrub-steppe will be replaced with an invader species such as cheatgrass, a change that would lead to increased recharge.

5. Measurements of recharge in vegetated Rupert sand. Sixty-eight percent of the recharge volume of the potential future Site occurred under the Rupert sand, half of that under the shrub- and 
recovering shrub-steppe covers. Recharge estimates for these covers were based on simulations. Given the large volume of predicted recharge water, some attempt should be made to obtain corroborative field data.

6. Improved estimates of recharge in disturbed areas. Disturbed areas contribute the largest amount of site-specific recharge, yet very little is known about this recharge source. Calculations of the contribution just from paved roads show that the recharge volume could be $9 \%$ of the total recharge volume within the boundaries of the potential future Site. Considering unpaved roads, power lines, firebreaks, parking lots, and disposal areas, the volume of recharge contributed by these disturbances could far exceed the total from the estimated natural rates for the whole Site. These rates are highly localized and were not captured in the recharge map (Figure 4.1), in which disturbed areas were treated as unvegetated soil. Refinement and additions to the disturbed areas category in Figure 2.4 could be made by using existing aerial photographs and satellite imagery. Then improved methods should be found to estimate the rate and distribution of recharge in these disturbed areas so that its impact on ground-water flow and contaminant transport can be determined. 


\subsection{References}

Allison, G. B., G. W. Gee, and S. W. Tyler. 1994. "Vadose-Zone Techniques for Estimating Groundwater Recharge in Arid and Semiarid Regions." Soil Sci. Soc. Am. J. 58:6-14.

American Geophysical Union (AGU). 1989. "Contributions in Hydrology." U.S. National Report 1987-1990, Twentieth General Assembly International Union of Geodesy and Geophysics, Vienna, Austria, August 11-24, 1991.

Bauer, H. H., and J. J. Vaccaro. 1990. Estimates of Ground-Water Recharge to the Columbia Plateau Regional Aquifer System, Washington, Oregon, and Idaho, for Predevelopment and Current Land-Use Conditions. WRIR 88-4108, U.S. Geological Survey.

Cushing, C. E. (ed.). 1994. Hanford Site National Environmental Policy Act (NEPA) Characterization. PNL-6415, Rev. 6, Pacific Northwest Laboratory, Richland, Washington.

U.S. Department of Energy (DOE). 1987. Disposal of Hanford Defense High-Level, Transuranic and Tank Wastes. DOE/EIS-0113, U.S. Department of Energy, Richland, Washington.

Downs, J. L., W. H. Rickard, C. A. Brandt, L. L. Cadwell, C. E. Cushing, D. R. Geist, R. M. Mazaika, D. A. Neitzel, L. E. Rogers, M. R. Sackschewsky, and J. J. Nugent. 1993. Habitat Types on the Hanford Site: Wildlife and Plant Species of Concern. PNL-8942, Pacific Northwest Laboratory, Richland, Washington.

Dudziak, S. 1988. Simulating Unsaturated Flow Through a Gravel-Covered, Multilayered Lysimeter. Master's thesis, University of Idaho, December 1988.

Fayer, M. J., G. W. Gee, and T. L. Jones. 1986. UNSAT-H Version 1.0: Unsaturated Flow Code Documentation and Applications-for the Hanford Site. PNL-5899, Pacific Northwest Laboratory, Richland, Washington.

Fayer, M. J., and T. L. Jones. 1990. UNSAT-H Version 2.0: Unsaturated Soil Water and Heat Flow Model. PNL-6779, Pacific Northwest Laboratory, Richland, Washington.

Fayer, M. J., and G. W. Gee. 1992. "Predicted Drainage at a Semiarid Site: Sensitivity to Hydraulic Property Description and Vapor Flow." In Proceedings of the International Workshop on Indirect Methods for Estimating the Hydraulic Properties of Unsaturated Soils, M. Th. van Genucthen, F. J. Leij, and L. J. Lund, eds., Riverside, California, October 11-13, 1989, University of California, Riverside.

Gee, G. W., and R. R. Kirkham. 1984. Arid Site Water Balance: Evapotranspiration Modeling and Measurements. PNL-5177, Pacific Northwest Laboratory, Richland, Washington.

Gee, G. W., P. A. Beedlow, and R. L. Skaggs. 1988. "Water Balance." In Shrub-Steppe Balance and Change in a Semi-Arid Terrestrial Ecosystem. W. H Rickard-et al., ed., Developments in Agricultural and Managed-Forest Ecology 20, Elesevier Science Publishers, New York.

Gee, G. W., and D. Hillel. 1988. "Groundwater Recharge in Arid Regions: Review and Critique of Estimation Methods." Hydrologic Processes 2:255-266. 
Gee, G. W., M. J. Fayer, M. L. Rockhold, and M. D. Campbell. 1992. "Variations in Recharge at the Hanford Site." Northwest Sci. 66:237-250.

Gee, G. W., D. G. Felmy, J. C. Ritter, M. D. Campbell, J. L. Downs, M. J. Fayer, R. R. Kirkham, and S. O. Link. 1993. Field Lysimeter Test Facility Status Report IV: FY 1993. PNL-8911, Pacific Northwest Laboratory, Richland, Washington.

Gee, G. W., P. J. Wierenga, B. J. Andraski, M. H. Young, M. J. Fayer, and M. L. Rockhold. 1994. "Variations in Water Balance and Recharge Potential at Three Western Desert Sites." Soil Sci. Soc. Am. J. 58:63-72.

Gupta, S. K., C. R. Cole, C. T. Kincaid, and A. M. Monti. 1987. Coupled Fluid, Energy, and Solute Transport (CFEST) Model: Formulation and Users Manual. BMI/ONWI-660. Prepared for the U.S. Department of Energy by Battelle Project Management Division, Office of Nuclear Waste Isolation, Columbus, Ohio, and Pacific Northwest Laboratory, Richland, Washington.

Hajek, B. F. 1966. Soil Survey Hanford Project in Benton County Washington. BNWL-243, Pacific Northwest Laboratory, Richland, Washington.

Hinds, 1975. "Energy and Carbon Balances in Cheatgrass: An Essay in Autecology." Ecological Monographs, 45:367-388.

Hoitink, D. J. and K. W. Burk. 1994. Climatological Data Summary 1993 with Historical Data. PNL-9809, Pacific Northwest Laboratory, Richland, Washington.

Jacobson, E. A., and M. D. Freshley. 1990. An Initial Inverse Calibration of the Ground-water Flow Model for the Hanford Unconfined Aquifer. PNL-7144, Pacific Northwest Laboratory, Richland, Washington.

Jones, T. L. 1989: Simulating the Water Balance of an Arid Site. PNL-SA-17633, Pacific Northwest Laboratory, Richland, Washington.

Kocher, A. E., and A. T. Strahorn. 1919. Soil Survey of Benton County, Washington. U.S. Government Printing Office.

Link, S. O., G. W. Gee, M. E.Thiede, and P. A. Beedlow. 1990. "Response of a Shrub-Steppe Ecosystem to Fire: Soil Water and Vegetational Change." Arid Soil Research and Rehabilitation, $4: 163-172$.

Murphy, E. M., J. E. Szecsody, and S. J. Phillips. 1991. A Study Plan for Determining Recharge Rates at the Hanford Site Using Environmental Tracers. PNL-7626, Pacific Northwest Laboratory, Richland, Washington.

Pearce, D. W. R. E. Brown, and T. P. O'Farrell. 1969. The Arid Lands Ecology Reserve at Pacific Northwest Laboratory, Richland, Washington. BNWL-SA-2574, Pacific Northwest Laboratory, Richland, Washington.

Prych, E. A. 1994 in press. Estimating Deep-Percolation Rates at Selected Locations on the USDOE Hanford Site, WA, Using Two Chloride-Tracer Methods. Open File Report 94-514. U.S. Geological Survey, Tacoma, Washington. 
Rasmussen, J. J. 1971. Soil Survey of Benton County Area, Washington. U.S. Government Printing Office.

Rickard, W. H., and B. E. Vaughan. 1988. "Plant Community Characteristics and Responses." In Shrub-Steppe Balance and Change in a Semi-Arid Terrestrial Ecosystem. W. H Rickard et al., ed., Developments in Agricultural and Managed-Forest Ecology 20, Elsevier Science Publishers, New York.

Sackschewsky, M. R., D. S. Landeen, G. I. Baird, W. H. Rickard, and J. L. Downs. 1992. Vascular Plants of the Hanford Site. WHC-EP-0554, Westinghouse Hanford Company, Richland, Washington.

Stone, W. A., J. M. Thorp, O. P. Gifford, and D. J. Hoitink. 1983. Climatological Summary for the Hanford Area. PNL-4622, Pacific Northwest Laboratory, Richland, Washington.

Thorp, J. M., and W. T. Hinds. 1977. Microclimates of the Arid Lands Ecology Reserve. BNWL-SA-6231, Pacific Northwest Laboratory, Richland, Washington.

U.S. Department of Agriculture (USDA). 1971. Soil Survey, Benton County Area, Washington. U.S. Government Printing Office, Washington, D.C. Issued July 1971.

U.S. Geological Survey (USGS). 1987. Subsurface Transport of Radionuclides in Shallow Deposits of the Hanford Nuclear Reservation, Washington - Review of Selected Previous Work and Suggestions for Further Study. Open-File Report 87-222.

Woodruff, R. K., R. W. Hanf, and R. E. Lundgren. 1993. Hanford Site Environmental Report for Calendar Year 1992. PNL-8682, Pacific Northwest Laboratory, Richland, Washington.

Wurstner, S. K., and J. L. Devary. 1993. Hanford Site Ground-Water Model: Geographic Information System Linkages and Model Enhancements, FY 1993. PNL-8991, Pacific Northwest Laboratory, Richland, Washington. 


\section{Appendix A}

\section{Estimated Recharge at the 300 Area Grass Site}

This Appendix summarizes a paper that was presented at the 1991 Annual Meeting of the Soil Science Society of America in Denver, Colorado. The paper was expanded for this report. 


\title{
Multiyear Observations of Water Content to Characterize Low Recharge
}

\author{
by M. J. Fayer, M. L. Rockhold, R. R. Kirkham, and G. W. Gee
}

\begin{abstract}
Recharge rates as low as $0.5 \mathrm{~mm} / \mathrm{yr}$ are of concern in predicting the transport of contaminants located within the vadose zone at the Hanford Site, which is located in arid south-central Washington. At a grass-covered site selected for a multiyear study of recharge, 25 access tubes for a neutron probe were installed to the $3.5-\mathrm{m}$ depth in a five-by-five grid with a spacing of $6 \mathrm{~m}$. Monitoring of soil water contents with the probe began in January 1983. The 8-year record of water contents at this site shows a pattern of higher water contents during the winter and lower water contents during the summer. Deep storage changes and unit gradient calculations provided estimates of recharge ranging from 3.0 to $>140.0 \mathrm{~mm} / \mathrm{yr}$. These estimates indicate that recharge is more readily related to precipitation received between November and January than to annual amounts. For the 8-year period of observation, the average estimated recharge rate was $25.4 \mathrm{~mm} / \mathrm{yr}$. Spatial variations revealed that recharge varies over lengths less than $6 \mathrm{~m}$. Year-to-year variations revealed that short-term measure- . ments inadequately characterized the long-term behavior of recharge at this site.
\end{abstract}




\section{Introduction}

Natural ground-water recharge originates when soil water moves sufficiently deep into the soil so that evaporation and plant transpiration cannot remove it to the atmosphere, and it is free to move downward to the water table. Recharge water can transport contaminants that have been disposed of, or stored, in the vadose (i.e., unsaturated) zone. The Hanford Site, located in south-central Washington State, is predominantly covered with sandy soil (Figure 2.3) and contains many areas in which contaminants are present in the vadose zone.

The objective of this study was to quantify year-to-year natural recharge rates beneath a grass covered sand typical of the Hanford Site. These recharge rates can then be-used to estimate potential waste migration and fate.

\section{Methods}

A research site was established in January 1983 on relatively flat terrain in the 300 Area to study recharge. Although shrubs were not present at the time (Gee and Kirkham 1984), shrubs could have been present prior to 1982 and somehow removed. The most likely methods of shrub removal are fire and farming. The absence of burnt sage plants and evidence of farming indicated that shrubs were not present for many years prior to 1982. During the experiment, the area burned in August 1984.

Sieving and hydrometer analyses indicated that the soil texture graded from a sandy loam at the surface to sand at deeper depths. Data reported by Gee et al. (1989) show that the texture was sandy loam from 0 to $15 \mathrm{~cm}$, loamy sand from 15 to $40 \mathrm{~cm}$, and sand from $40 \mathrm{~cm}$ to $95 \mathrm{~cm}$. They reported that the saturated hydraulic conductivity of the sand ranged from 1.67 to $2.68 \times 10^{-5} \mathrm{~m} / \mathrm{s}$. Gee and Kirkham (1984) reported that the sand continued to the $3.5-\mathrm{m}$ depth, at which they encountered a rock/gravel layer.

Twenty-five neutron probe access tubes were installed in a $5 \times 5$ grid with a 6-m spacing between tubes. The installation method consisted of driving a split-tube sampler $50 \mathrm{~cm}$, then driving in the surrounding casing to the same depth, extracting the split-tube sampler, and removing soil material from the sampler. These steps were repeated until the casing (i.e., the access tube) was installed to a depth of approximately $3.5 \mathrm{~m}$. This method was chosen to ensure a tight seal between the soil and the outside of the tubes (Gee and Kirkham 1984). Starting in January 1983, soil water contents were monitored down to the $3.5-\mathrm{m}$ depth. Data from six of the tubes are not reported here because the surfaces were disturbed for specific treatments (e.g., herbicides, rototilling), thus precluding their use for estimating recharge rates in a natural setting.

Sandberg's bluegrass and cheatgrass are the dominant plants, having canopy coverages of 30 and 20 percent, respectively; the inter-plant spaces are occupied by lichens and mosses (Link et al. 1990). Soil cores provided evidence that plant roots were predominantly in the upper $20 \mathrm{~cm}$. Gee and Kirkham (1984) reported that $99 \%$ of the roots were above $60 \mathrm{~cm}$. Link et al. (1990) and Reece (1991) reported similar results, finding no roots deeper than $60 \mathrm{~cm}$.

A variation of the zero-flux plane method (Allison et al. 1994) was used to estimate recharge. Measurements of hydraulic head gradients were needed to identify the zero-flux plane throughout the experiment. Such measurements did not exist at this site. In lieu of these measurements, a depth of $120 \mathrm{~cm}$ was identified as that depth below which water flow was strictly downward. Some cvidence 
to support this assumption exists. Plant roots were not observed below $60 \mathrm{~cm}$. Tension measurements in 1988 and 1989 indicated unit-gradient conditions below the 120-cm depth (Rockhold et al. 1990). As the results will show, the soil was fairly dry in those years; thus, similar conditions likely existed during the wetter years.

The recharge rate was estimated using the observed annual decrease in water stored between the 120- to 315-cm depths:

$$
r=q_{120}-d S / d t
$$

where $\mathbf{r}=$ estimated recharge (the flux at the $315-\mathrm{cm}$ depth)

$\mathrm{q}_{120}=$ flux at $120-\mathrm{cm}$ depth (assumed to be zero during part of year)

dS = change in soil water storage between depths of 120 and $315 \mathrm{~cm}$

$\mathrm{dt}=$ duration (treated as $1 \mathrm{yr}$ ).

For each year, the change in storage is calculated from the maximum storage value to the subsequent minimum value. During this time, $q_{120}$ is treated as zero. Figure A.1 shows how the calculation was performed for the average $(n=19)$ access tube in 1984 . The decrease in storage was $44.7 \mathrm{~mm}$ and $\mathrm{q}_{120}$ was zero, so that the estimated recharge rate was $44.7 \mathrm{~mm} / \mathrm{yr}$. Use of Equation A.1 will lead to underestimates of recharge for two reasons. First, $\mathrm{q}_{120}$ is considered to be zero during the early part of the calculation interval (when flow is still occurring). Second, $r$ is assumed to be zero during the period when $S$ is increasing. Unfortunately, no method exists to determine either $q_{120}$ or $r$ directly during these two periods.

\section{Results and Discussion}

Figure A.2 shows the variation in water content at three depths during the eight-year period. In each year, the peak water content at each depth occurred at a later time, indicating that significant quantities of water were moving downward. In some years, the amplitudes in water content were much smaller at $120 \mathrm{~cm}$ and nearly nonexistent at the lower depths, indicating that very little water was moving downward. Year-to-year variability depends on the weather. Figure A.3 shows the annual precipitation relative to the mean during the period 1951-1980 (Stone et al. 1983; Hoitink and Burk 1994). Some relationship between annual precipitation amounts and water content variations exists, but the correspondence doesn't appear to be strong. This result was expected because recharge processes are sensitive to much smaller time intervals of days, weeks, and months.

Figure A.4 shows monthly deviations of both precipitation and air temperature. It will be shown later that a good indicator of recharge is the precipitation received between November and January $\left(r^{2}=0.916\right)$. During the first four years, when the water contents were varying widely each year, much of the precipitation was received between November and January and temperatures were generally cooler than the mean. During the second four years, the November to January precipitation levels were less, and the monthly air temperatures were much higher than the mean. This observation may explain, in part, why the high precipitation in early 1989 did not produce a significant response in the water contents deep within the profile.

The storage of water was calculated for two zones of the profile: 0 to $120 \mathrm{~cm}$ and 120 to $315 \mathrm{~cm}$. Figure A.5 shows that storage between 0 and $120 \mathrm{~cm}$ varied seasonally over a range from 


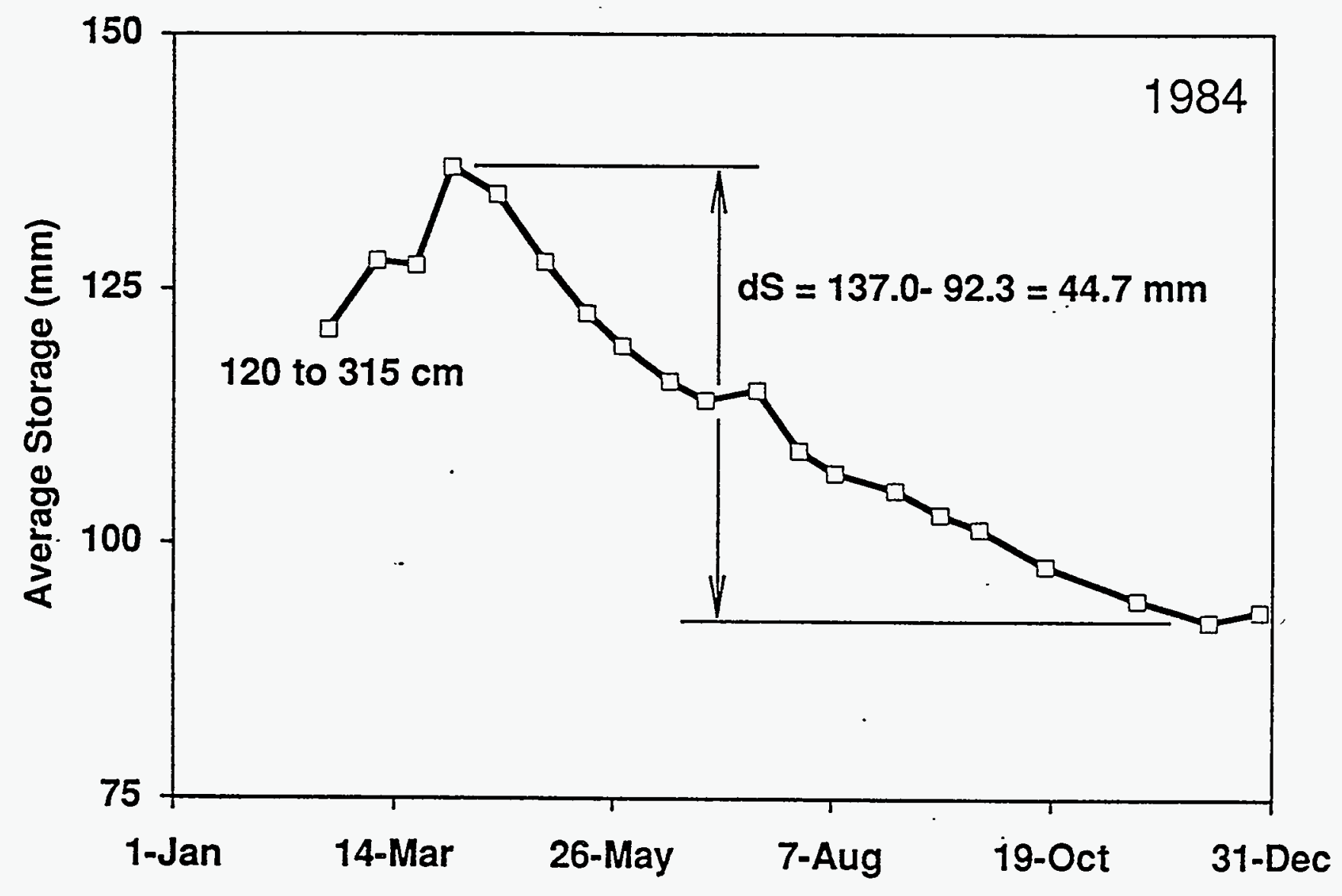

Figure A.1. Recharge Estimation Method

A. 4 


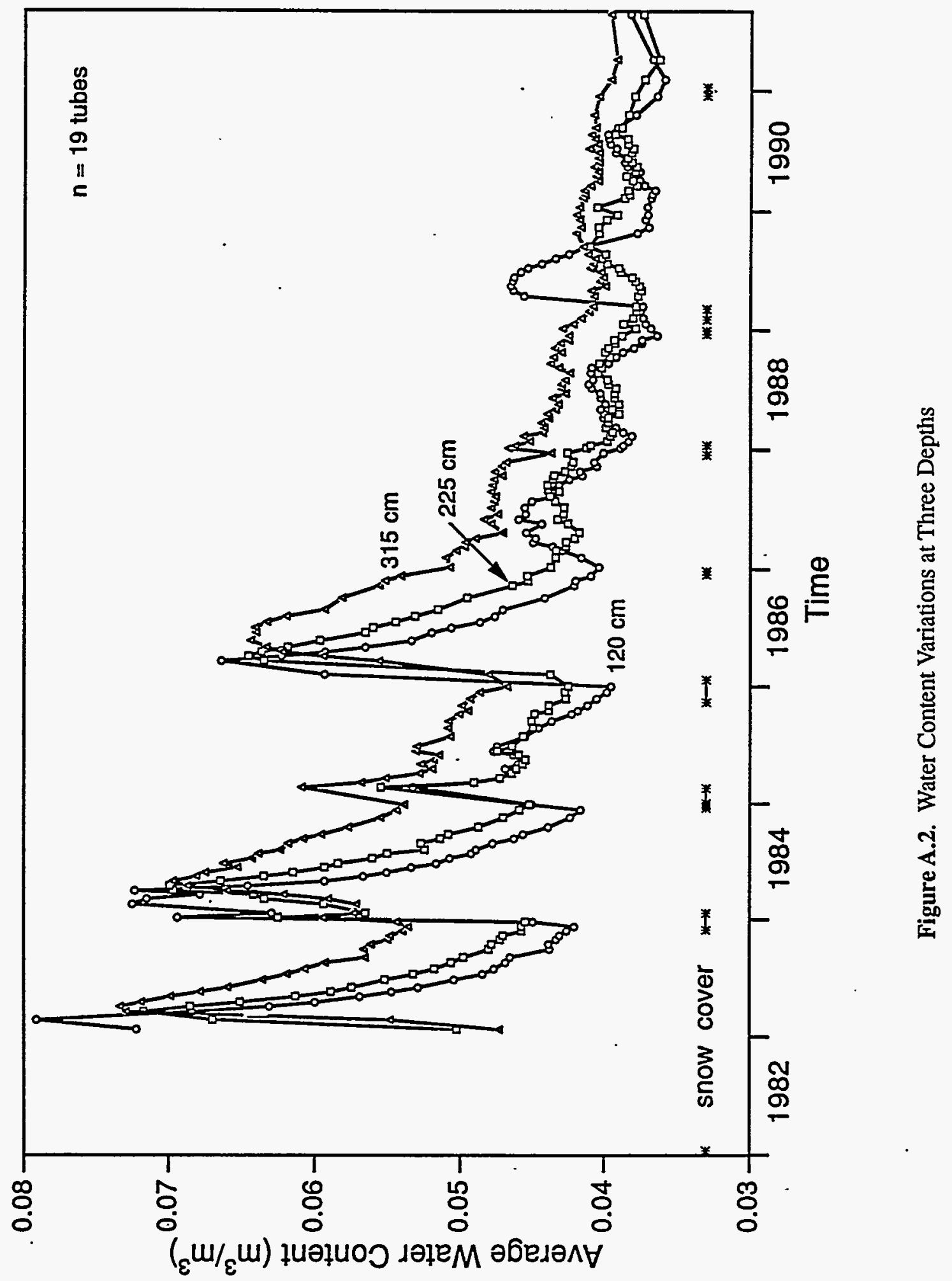

A. 5 


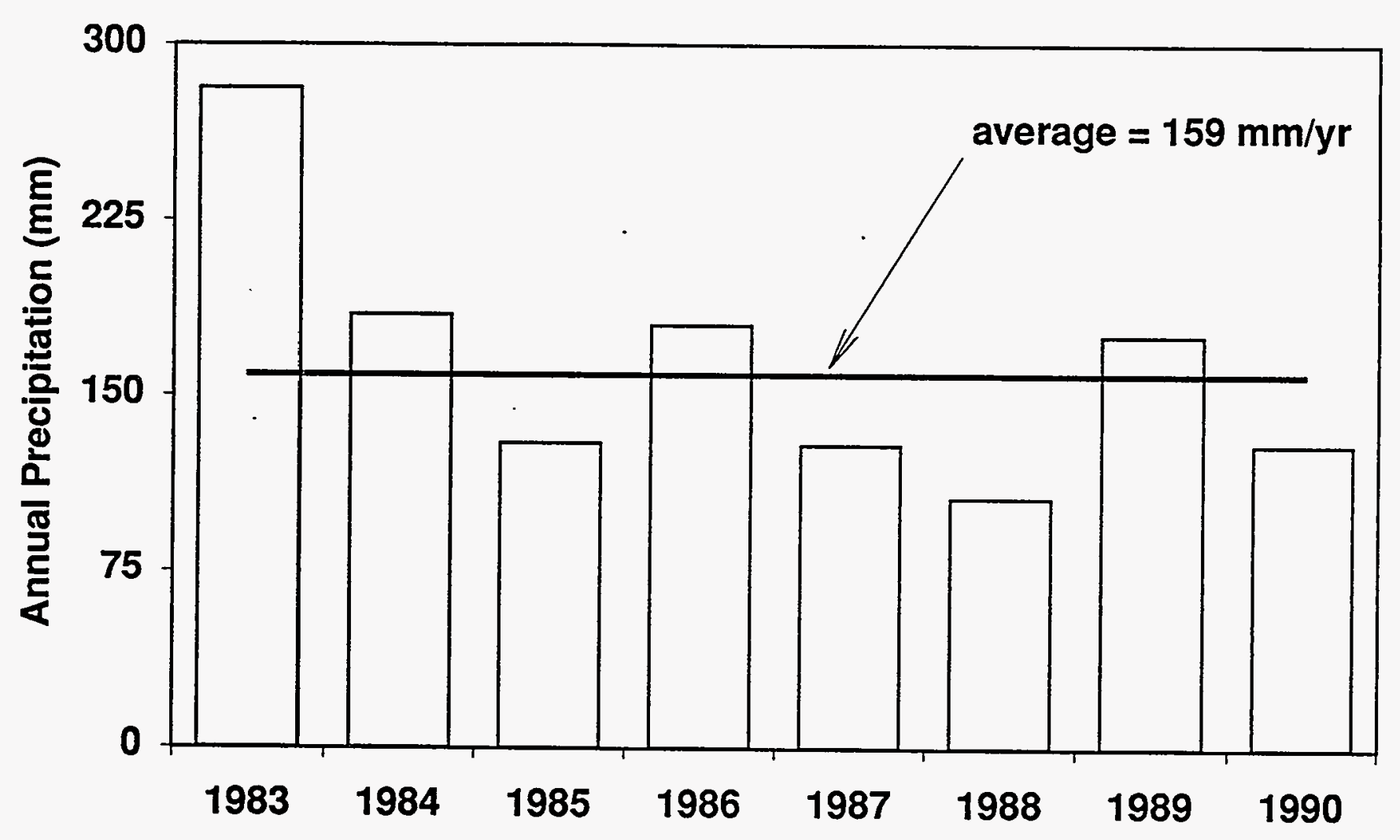

Figure A.3. Annual Precipitation Variations Relative to the 1951-1980 Average at the Hanford Meteorological Station 

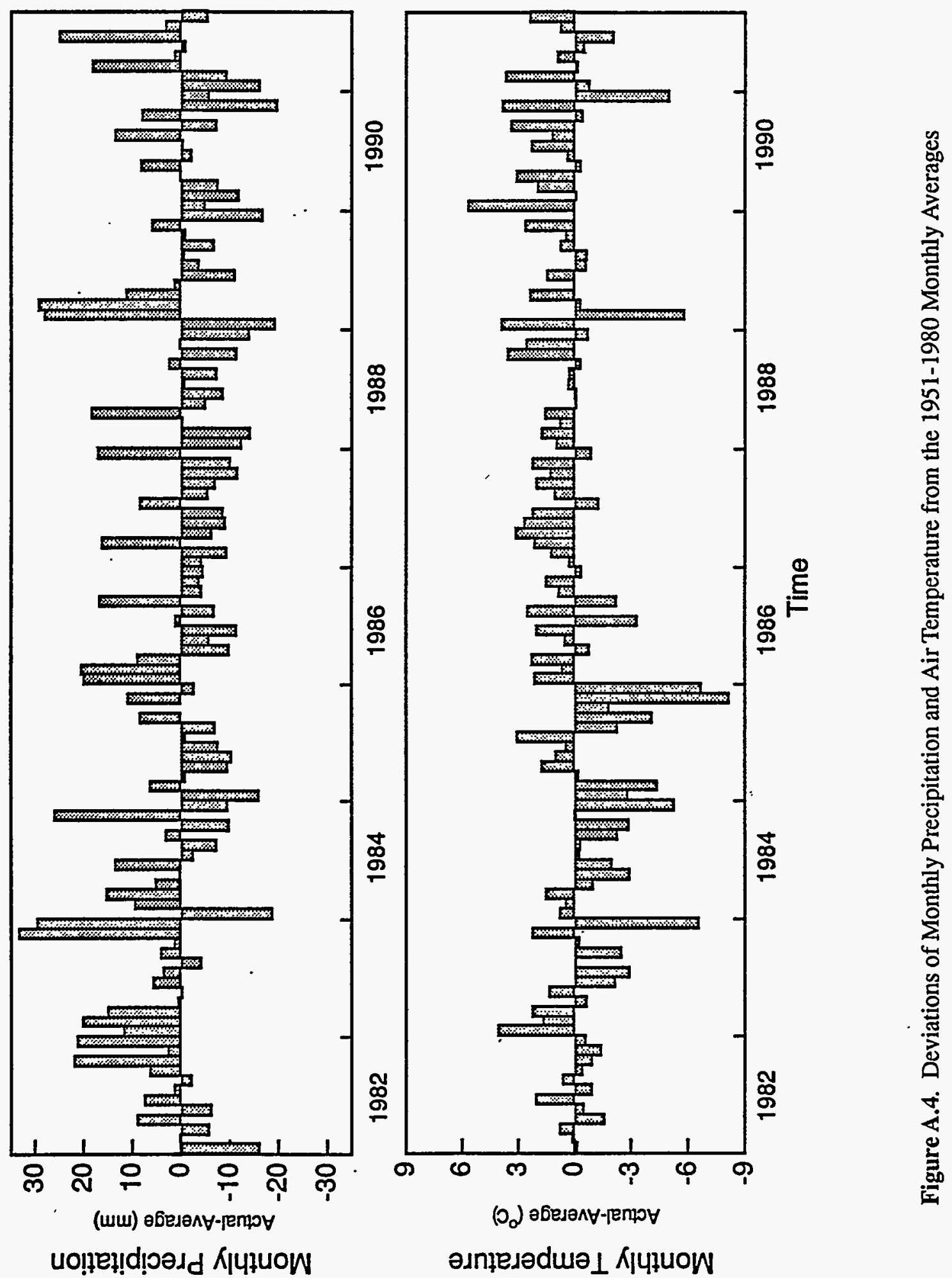

(O) абеләл

әлnłe 


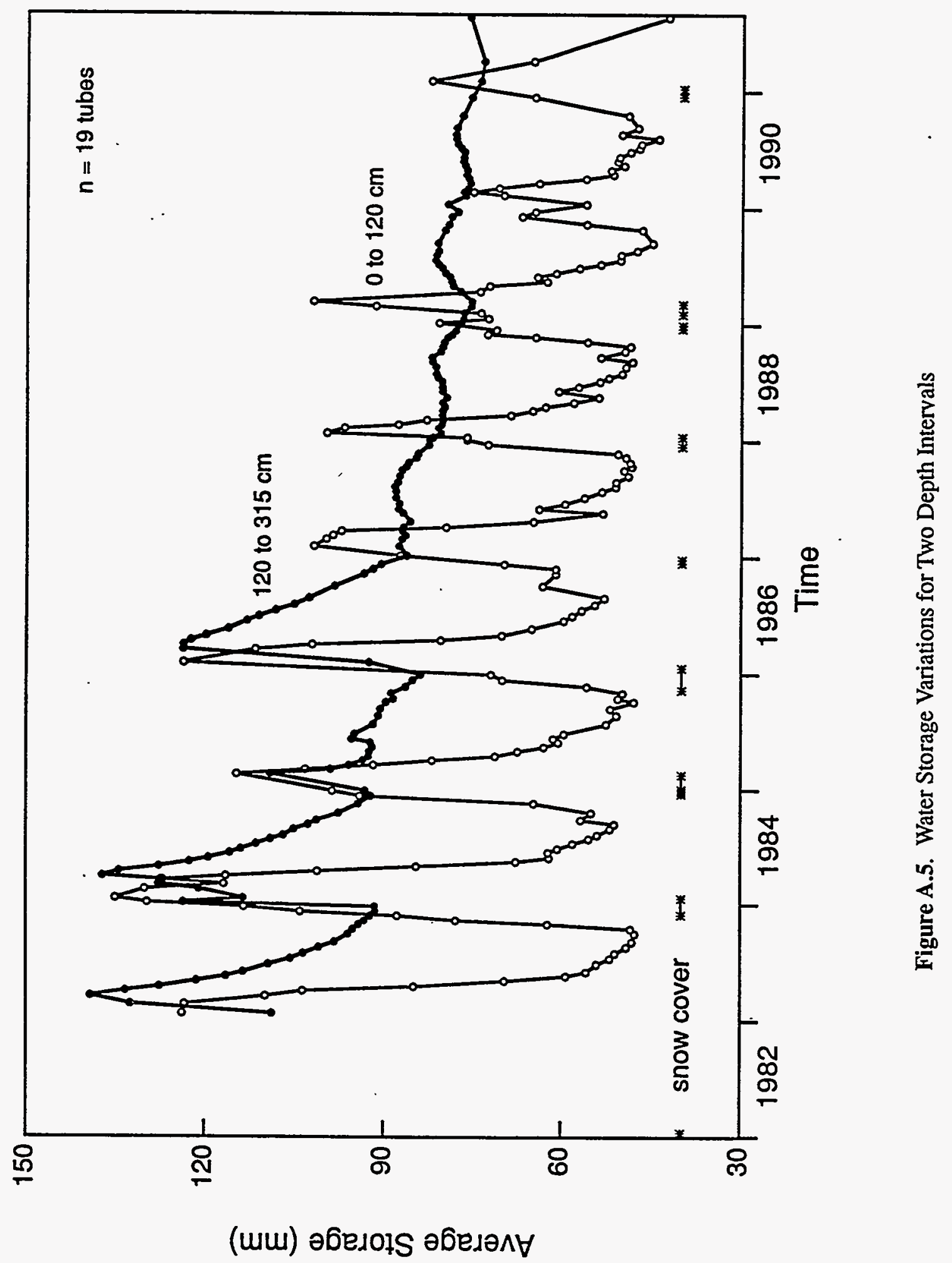


40 to $130 \mathrm{~mm}$ in response to weather. Storage between 120 and $315 \mathrm{~cm}$ varied somewhat less, ranging from 75 to $140 \mathrm{~mm}$. Interestingly, peak storage values below $120 \mathrm{~cm}$ occurred whenever storage above $120 \mathrm{~cm}$ exceeded about $100 \mathrm{~mm}$.

Equation A.1 was used to estimate recharge for each year using storage values calculated from 'the average water content at each depth $(n=19)$. The example in Figure A.1 showed the calculation for the year 1984. Table A.1 shows that the resulting recharge estimates are quite high for the first four years, and much lower for the second four years. This result coincides with the change in precipitation and air temperature in Figure A.4.

Estimated recharge ranged from 5.6 to $53.1 \mathrm{~mm} / \mathrm{yr}$ over the eight years of record. When recharge was high, storage peaks occurred in February and March. When recharge was low, storage peaks occurred between July and September. Despite warmer and drier than normal weather from 1987 to 1990, recharge was still evident, although the rates were lower and partially reflect drainage of previously stored water. This period of decreasing recharge did not last. An isolated set of three measurements in the spring of 1993 revealed that storage in the $120-$ to $315-\mathrm{cm}$ zone had increased to $139.9 \mathrm{~mm}$. This value is similar to the storage value in 1983 , when recharge was calculated to be $53.1 \mathrm{~mm}$ for that year.

Equation A.1 was also used to estimate recharge for each access tube. The results show that recharge was spatially variable. Depending on the year, the highest value was from 2 to $28 \mathrm{x}$ the lowest value. While some tubes tended to always have higher or lower rates, no consistent pattern or ranking emerged. This observation is in accord with statements by Gee et al. (1989), who determined that the ranking of the tubes (relative to the amount of storage) did not remain stable over time.

Table A.1. Recharge Rates Estimated with Equation A.1

\begin{tabular}{||c|c|c|c|c||}
\hline \multirow{2}{*}{ Year } & \multirow{3}{*}{ Estimated Recharge (mm/yr) } \\
\cline { 3 - 5 } & Average Tube & Average & Low & High \\
\hline \hline 1983 & 47.6 & 53.1 & 36.5 & 77.5 \\
\hline 1984 & 44.7 & 52.1 & 31.4 & 74.6 \\
\hline 1985 & 25.2 & 24.5 & 5.1 & 143.5 \\
\hline 1986 & 37.3 & 43.0 & 17.9 & 67.0 \\
\hline 1987 & 8.7 & 9.8 & 7.1 & 14.5 \\
\hline 1988 & 6.6 & 7.8 & 5.6 & 10.7 \\
\hline 1989 & 5.8 & 7.2 & 4.2 & 10.2 \\
\hline 1990 & 4.7 & 5.6 & 3.0 & 7.5 \\
\hline 8 8-yr Avg. & 22.6 & 25.4 & 13.9 & 50.7 \\
\hline
\end{tabular}


When the recharge estimates from the individual tubes were averaged for each year, the average estimated rates were $12 \%$ higher than the rates calculated from averaged water contents. Averaging. of water contents before calculating storage smoothed some of the seasonal variation, resulting in lower recharge estimates.

In Table A.1, the large difference between the lowest and highest rates in 1985 indicates much higher recharge variability than in the other years. Figure A.6 shows that one week after a quick snowmelt in February 1985, significantly higher water contents were detected in four of the access tubes, relative to the other tubes. Figure A.7 shows the variation in water content at 120-, 225-, and $315-\mathrm{cm}$ depths during this period. Figure A.8 shows the variation in storage between the two sets of tubes. During the snowmelt, water ponded on the surface at another site $3 \mathrm{~km}$ away and lasted about one day before completely infiltrating (Jones 1989). Similar ponding likely occurred at the Grass Site, resulting in significantly higher infiltration and recharge $(84.5 \mathrm{~mm}$ ) around the four tubes, compared to the recharge observed for the other 15 tubes $(8.5 \mathrm{~mm})$. These results highlight the small scales (i.e., $6 \mathrm{~m}$ or less) over which recharge rates can differ substantially. With a sparser sampling network, these events could have escaped detection. The rapidity of movement of some of the pulses of infiltrating water indicates a need to monitor more frequently during likely recharge events, i.e., during and after snowmelts.

The eight-year average estimated recharge rate is $25.4 \mathrm{~mm} / \mathrm{yr}$. Based on the yearly estimates in Table A.1, eight years was insufficient to produce a long-term average such as the 30-year averages used in meteorology to describe precipitation and air temperature means. An alternative is to extrapolate based on observed behavior. The estimated recharge rates were regressed on the precipitation received during the previous November through.January. This regression equation $\left(r^{2}=0.916\right)$ was then applied to the historical precipitation record for 1951 to 1980 . The average of the regression-estimated recharge rates was $25.0 \mathrm{~mm} / \mathrm{yr}$, which is similar to what was measured over the eight-year period from 1983 to 1990 . This regression is applicable only if, during much of the time from 1951 to 1980 , the Grass Site was covered with similar vegetation.

\section{References}

Allison, G. B., G. W. Gee, and S. W. Tyler. 1994. "Vadose-Zone Techniques for Estimating Groundwater Recharge in Arid and Semiarid Regions." Soil Sci. Soc. Am. J. 58:6-14.

Gee, G. W., and R. R. Kirkham. 1984. Arid Site Water Balance: Evapotranspiration Modeling and Measurements. PNL-5177, Pacific Northwest Laboratory, Richland, Washington.

Gee, G. W., M. L. Rockhold, and J. L. Downs. 1989. Status of FY 1988 Soil-Water Balance Studies on the Hanford Site. PNL-6750, Pacific Northwest Laboratory, Richland, Washington.

Hoitink, D. J., and K. W. Burk. 1994. Climatological Data Summary 1993 with Historical Data. PNL-9809, Pacific Northwest Laboratory, Richland, Washington.

Jones, T. L. 1989. Simulating the Water Balance of an Arid Site. PNL-SA-17633, Pacific Northwest Laboratory, Richland, Washington. 


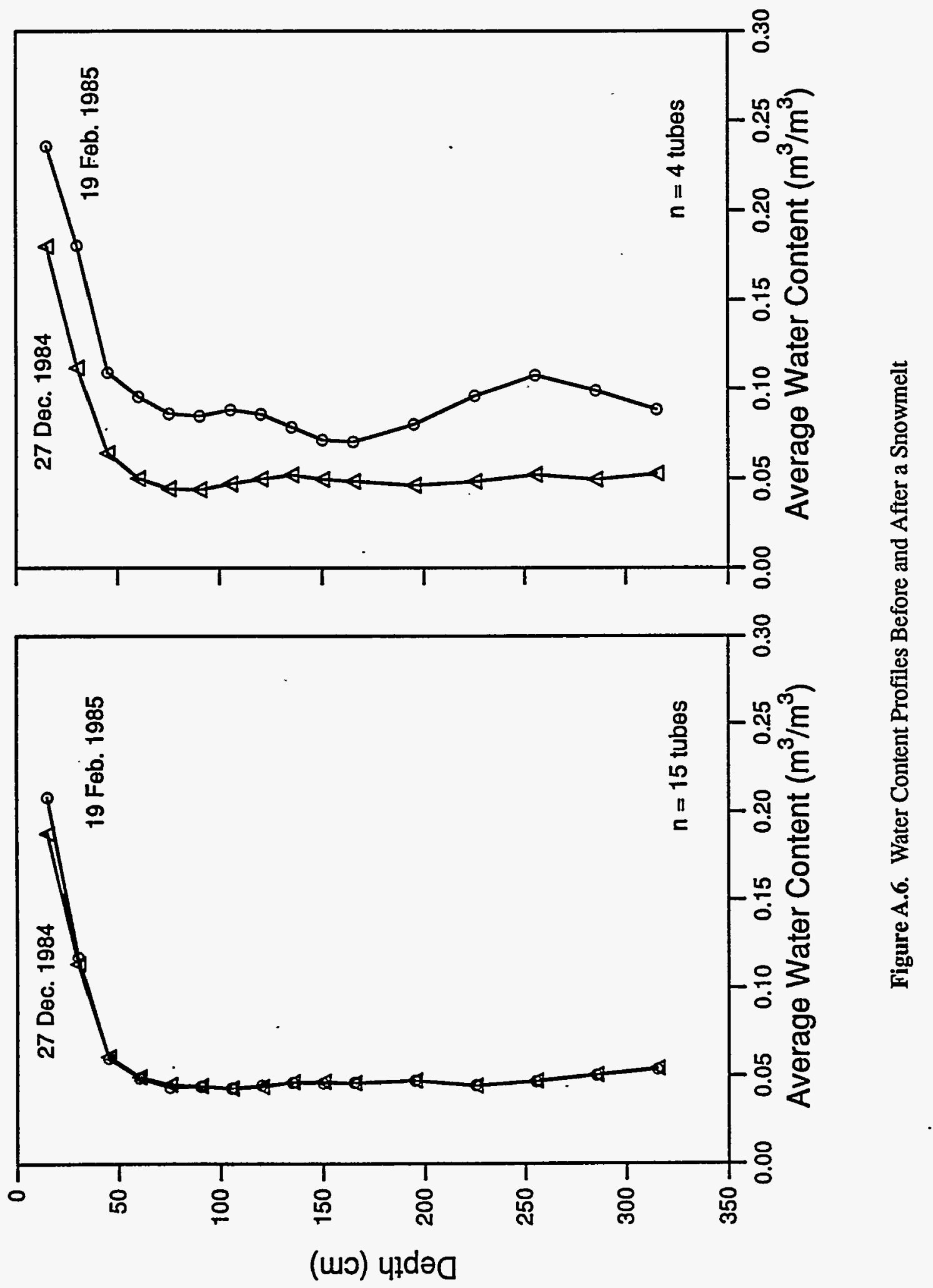

\section{A.11}




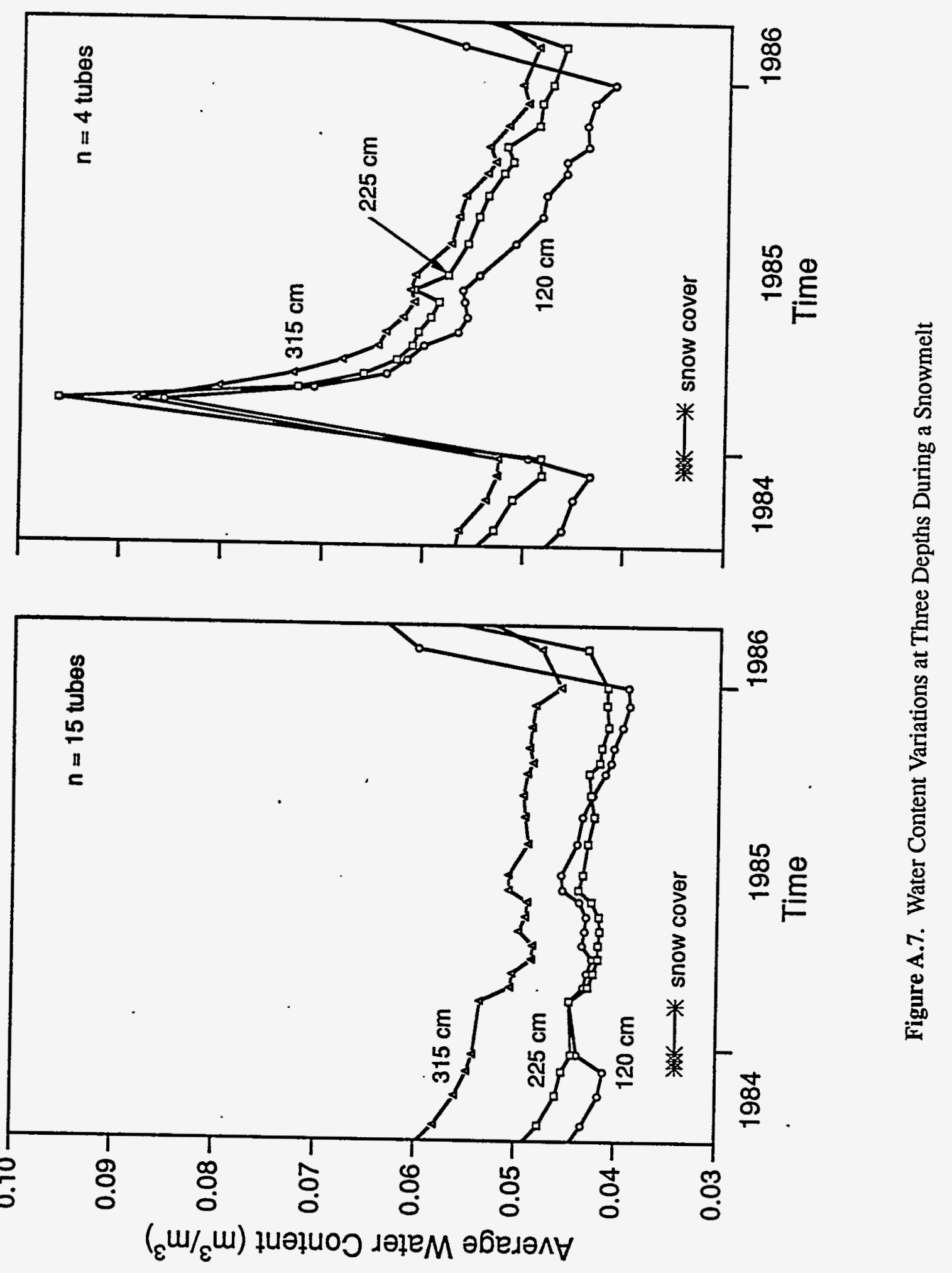

A.12 


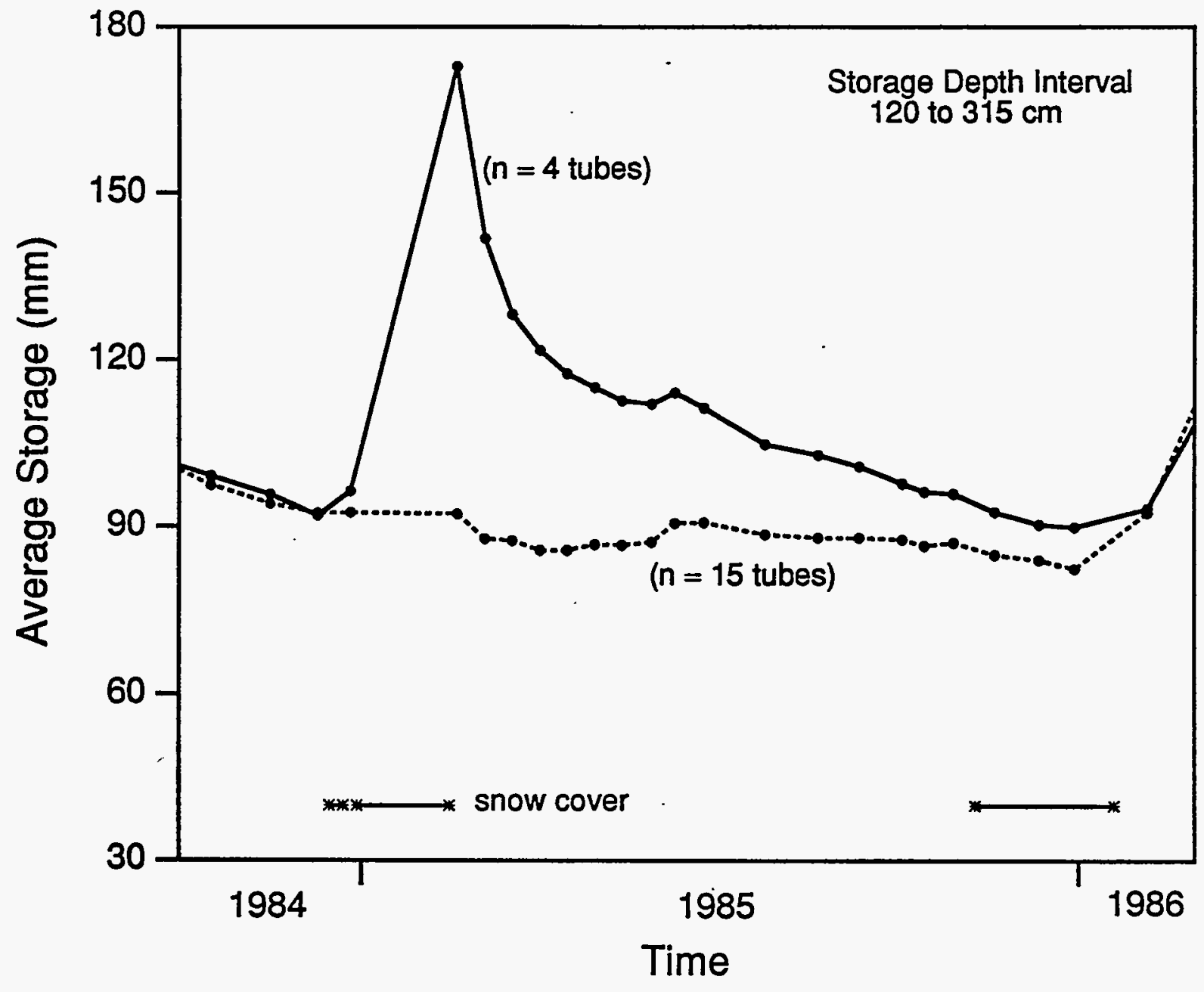

Figure A.8. Water Storage Variations for Two Depth Intervals During a Snowmelt 
Link, S. O., G. W. Gee, and J. L. Downs. 1990. "The Effect of Water Stress on Phenological and Ecophysiological Characteristics of Cheatgrass and Sandberg's Bluegrass." J. Range Mgmt. 43:506-513.

Reece, C. F. 1991. Sparse Plant Community Effects on Soil Water Balance of an Arid Site. Ph. D. Diss., Washington State University, Pullman, Washington.

Rockhold, M. L., M. J. Fayer, G. W. Gee, and M. J. Kanyid. 1990. Natural Groundwater Recharge and Water Balance at the Hanford Site. PNL-7215, Pacific Northwest Laboratory, Richland, Washington.

Stone, W. A., J. M. Thorp, O. P. Gifford, and D. J. Hoitink. 1983. Climatological Summary for the Hanford Area. PNL-4622, Pacific Northwest Laboratory, Richland, Washington. 


\section{Appendix B}

\section{Computer Simulations}




\section{Appendix B}

\section{Computer Simulations}

The computer code-UNSAT-H Version 2.0 (Fayer and Jones 1990) was modified to run on a unix workstation and used to estimate recharge rates. UNSAT-H is a one-dimensional model that simulates the dynamic processes of infiltration, drainage, redistribution, surface evaporation, and the uptake of water from soil by plants. Simulations were conducted for 12 combinations involving five soil types (Warden silt loam, Ephrata sandy loam, Burbank loamy sand, Hezel sand, and Rupert sand) and four cover types (shrub, bunchgrass, cheatgrass, and no vegetation). These 12 combinations were chosen for simulation because no field data (i.e., drainage, water contents, or tracers) existed to estimate recharge. For all simulations, water flow was isothermal, vapor flow was included, and the hydraulic properties were nonhysteretic. The input parameters are specified below; a discussion of the results follows.

\section{B.1 Input Parameters}

The input parameters for each simulation include a description of the model domain and node spacing, soil hydraulic properties, initial suction heads, boundary conditions, and plant information. Figures B.1 through B.5 contain pertinent portions of the input files used to simulate recharge rates. The meteorological data are not shown but were identical for all simulations.

\section{B.1.1 Model Domain}

In all cases, the model domain was $4 \mathrm{~m}$ deep. Each domain was discretized to provide an acceptable solution. The node spacing at the surface was always $0.2 \mathrm{~cm}$; at the deepest depths, the spacing ranged from 25 to $70 \mathrm{~cm}$. At the interfaces of differing materials, the node spacing was gradually reduced to $2 \mathrm{~cm}$.

\section{B.1.2 Soil Hydraulic Properties}

Each soil profile was described using information from Kocher and Strahorn (1919), Hajek (1966), and the soil survey for Benton County that was produced by the U.S. Department of Agriculture (USDA 1971). The soil survey by the USDA (1971) does not cover the Hanford Site or the City of Richland, but many of the soils are the same. Although many variations of each soil type are known to exist, no map of these variations is known to exist. Therefore, a single average soil profile was defined for each soil type that was simulated.

The depth to bedrock of the Warden silt loam was reported to range from 102 to more than $152 \mathrm{~cm}$. For these simulations, the Warden silt loam was treated as a uniform silt loam profile for the entire 4-m model domain. Hydraulic properties were described with the fourth data set in Table 4.5 of Rockhold et al. (1988).

The Ephrata sandy loam description in Hajek (1966) was insufficient to describe soil profile layering. Based on Kocher and Strahorn (1919), the Ephrata sandy loam is likely a Finley fine sandy loam as described in USDA (1971). The soil profile was established with a sandy loam from the soil surface to $33 \mathrm{~cm}$, a gravelly loam from 33 to $71 \mathrm{~cm}$, and a sandy gravel below $71 \mathrm{~cm}$. The properties 


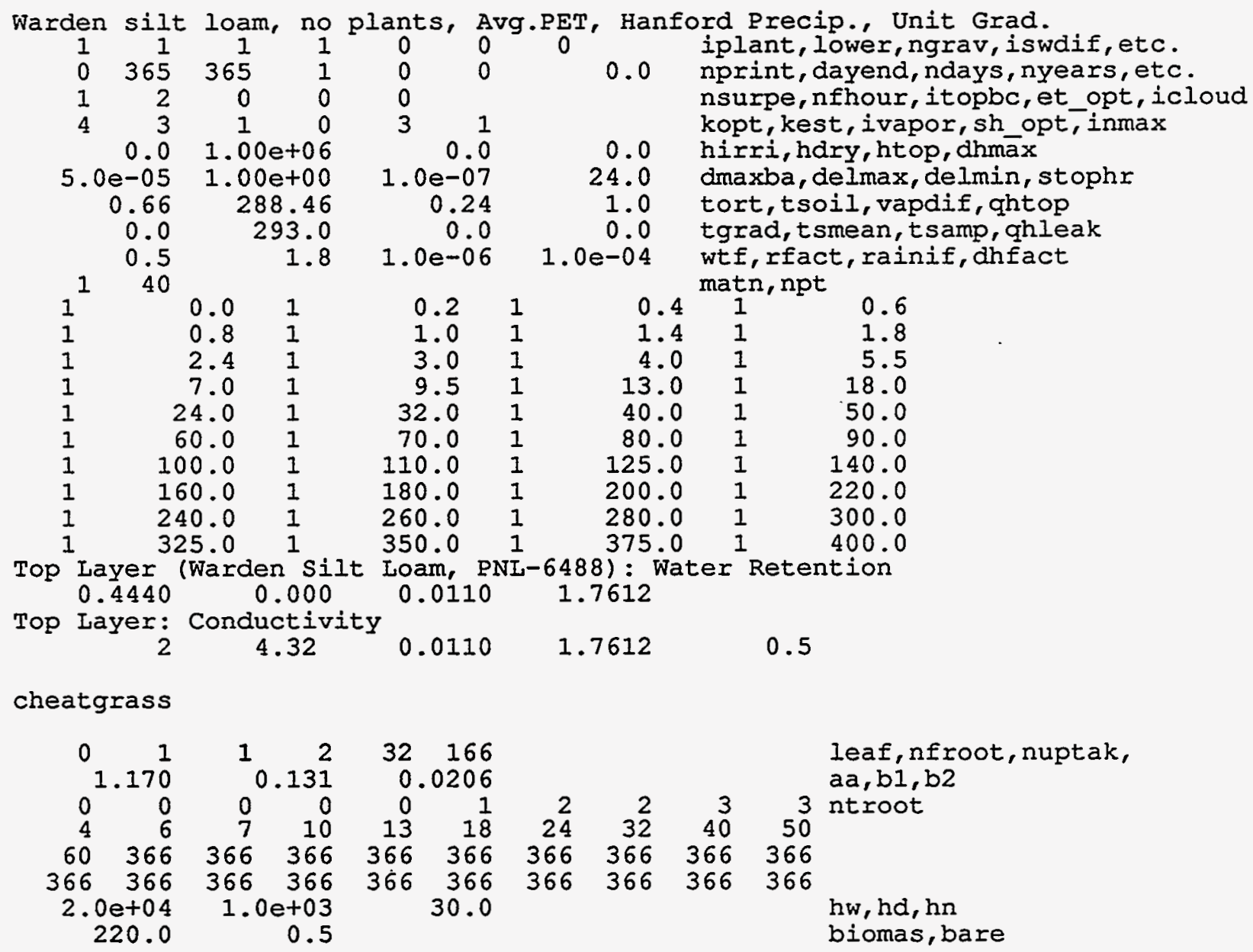

Figure B.1. Portions of the UNSAT-H Input Files Used to Simulate the Warden Silt Loam 


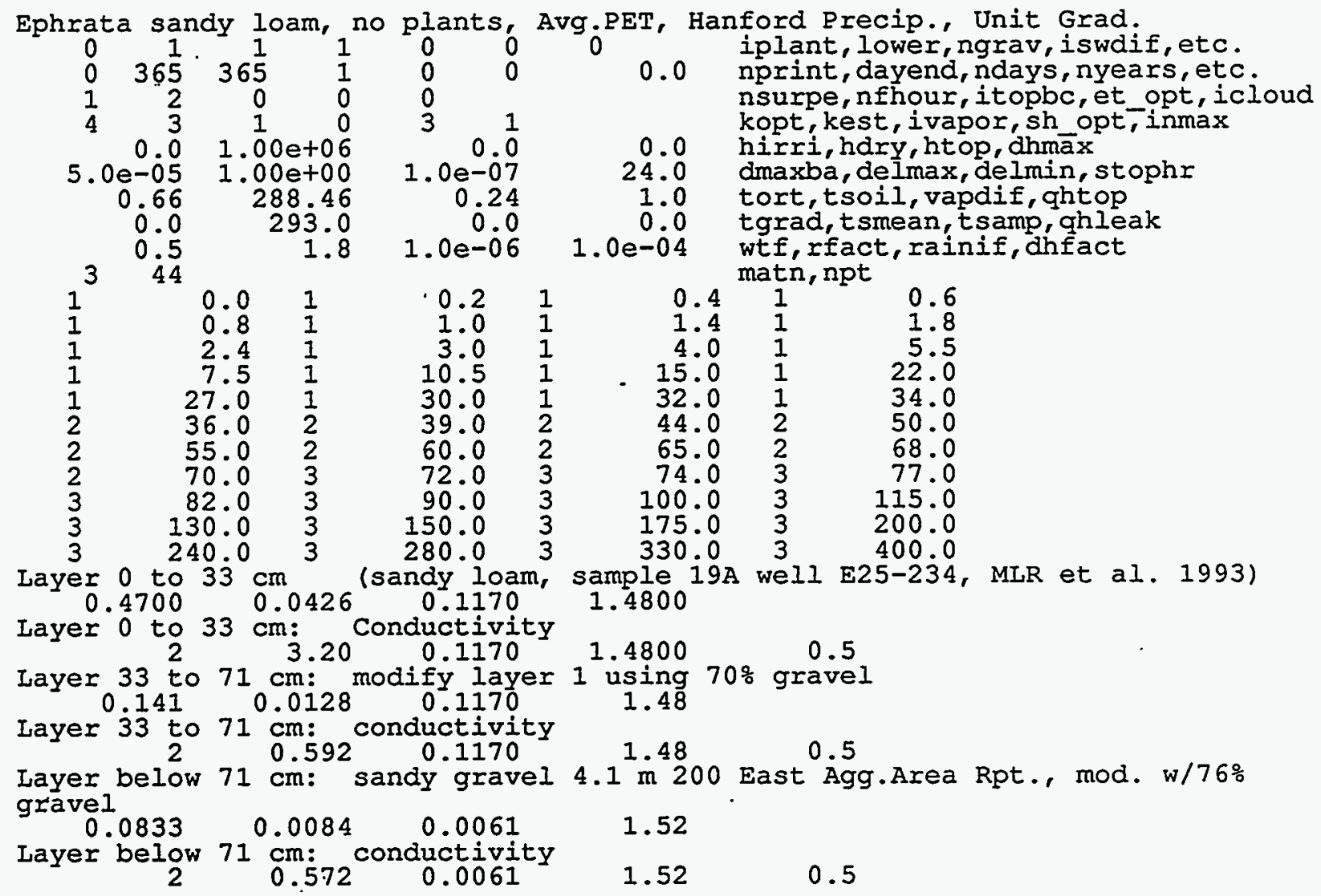

cheatgrass

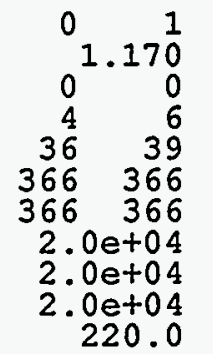

$$
\begin{array}{rr}
1 & 2 \\
0.131 \\
0 & 0 \\
8 & 11 \\
44 & 50 \\
366 & 366 \\
366 & 366 \\
1.0 e+03 \\
1.0 e+03 \\
1.0 e+03 \\
0.5
\end{array}
$$

32
0.0206

$\begin{array}{rr}0 & 1 \\ 15 & 22 \\ 55 & 60 \\ 366 & 366\end{array}$

30.0

30.0

30.0

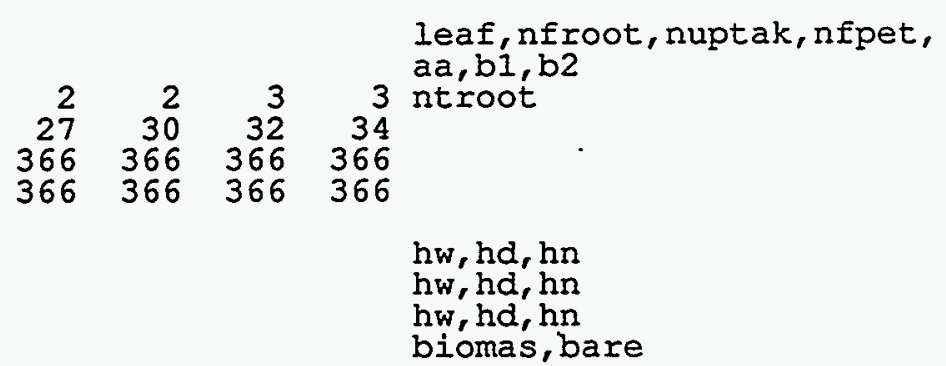

bunchgrass

$$
\begin{array}{rr}
1 & 1 \\
6 & 0.5 \\
0 & 0.0 \\
366 & 0.0 \\
\multicolumn{2}{c}{0.315} \\
0 & 0 \\
0 & 0 \\
0 & 0 \\
0 & 0 \\
366 & 366 \\
4.0 e+04 \\
4.0 e+04 \\
4.0 e+04
\end{array}
$$

$\begin{array}{ll}60 & 166\end{array}$ $\begin{array}{ll}90 & 0.4\end{array}$

0.0755
0

$\begin{array}{rr}0 & 0 \\ 0 & 0 \\ 0 & 0 \\ 0 & 366\end{array}$

30.0

30.0 leaf, nfroot, nuptak, nfpet, npoint, bare

$\begin{array}{lllll}150 & 0.4 & 166 & 0.0 & \text { ngrow, flai }\end{array}$

ngrow, flai

$a a, b 1, b 2$

$\begin{array}{rrrrr}0 & 0 & 0 & 0 & \text { ntroot } \\ 0 & 0 & 0 & 0 & \\ 0 & 0 & 0 & 0 \\ 366 & 366 & 366 & 366\end{array}$

hw, hd, hn

hw, hd, hn

hw, hd, hn

Figure B.2. Portions of the UNSAT-H Input Files Used to Simulate the Ephrata Sandy Loam 


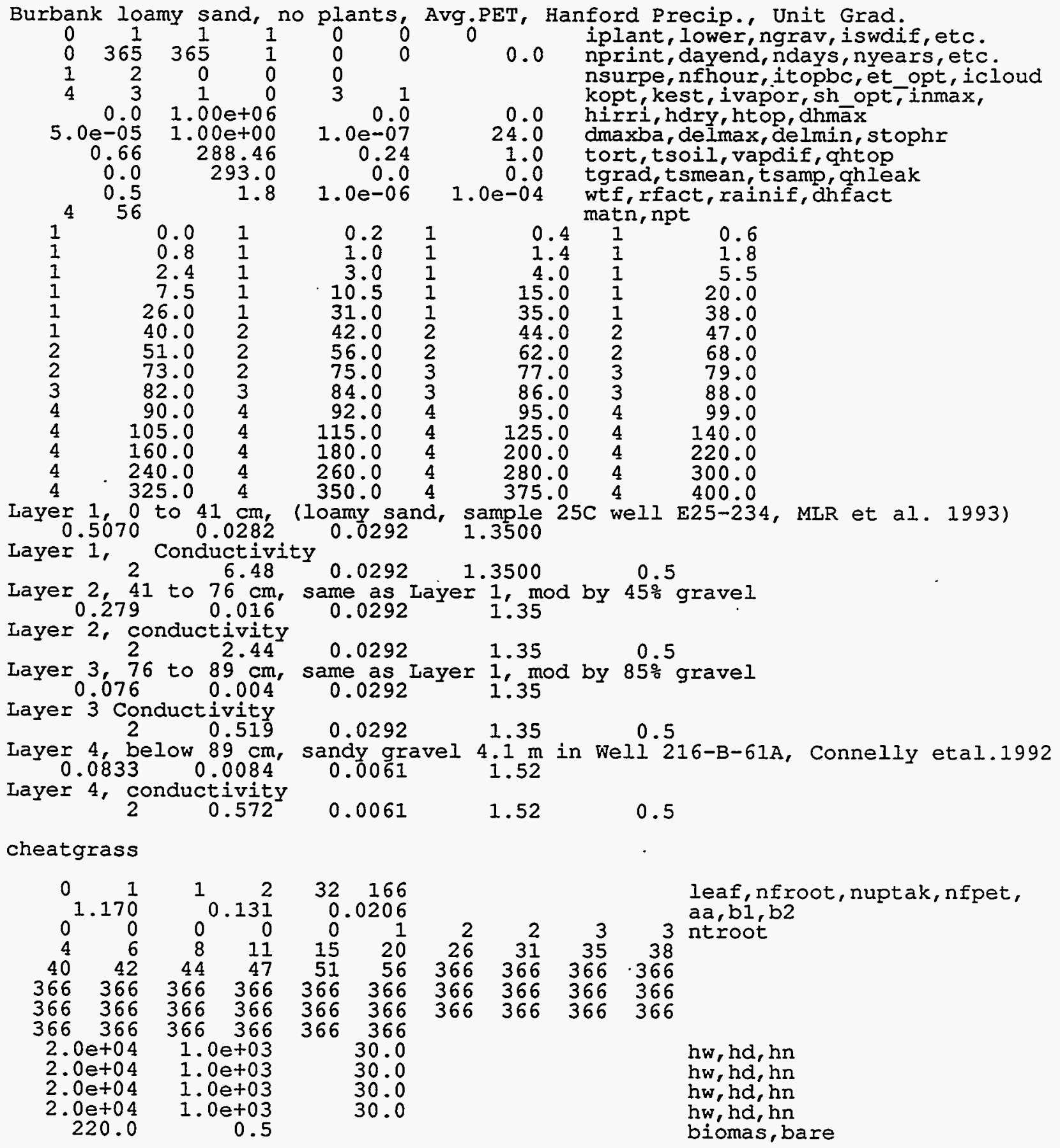

Figure B.3. Portions of the UNSAT-H Input Files Used to Simulate the Burbank Loamy Sand 


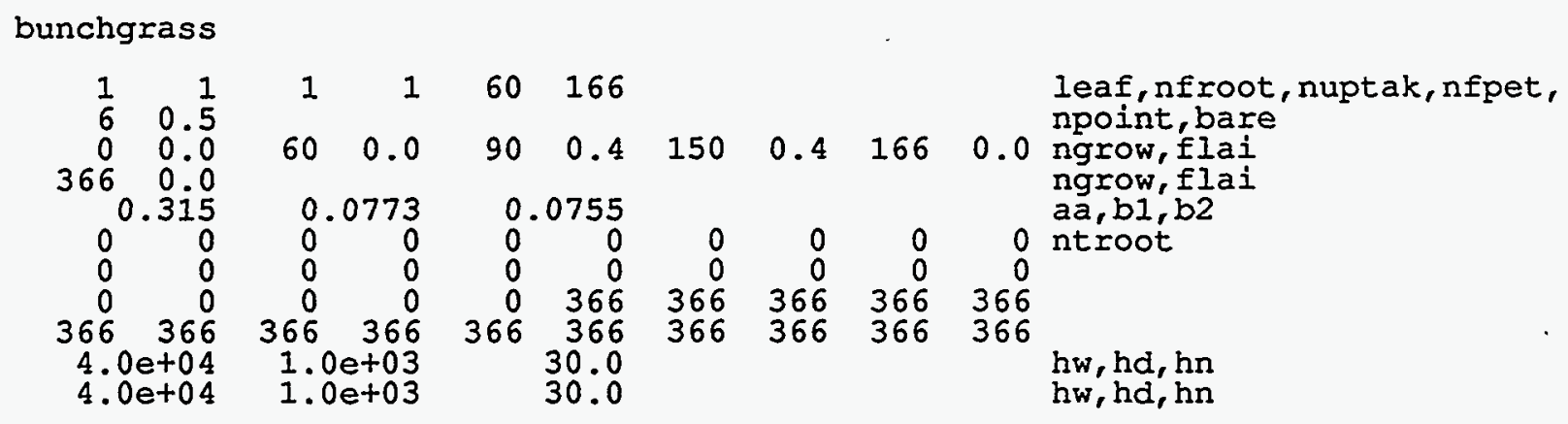

Figure B.3. (contd) 


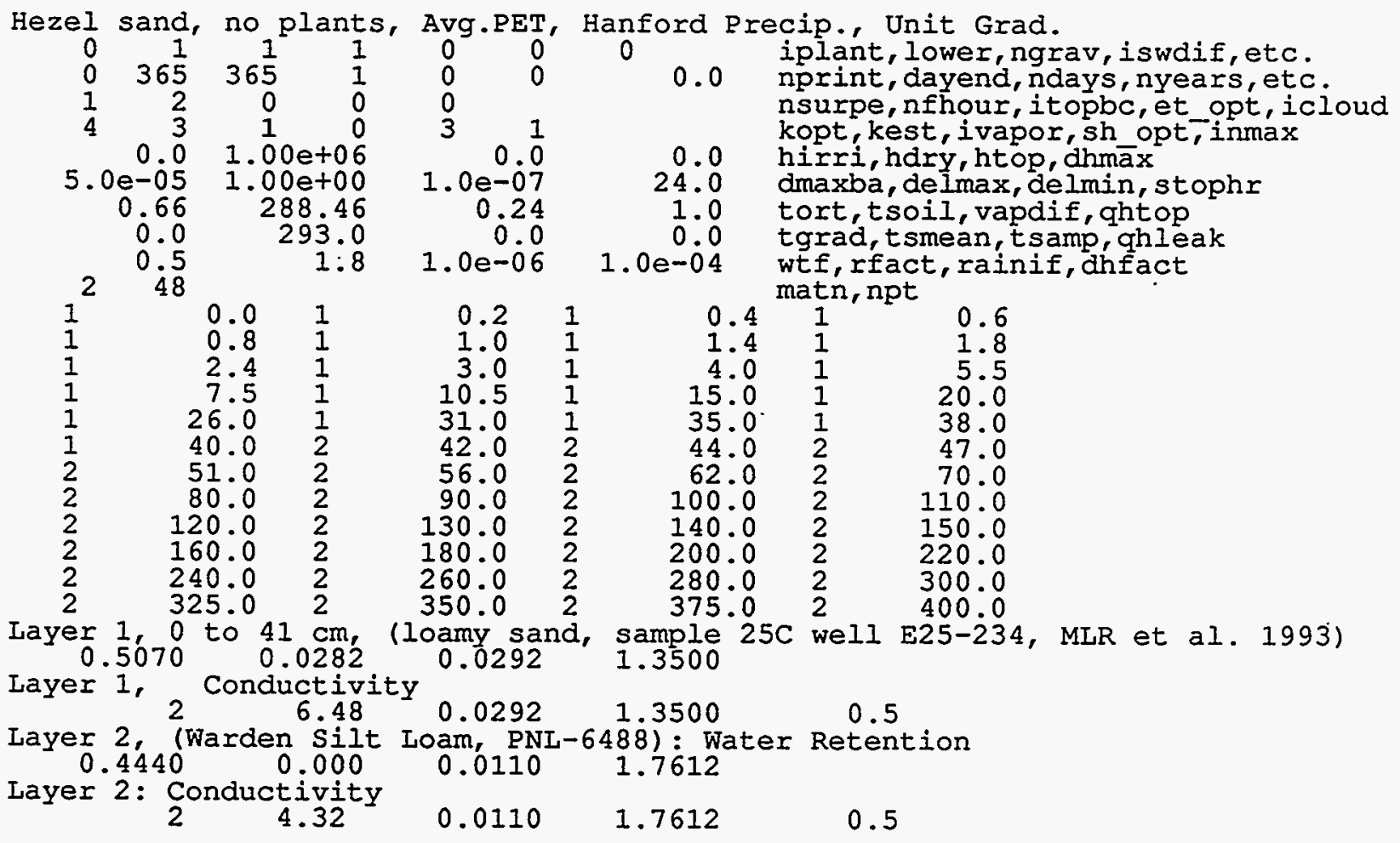

cheatgrass

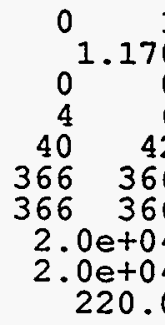

$$
\begin{array}{rrrr}
1 & 2 & 32 & 166 \\
0.131 & 0.0206 \\
0 & 0 & 0 & 1 \\
8 & 11 & 15 & 20 \\
44 & 47 & 51 & 56 \\
366 & 366 & 366 & 366 \\
366 & 366 & 366 & 366 \\
1.0 e+03 & & 30.0 \\
1.0 e+03 & & 30.0 \\
0.5 & &
\end{array}
$$

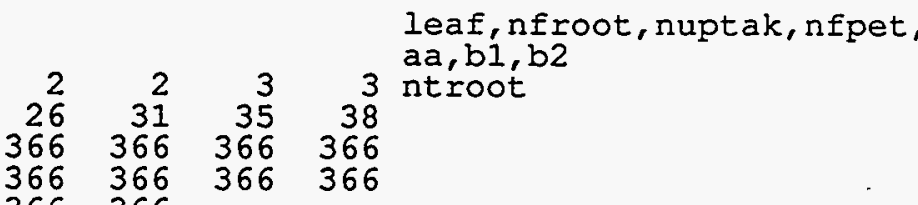

bunchgrass

$$
\begin{array}{rr}
1 & 1 \\
6 & 0.5 \\
0 & 0.0 \\
366 & 0.0 \\
\multicolumn{2}{c}{0.315} \\
0 & 0 \\
0 & 0 \\
0 & 0 \\
0 & 366 \\
366 & 366 \\
4.0 e+04 \\
4.0 e+04
\end{array}
$$

$$
\begin{array}{rr}
1 & 1 \\
60 & 0.0 \\
0.0773 \\
0 & 0 \\
0 & 0 \\
0 & 0 \\
366 & 366 \\
366 & 366 \\
1.0 e+03 \\
1.0 \mathrm{e}+03
\end{array}
$$$$
60166
$$$$
90 \quad 0.4 \quad 150
$$$$
0.4 \quad 166
$$$$
0.0
$$
leaf, nfroot, nuptak, nfpet, npoint, bare

$\mathrm{hw}, \mathrm{hd}, \mathrm{hn}$

hw, hd, hn

biomas, bare

$$
\begin{array}{rr}
0.0755 \\
0 & 0 \\
0 & 0 \\
0 & 0 \\
366 & 366 \\
366 & 366 \\
& 30.0 \\
& 30.0
\end{array}
$$

ngrow, flai

$$
\mathrm{aa}, \mathrm{b} 1, \mathrm{~b} 2
$$

ntroot

$\begin{array}{rrrr}0 & 0 & 0 & 0 \\ 0 & 0 & 0 & 0 \\ 0 & 0 & 0 & 0 \\ 366 & 366 & 366 & 366\end{array}$

hw, hd, hn

hw, hd, hn

Figure B.4. Portions of the UNSAT-H Input Files Used to Simulate the Hezel Sand 


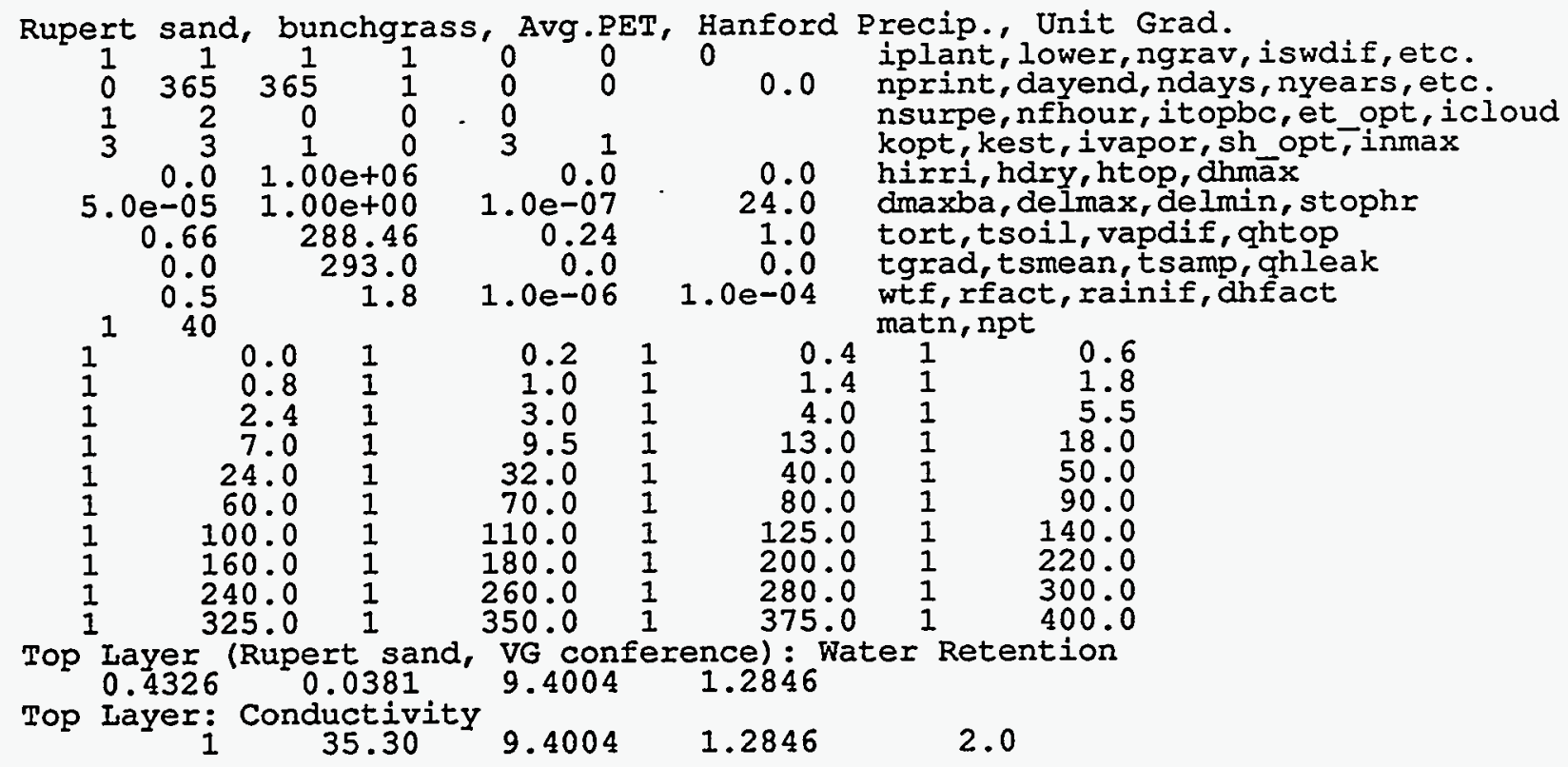

bunchgrass

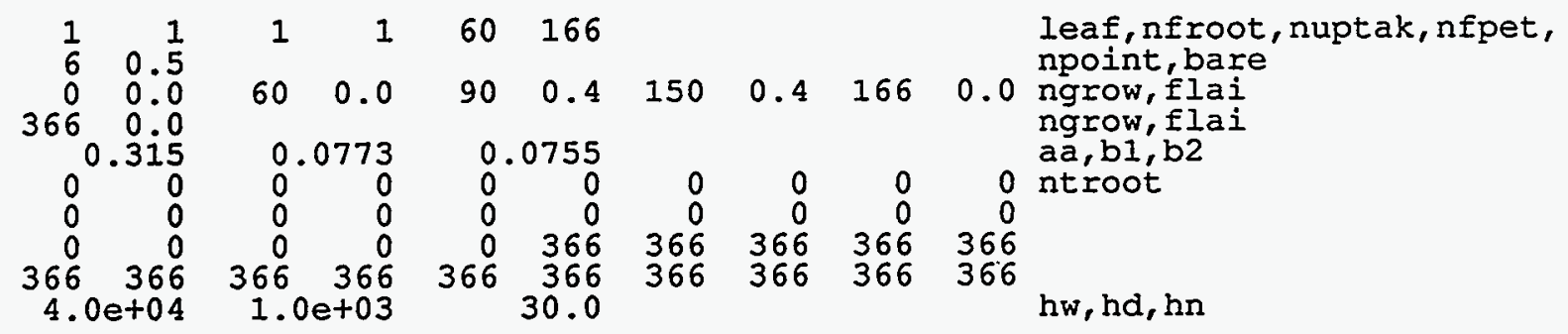

shrub

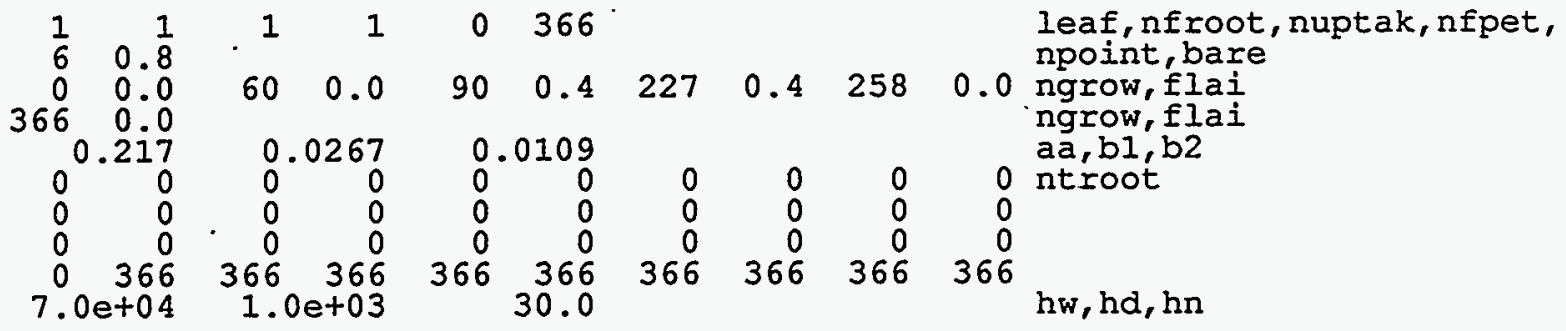

Figure B.5. Portions of the UNSAT-H Input Files Used to Simulate the Rupert Sand 
for the sandy loam were specified to be those of Sample 19A (a sandy loam) in Rockhold et al. (1993). For the gravelly loam layer, the sandy loam properties were used, but were scaled based on the gravel content. According to the soil survey, the gravel content of the gravelly loam ranged from 60 to $80 \%$. For the simulations, a gravel content of $70 \%$ was assumed. The gravel scaling equations were described in Rockhold et al. (1993). For the sandy gravel layer, the hydraulic properties of the sample (a sandy gravel) from the 4.1-m depth in Well 216-B-61-A were used (p. A-55 of Connelly et al. 1992). This sample was referred to as sandy gravel, and the particle size distribution (p. A-56 of Connelly et al. 1992) show it to contain $76 \%$ gravel. Therefore, the hydraulic properties were scaled to account for the gravel.

The Burbank loamy sand, as described in the USDA (1971) soil survey, consists of loamy sand from the soil surface to $41 \mathrm{~cm}$, gravelly loamy sand (45\% gravel) from 41 to $76 \mathrm{~cm}$, very gravelly loamy sand (85\% gravel) from 76 to $89 \mathrm{~cm}$, and sand and gravel below $89 \mathrm{~cm}$. The hydraulic properties of the surface layer of loamy sand were described using the properties for Sample $25 \mathrm{C}$ (a loamy sand) from Rockhold et al. (1993). The properties of the second and third layers were obtained by scaling the surface loamy sand properties using the gravel percentages of each layer. For the fourth layer, the sand and gravel properties were represented with the properties of the bottom layer (a sandy gravel) used in the Ephrata sandy loam soil profile.

The Hezel sand, as described in the USDA (1971) soil survey, consists of loamy very fine sand from the soil surface to $41 \mathrm{~cm}$, and silt loam below $41 \mathrm{~cm}$. The properties of the surface loamy very fine sand were represented using the properties of the top layer of the Burbank loamy sand. The properties of the lower silt loam were represented with the properties of the silt loam in the Warden silt loam profile.

The Rupert sand that was identified by Hajek (1966) was known as Winchester sand (or fine sand) in Kocher and Strahorn (1919) and is known as Quincy sand in USDA (1971). In all cases, the soil profile is a very deep sand and so, for the simulations, the entire $4 \mathrm{~m}$ were represented as sand. The hydraulic properties of this sand were represented using the properties reported in Fayer and Gee (1992) for the sand in the lysimeters at the Buried Waste Test Facility.

The hydraulic properties of each of the layers in the five soil profiles are shown in Figures B.6 to B.9. For most layers, soil water retention was described with the van Genuchten function and hydraulic conductivity was described with the Mualem conductivity model. For the Rupert sand, soil water retention was described with the Brooks-Corey function, and hydraulic conductivity was described with the Burdine conductivity model. Table B.1 lists the parameters. Also included in Table B.1 are permeability values for each layer as reported by the USDA (1971). These values were not used in the simulations but were included to demonstrate possible discrepancies in soil properties. The values for the Warden silt loam and Rupert sand are very similar to those used in the simulations. The values for the Hezel sand are within a factor of four. In contrast, the values for the Ephrata sandy loam and Burbank loamy sand are very different. For most layers, the USDA values are 10x to $50 \mathrm{x}$ higher than the conductivity values used in the simulations. This discrepancy was not addressed in this report.

\section{B.1.3. Initial Suction Heads}

The 1957 suction head values were not available for these soil profiles. In lieu of this information, the initial conditions were assumed to be suction head values of $1,000 \mathrm{~cm}$. This initial value was reasonably dry and was expected to hạve little influence beyond 1 to 2 simulation years. 

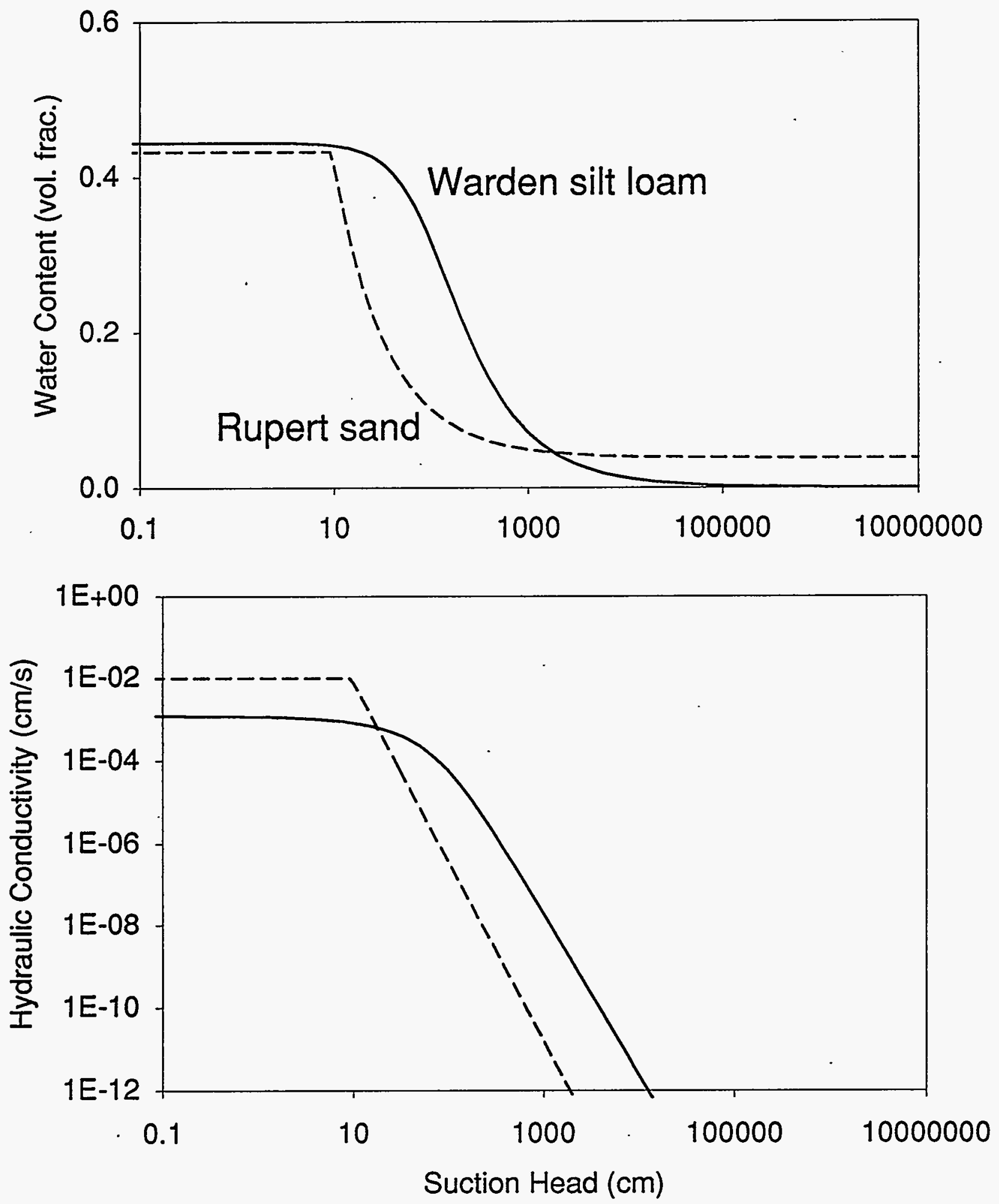

Figure B.6. Soil Water Retention and Hydraulic Conductivity of Materials Used to Simulate the Warden Silt Loam and Rupert Sand 

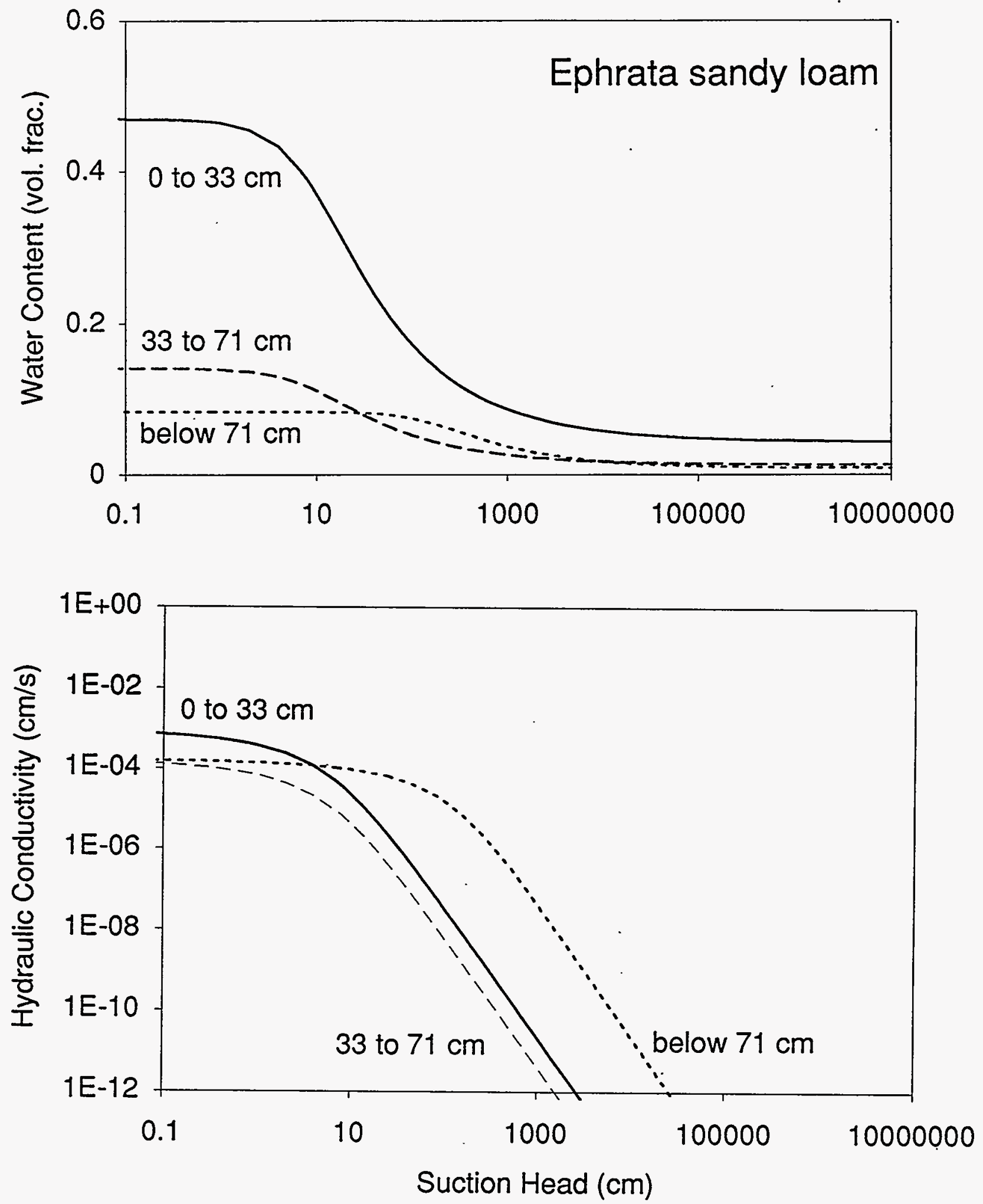

Figure B.7. Soil Water Retention and Hydraulic Conductivity of Materials Used to Simulate the Ephrata Sandy Loam 

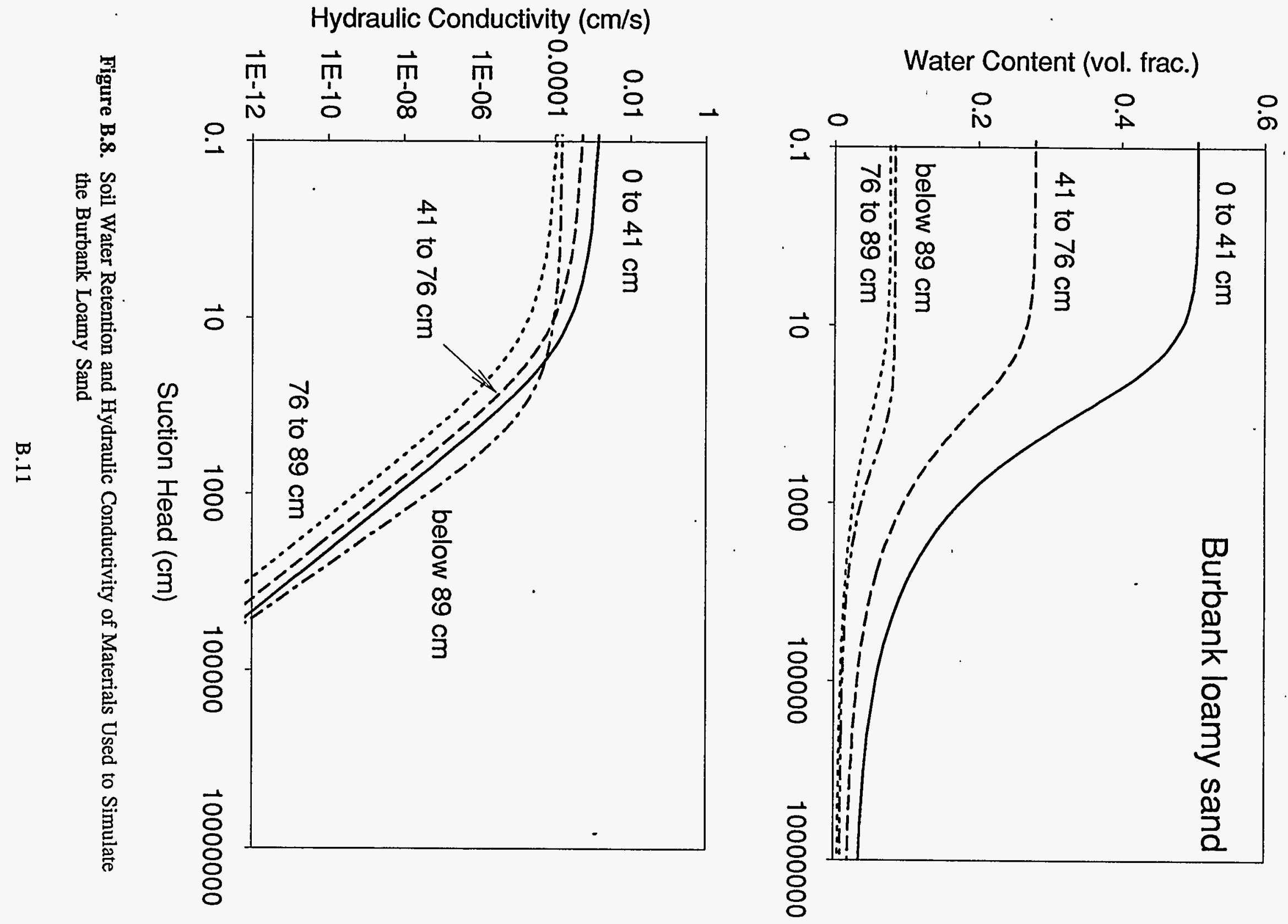

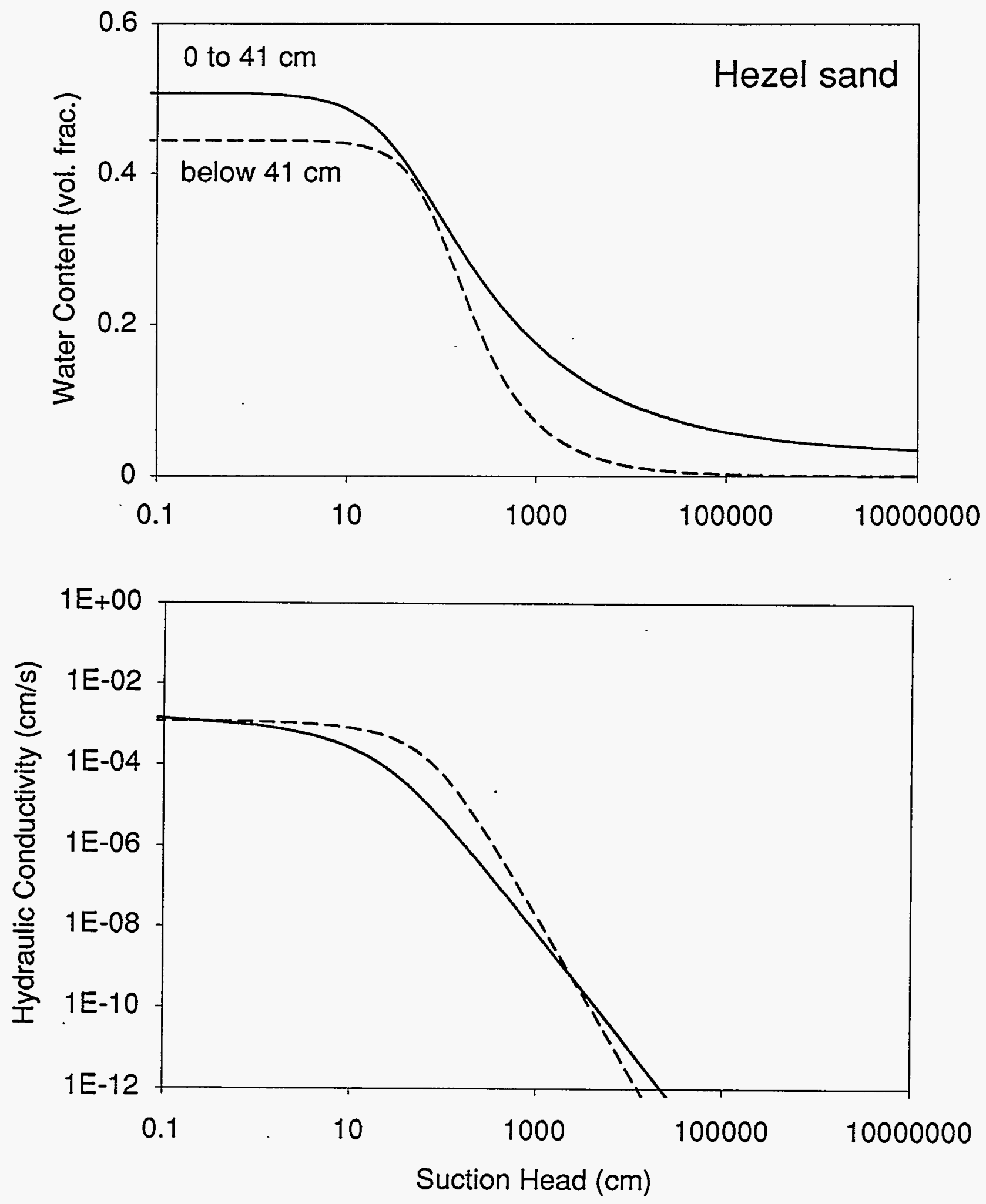

Figure B.9. Soil Water Retention and Hydraulic Conductivity of Materials Used to Simulate the Hezel Sand

B. 12 
Table B.1. Parameters used to describe soil hydraulic properties in the simulations. The van Genuchten parameter $m$ was set equal 1-1/n. The standard pore interaction terms were used.

\begin{tabular}{|c|c|c|c|c|c|c|c|c|}
\hline Soil Type and Depths & $\begin{array}{c}\theta_{s} \\
\mathrm{~m}^{3} / \mathrm{m}^{3}\end{array}$ & $\begin{array}{c}\theta_{\mathrm{r}} \\
\mathrm{m}^{3} / \mathrm{m}^{3}\end{array}$ & $\begin{array}{c}\alpha \\
1 / \mathrm{cm}\end{array}$ & $\begin{array}{l}\mathbf{n} \\
-\end{array}$ & $\begin{array}{c}\mathrm{K}_{\mathrm{s}} \\
\mathrm{cm} / \mathrm{h}\end{array}$ & $\begin{array}{l}b \\
-\end{array}$ & $\begin{array}{l}\mathrm{h}_{\mathrm{e}} \\
\mathrm{cm}\end{array}$ & $\begin{array}{c}\text { USDA } \\
\text { Permeability } \\
\mathrm{cm} / \mathrm{h}\end{array}$ \\
\hline \multicolumn{9}{|l|}{ Warden silt loam } \\
\hline 0 to 400 & 0.444 & 0.0 & 0.011 & 1.76 & 4.32 & - & - & $2.03-6.35$ \\
\hline \multicolumn{9}{|l|}{ Ephrata sandy loam } \\
\hline 0 to 33 & 0.470 & 0.0426 & 0.117 & 1.48 & 3.20 & - & - & $6.35-12.7$ \\
\hline 33 to 71 & 0.141 & 0.0128 & 0.117 & 1.48 & 0.592 & - & - & $6.35-12.7$ \\
\hline 71 to 400 & 0.0833 & 0.0084 & 0.0061 & 1.52 & 0.572 & - & - & $>25.4$ \\
\hline \multicolumn{9}{|l|}{ Burbank loamy sand } \\
\hline 0 to 41 & 0.507 & 0.0282 & 0.0292 & 1.35 & 6.48 & - & - & $>25.4$ \\
\hline 41 to 76 & 0.279 & 0.0160 & 0.0292 & 1.35 & 2.44 & - & - & $>25.4$ \\
\hline 76 to 89 & 0.0760 & 0.0040 & 0.0292 & 1.35 & 0.519 & - & - & $>25.4$ \\
\hline 89 to 400 & 0.0833 & 0.0084 & 0.0061 & 1.52 & 0.572 & - & - & $>25.4$ \\
\hline \multicolumn{9}{|l|}{ Hezel sand } \\
\hline 0 to 41 & 0.507 & 0.0282 & 0.0292 & 1.35 & 6.48 & - & - & $12.7-25.4$ \\
\hline . 41 to 400 & 0.444 & 0.0 & 0.0110 & 1.76 & 4.32 & - & - & $0.51-2.03$ \\
\hline \multicolumn{9}{|l|}{ Rupert sand } \\
\hline 0 to 400 & 0.433 & 0.0381 & - & - & 35.3 & 1.28 & 9.40 & $>25.4$ \\
\hline
\end{tabular}

\section{B.1.4. Boundary Conditions}

The upper boundary conditions for these simulations were derived from the meteorological data from the Hanford Meteorological Station (Hoitink and Burk 1994). Measured daily precipitation rates defined the water inputs; snowfall was treated as an equivalent rainfall. Wind speed, cloud cover, relative humidity, solar radiation, and maximum and minimum air temperature were used to calculate potential evaporation using the Penman Method (Doorenbos and Pruitt 1977). No attempt was made to account for the decreasing temperatures and increasing precipitation reported for progressively higher elevations on Rattlesnake Mountain (Thorp and Hinds 1977) .

At $4 \mathrm{~m}$, the lower boundary of the model domain was well below the deepest plant roots (which, for these simulations, were the shrub roots at $2 \mathrm{~m}$ ). The large depth between the deepest roots and the lower boundary allowed for the assumption that the lower boundary was subject only to the drainage process. Therefore, the lower boundary condition was specified with a unit gradient condition (i.e., free drainage). 


\section{B.1.5. Plant Information}

Plant information consisted of the method to partition potential evapotranspiration, active season, bare fraction, root length density, maximum root depth during the year, and the effectiveness of plant water withdrawal as a function of soil water suction. The pertinent plant data for the eight combinations of three vegetation and five soil types were not available. Instead, literature parameters or reasonable estimates of parameters for each plant were chosen and used for all five soils. Plant responses are subject to yearly precipitation and temperature variations, fire, diseases, nutrient cycling, grazing, and land use changes. These variations were not addressed in the simulations. Rather, the plant parameters were held constant for each simulation year.

Two methods were used to partition potential evapotranspiration into potential evaporation and potential transpiration. For cheatgrass, the method used was the cheatgrass model in UNSAT-H. For bunchgrass and shrubs, the leaf area method was used. Figure B.10 shows the leaf area variation throughout the year. The maximum value of 0.4 was taken from Link et al. (1990a), who reported leaf area for four years in a sagebrush-bunchgrass community growing on a silt loam soil on the Arid Lands Ecology Reserve. For this report, the assumption was made that leaf area would remain the same if the community were $100 \%$ of either sagebrush or bunchgrass. Figure B.10 shows the starting and ending dates of the leaf area function were chosen to coincide with the active season of the plants (as described below).

The active season of the plants determined when to calculate transpiration and when roots started or stopped growing. The active season was specified with starting and ending days of the year. Cheatgrass was started on day 32 and ended on day 166 . Actual dates depend on the weather and soil. For the starting date, Link et al. (1990b) reported the first leaves fully open by day 55 at the Grass Site (wind-blown sand mantled over sand). In a normal year on the Arid Lands Ecology Reserve, many plant species generally become active around March 1 (Rickard and Vaughan 1988). The ending (senescence) date of day 166 was chosen to match that of bunchgrass. In support of that date, Link et al. (1990b) reported a date of day 150 for cheatgrass at the Grass Site in 1986 and 1987.

For bunchgrass, the start and end days were 60 and 166, respectively. These days were estimated from Figure 6.6 of Rickard and Vaughan (1988) for a normal precipitation year for bunchgrass growing on silt loam on the Arid Lands Ecology Reserve. For shrubs, the days were 0 and 366. Although they allow for a longer growing season than the dates reported by Rickard and Vaughan (1988), these starting and ending days do not result in extra transpiration because of the limits imposed by the leaf area index (see Figure B.10).

The bare fraction of soil is used to scale the potential transpiration based on the amount of soil surface covered by the vegetation. If the bare fraction were zero, the cover percentage would be $100 \%$ and there would be no reduction in potential transpiration. For cheatgrass and bunchgrass, the bare fraction was set at 0.5 , meaning that the vegetation covered $50 \%$ of the ground surface so that potential transpiration was appropriately reduced by $50 \%$. For lack of data, the value of 0.5 was assumed. For the shrubs, the bare fraction was set at 0.8 , meaning that the shrubs covered $20 \%$ of the ground surface. Any reduction to potential transpiration caused by a less than $100 \%$ cover is added to potential evaporation. After all the manipulations, the sum of potential evaporation and potential transpiration must equal potential evapotranspiration.

Root length density data were obtained from Mayer et al. (1981). Figures B.11 to B.13 show the data and fitted functions. The maximum annual rooting depth is highly variable from plant to plant, soil to soil, and year to year. For this report, three depths were used: $0.6 \mathrm{~m}$ for cheatgrass, 


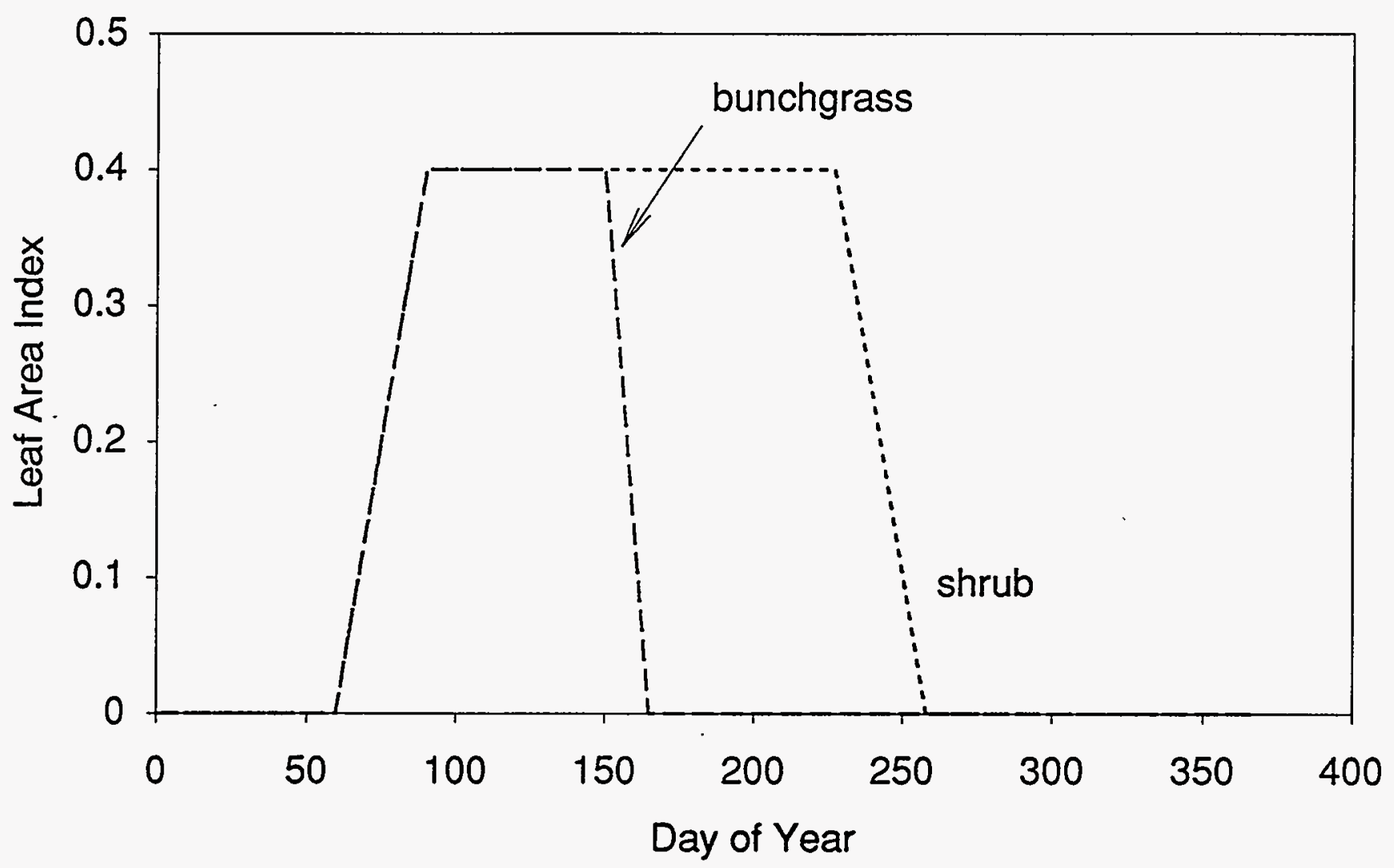

Figure B.10. Leaf Area Function for Bunchgrass and Shrub

B. 15 


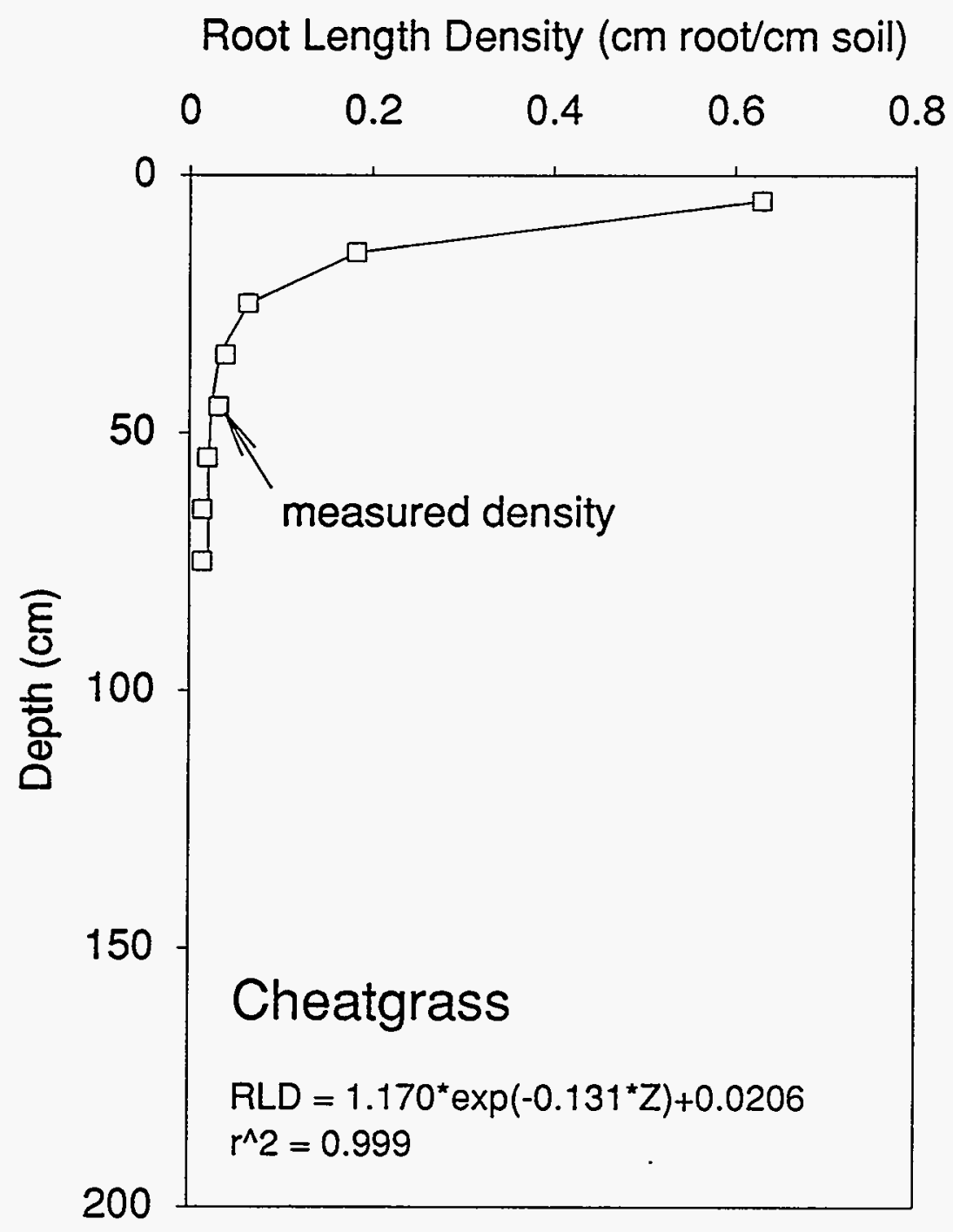

Figure B.11. Root Length Density Function for Cheatgrass 


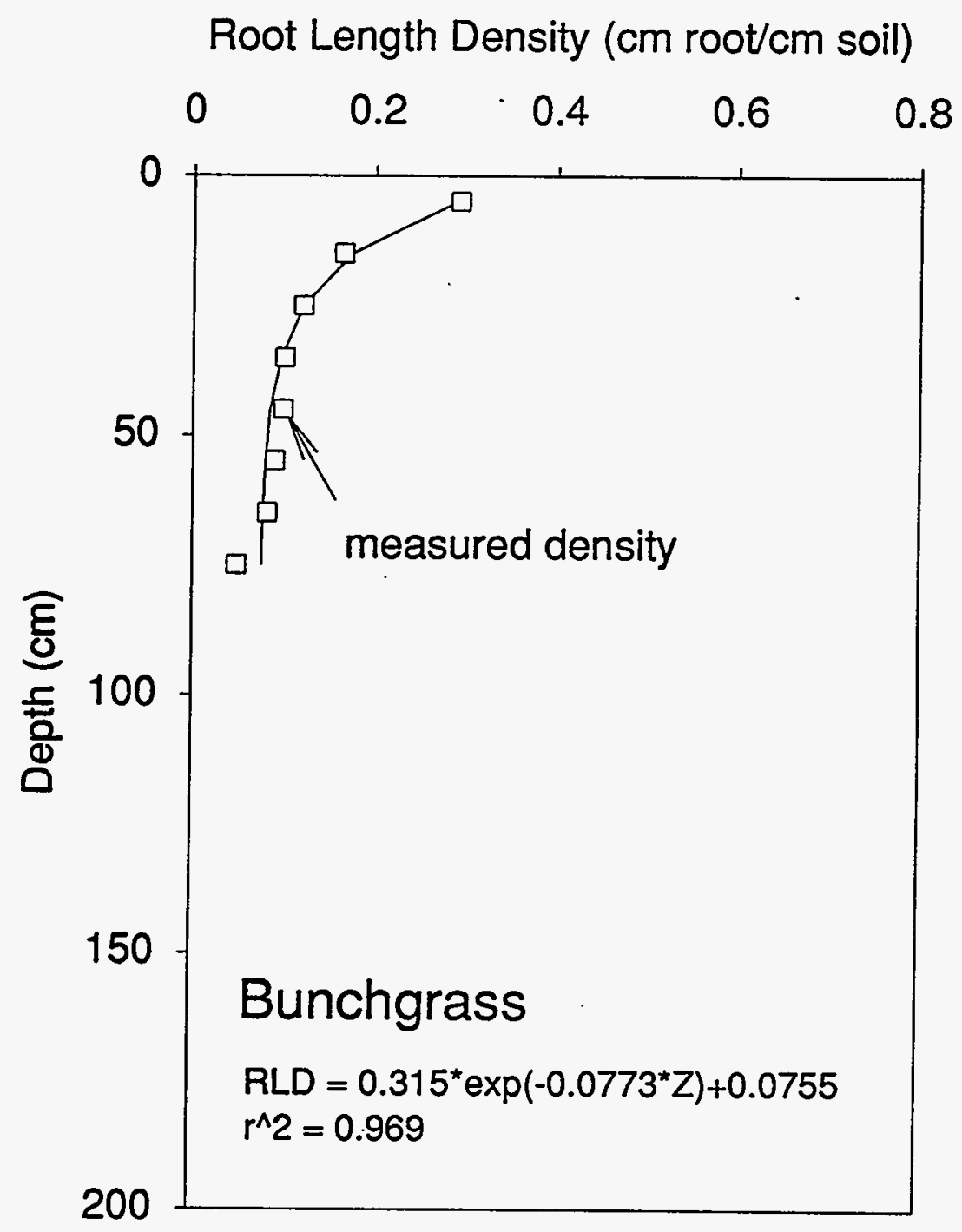

Figure B.12. Root Length Density Function for Bunchgrass 
Root Length Density (cm root/cm soil)

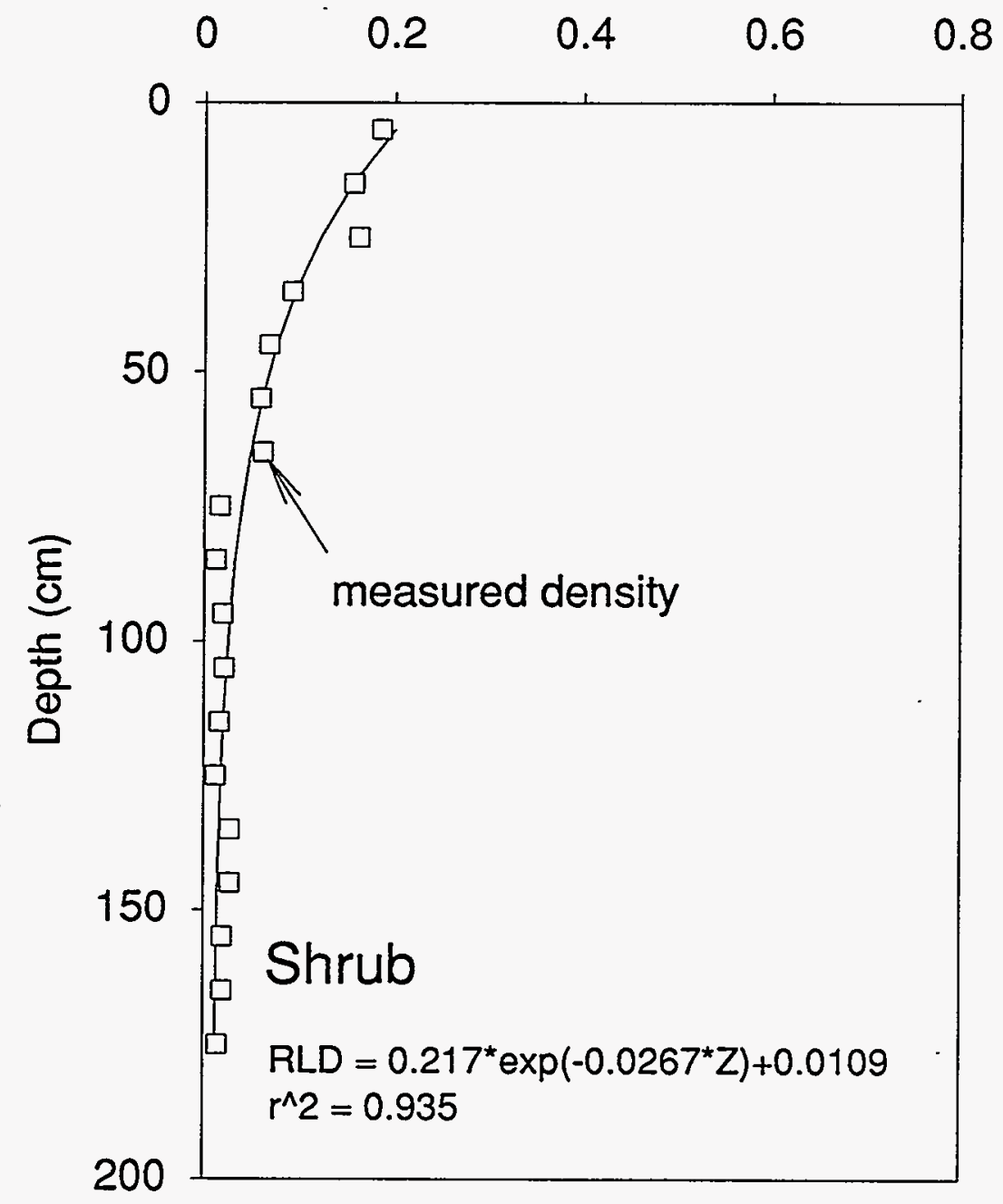

Figure B.13. Root Length Density Function for Shrub 
$1.0 \mathrm{~m}$ for bunchgrass, and $2.0 \mathrm{~m}$ for shrub. Seasonally, cheatgrass roots were allowed to grow at the rate of $1 \mathrm{~cm} / \mathrm{d}$ for their entire growing season. The roots of bunchgrass and shrubs were considered to be at their maximum depth throughout the growing season.

Figure B.14 shows how plant water uptake varied with soil water suction for the three plant types. The only values in Figure B.14 with some support are the wilting points (i.e., the highest suction at which plant water withdrawal becomes zero). For these simulations, the wilting points of cheatgrass, bunchgrass, and sagebrush were specified as 2.0,4.0, and 7.0 $\mathrm{MPa}$, respectively. Cline et al. (1977) showed that cheatgrass and bunchgrass could both remove water at suctions up to and above 1.5 MPa. Sagebrush was reported to operate in soils with suctions as high as $7.0 \mathrm{MPa}$ (Fernandez and Caldwell 1975; Branson et al. 1976).

\section{B.2 Results}

Figures B.15 to B.19 show the variations in estimated annual recharge rates for the 12 soil and vegetation combinations identified earlier. Tables B.2 to B.6 summarize the average rates as well as the minimum and maximum values during the averaging periods. The results, organized by soil type, are discussed below.

\section{B.2.1 Warden Silt Loam}

Figure B.15 shows that estimated recharge rates did not vary too much throughout the simulation period. Three time periods appear to have higher rates: the late 1950s, the mid-1970s and the mid-1980s. Table B.2 shows that the difference between the minimum and maximum rates was small; the silt loam tends to damp the occasional recharge pulses, resulting in a more uniform recharge rate.

\section{B.2.2 Ephrata Sandy Loam}

Figure B.16 shows that the estimated recharge rates varied considerably. As the vegetation type changed from no plants to cheatgrass and then to bunchgrass, the average rate decreased, showing the effect of both the presence of vegetation and the type of vegetation (shallow-rooted annual versus deep-rooted perennial). This result implies that this soil type is sensitive to disturbance; vegetation alteration or removal can lead to a significant increase in recharge. This result has implications for the Hanford Site because large areas of the 200 Areas plateau are covered by Ephrata sandy loam.

Table B.3 shows that the ratio of the maximum rate to the minimum rate for the period from 1958 to 1992 increased substantially as the vegetation type changed from no plants to bunchgrass. This result can be seen in Figure B.16, in which rates for bunchgrass are generally low, except for two or three times when rates are high in response to unusually wet weather. Such a result implies that long-term rates are determined by extreme weather events. The implication for monitoring schemes is that natural systems may not see such events for 10, 20, or even 30 years. Furthermore, if longterm rates are indeed determined by these infrequent events, the impact on tracer movement through the profile needs to be examined. These infrequent events tend to result in large fluxes during short periods, situations which are conducive to preferential flow. This type of flow invalidates one of the . basic assumptions of the tracer method, that water moves as piston flow. 


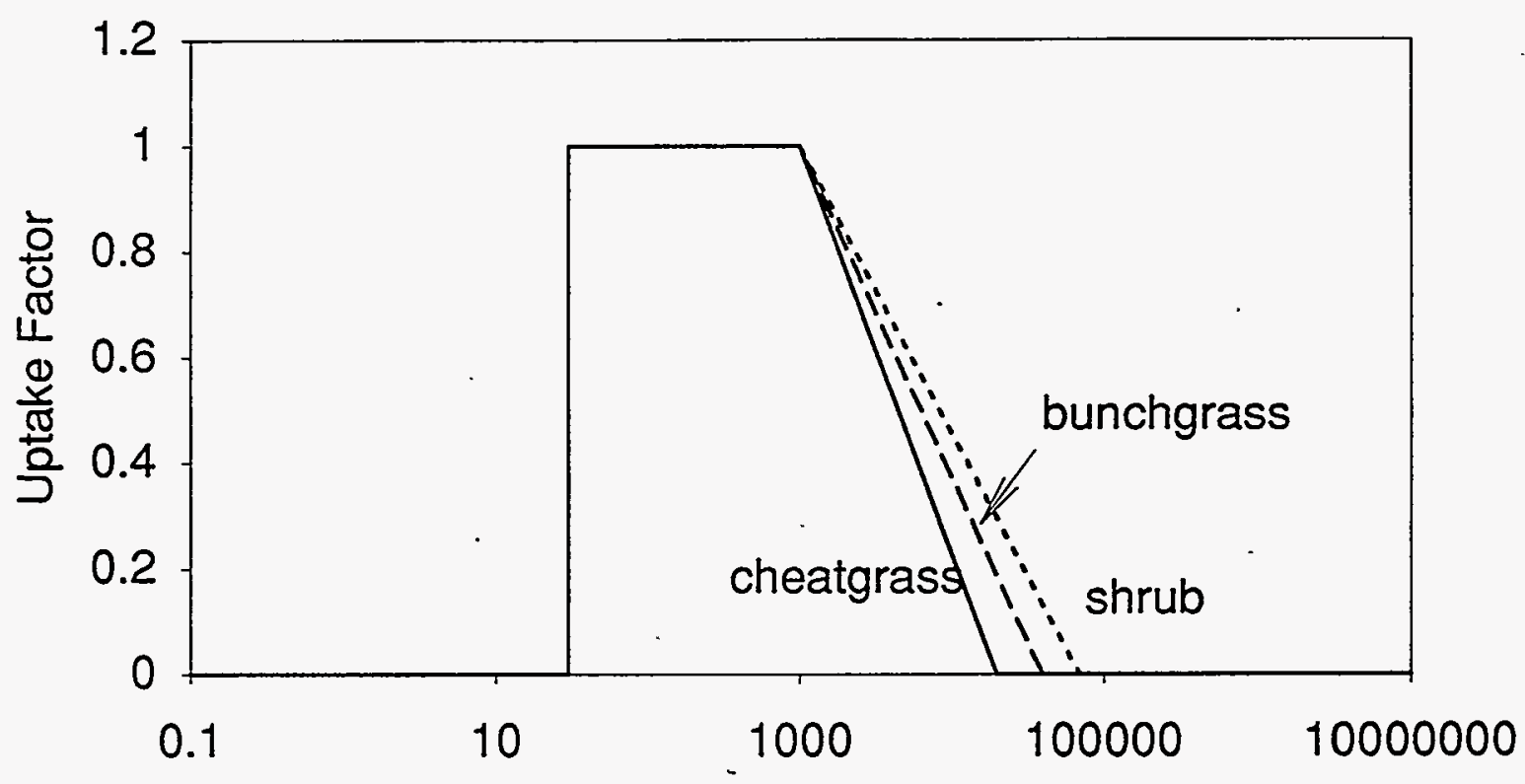

Suction Head (cm)

Figure B.14. Plant Water Uptake Function for Cheatgrass, Bunchgrass, and Shrub

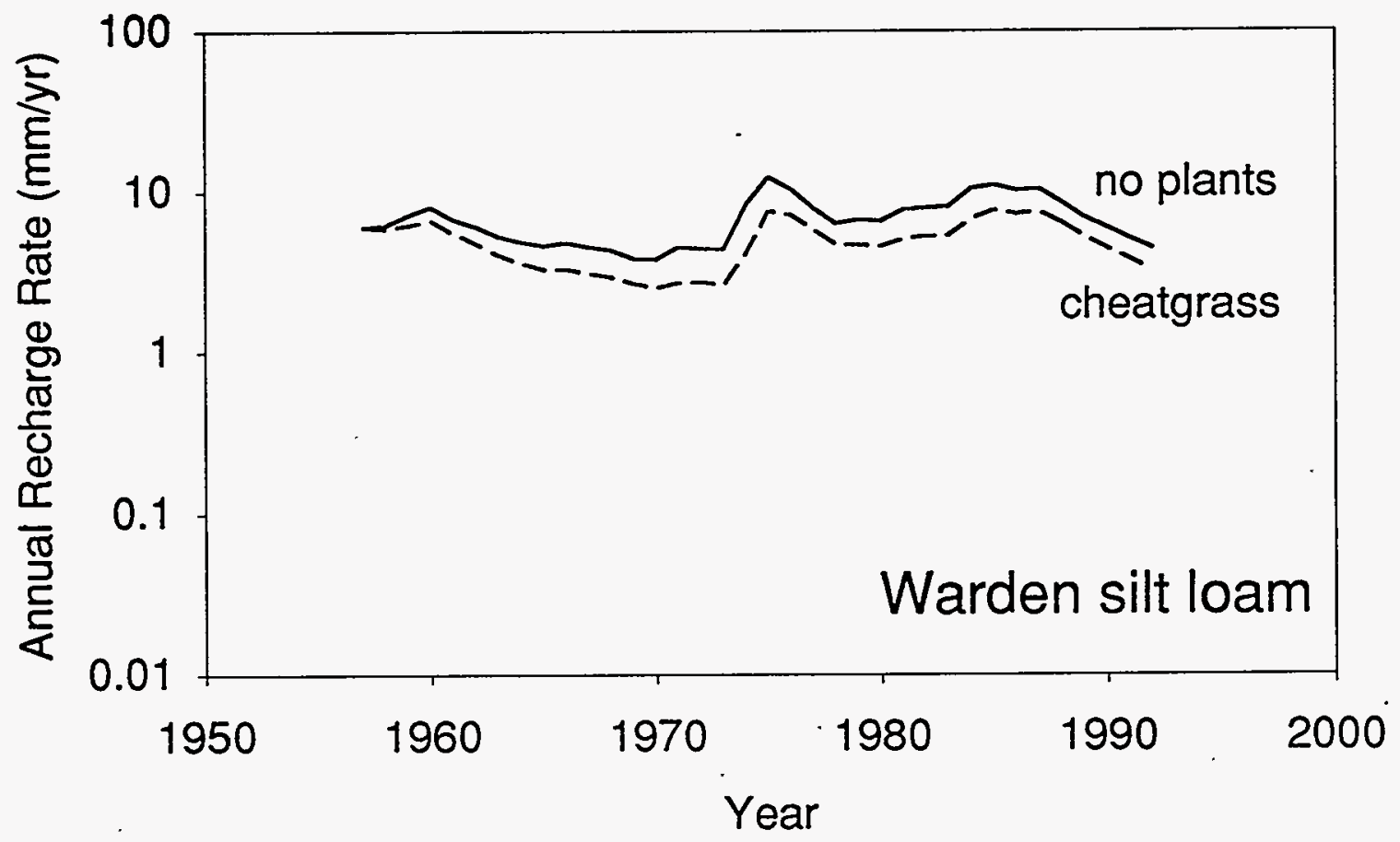

Figure B.15. Simulated Recharge Rates for Warden Silt Loam 


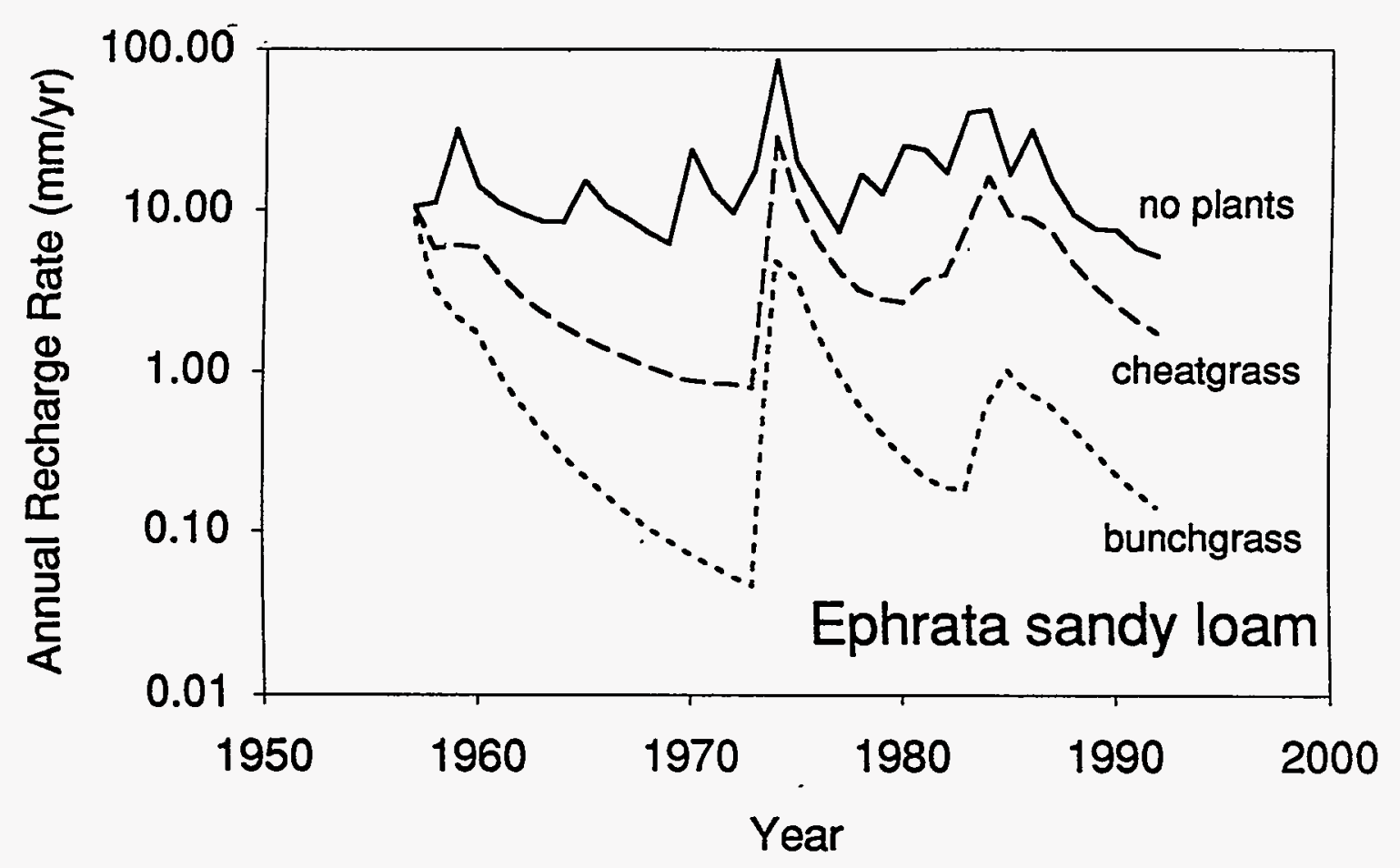

Figure B.16. Simulated Recharge Rates for Ephrata Sandy Loam

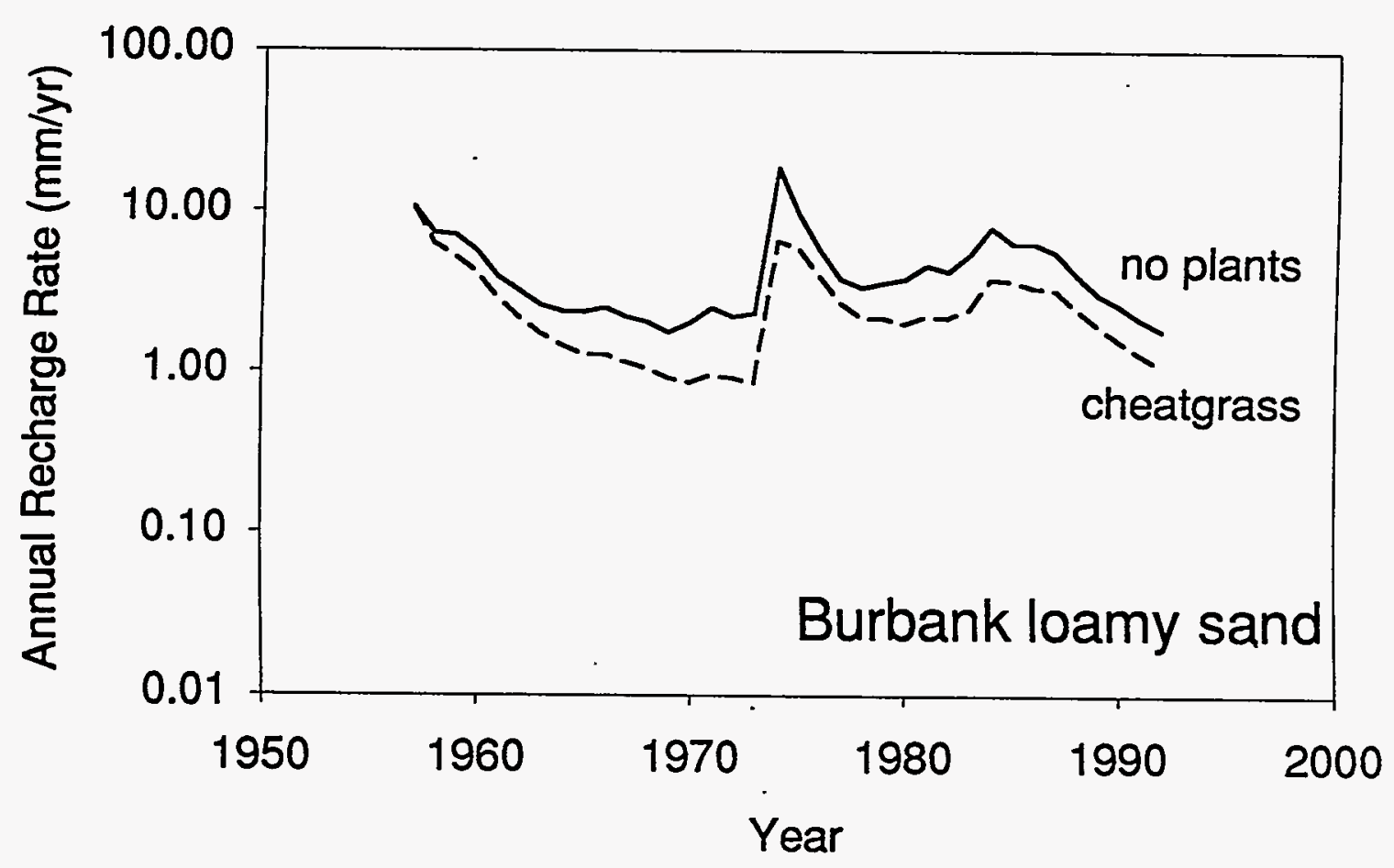

Figure B.17. Simulated Recharge Rates for Burbank Loamy Sand 


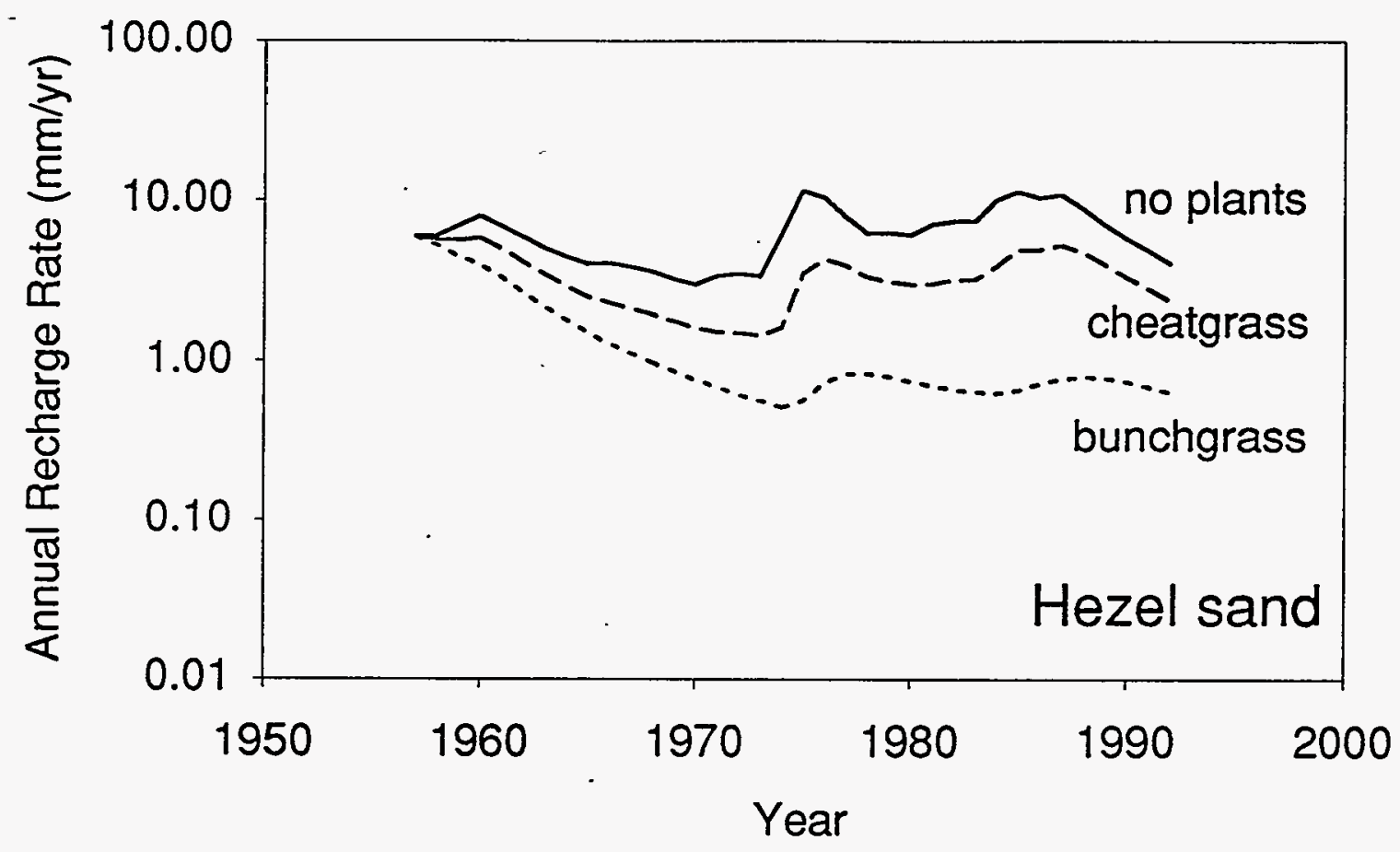

Figure B.18. Simulated Recharge Rates for Hezel Sand

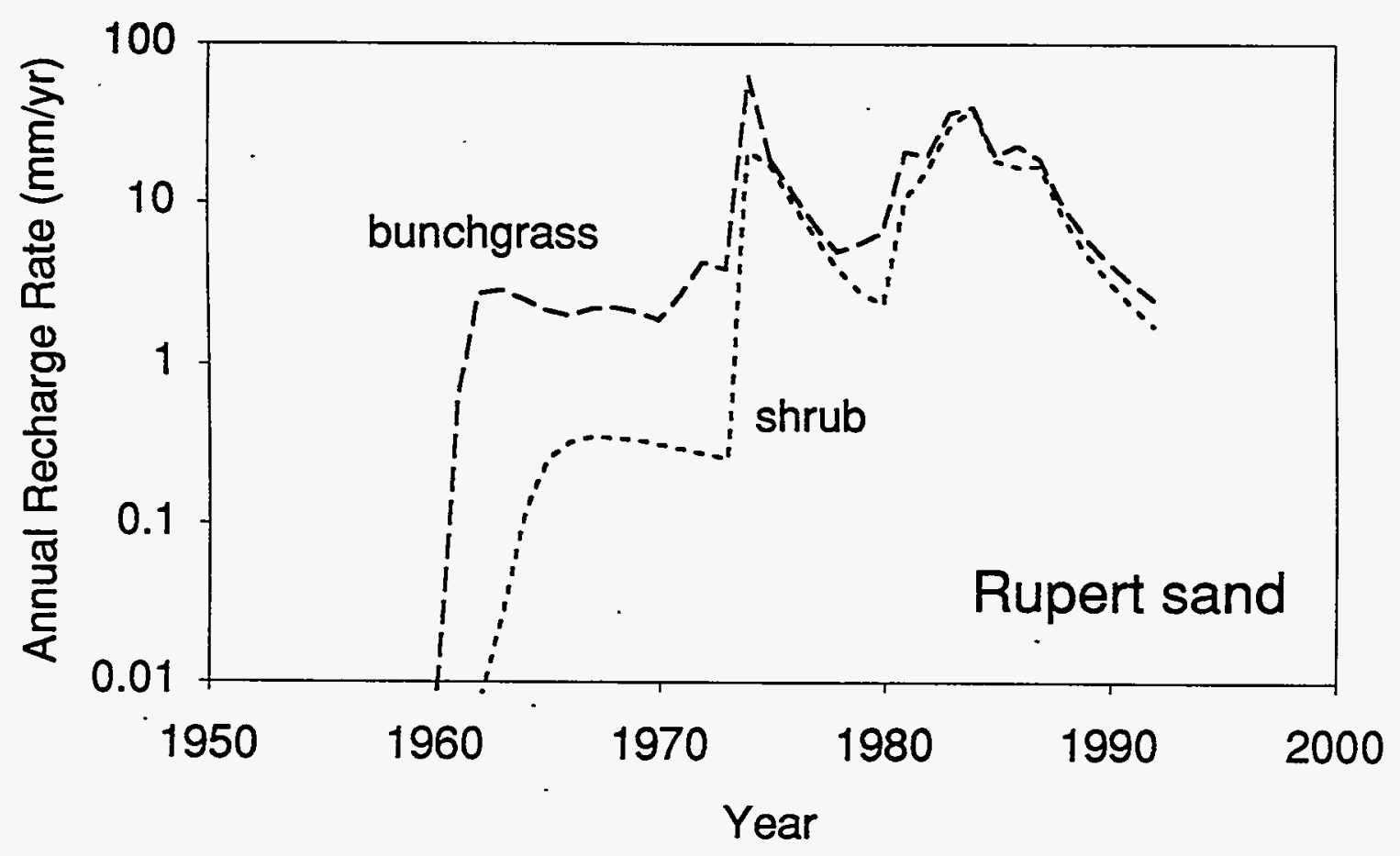

Figure B.19. Simulated Recharge Rates for Rupert Sand 
Table B.2. Simulation Summary for Warden Silt Loam, 1958-1992

\begin{tabular}{||c|c|c|c||}
\hline \multirow{2}{*}{ Vegetation Type } & \multicolumn{3}{|c|}{ Simulated Recharge Rates (mm/yr) } \\
\cline { 2 - 4 } & Average & Minimum & Maximum \\
\hline Cheatgrass & 4.8 & 2.5 & 7.6 \\
\hline No plants & 6.8 & 3.8 & 12.3 \\
\hline
\end{tabular}

Table B.3. Simulation Summary for Ephrata.Sandy Loam, 1958-1992

\begin{tabular}{||c|c|c|c||}
\hline \multirow{2}{*}{ Vegetation Type } & \multicolumn{3}{|c||}{ Simulated Recharge Rates (mm/yr) } \\
\cline { 2 - 4 } & Average & Minimum & Maximum \\
\hline Bunchgrass & 1.0 & 0.05 & 8.9 \\
\hline Cheatgrass & 4.9 & 0.79 & 28.5 \\
\hline No plants & 17.3 & 5.2 & 85.2 \\
\hline
\end{tabular}

Table B.5. Simulation Summary for Hezel Sand, 1970-1992 for Bunchgrass and 1958-1992 for Cheatgrass and no Plants

\begin{tabular}{||c|c|c|c||}
\hline \multirow{2}{*}{ Vegetation Type } & \multicolumn{3}{|c|}{ Simulated Recharge Rates (mm/yr) } \\
\cline { 2 - 4 } & Average & Minimum & Maximum \\
\hline Bunchgrass & 0.70 & 0.52 & 0.84 \\
\hline Cheatgrass & 3.4 & 1.4 & 5.8 \\
\hline No plants & 6.4 & 3.0 & 11.5 \\
\hline
\end{tabular}

Table B.6. Simulation Summary for Rupert Sand, 1962-1992 for Bunchgrass, 1966-1992 for Shrub

\begin{tabular}{|c|c|c|c||}
\hline \multirow{2}{*}{ Vegetation Type } & \multicolumn{3}{|c|}{ Simulated Recharge Rates (mm/yr) } \\
\cline { 2 - 4 } & Average & Minimum & Maximum \\
\hline Shrub & 8.6 & 0.25 & 38.8 \\
\hline Bunchgrass & 11.3 & 1.9 & 61.9 \\
\hline
\end{tabular}




\section{B.2.3 Burbank Loamy Sand}

Figure B.17 and Table B.4 show that the estimated annual recharge rates for this soil type were lower than the rates for the Ephrata sandy loam. In particular, the rate under no plants shows this soil to be less sensitive to disturbance than the Ephrata sandy loam. This result is understandable when viewed in the context of the hydraulic properties. Water retention in the Ephrata sandy loam is much less than in the Burbank loamy sand despite texture differences that would indicate otherwise. This result highlights the sensitivity of recharge to hydraulic properties and indicates that general soil parameters, such as used to represent the Ephrata and Burbank soils, can only give estimates of recharge that are qualitative at best.

The response of annual recharge rates was similar to the response in other soils in that the highest rates occurred at the three times previously discussed. Again, the similarity of the response shows that infrequent weather conditions can have an impact both across all soil types and for many years afterwards.

\section{B.2.4 Hezel Sand}

Figure B.18 shows that the estimated annual recharge rates for this soil type with bunchgrass were affected by the initial conditions. Because of this, the average rate was determined for a subset of the simulation years (i.e., 1970-1992). Table B.5 shows that the average rates were lower than the Ephrata sandy loam, and the range was much smaller. The subsurface silt layer seems to dampen the recharge pulses, resulting in less year-to-year variation. This effect was also observed in the Warden silt loam.

\section{B.2.5 Rupert Sand}

Figure B.19 shows that the initial conditions affected the simulations. Therefore, the averaging period for the bunchgrass simulation was reduced to 1962-1992, and the period for the shrub simulation was reduced to 1966-1992. The rates show two marked peaks, one in the mid-1970s and the other in the mid-1980s. Once again, the results show that large recharge pulses occur infrequently. In contrast to the Ephrata sandy loam and Hezel sand, the estimated annual rates for the Rupert sand with bunchgrass were high. Even under the shrub cover, the recharge rate for Rupert sand was higher than the no plant rates for.the Warden silt loam, Burbank loamy sand, and Hezel sand. After 1975, the two simulations predicted similar rates whereas the expectation was that the shrub cover would have significantly lower rates. That the simulation results were similar mostly reflects the difference in cover percentage (i.e., $50 \%$ for bunchgrass and $20 \%$ for shrub).

\section{References}

Branson, F. A., R. F. Miller, and I. S. McQueen. 1976. "Moisture Relationships in Twelve Northern Desert Shrub Communities near Grand Junction, Colorado." Ecology 57:1104-1124.

Cline, J. F., D. W. Uresk, and W. H. Rickard. 1977. "Comparison of Soil Water Used by a Sagebrush-Bunchgrass and a Cheatgrass Community." J. Range Mgmt. 30:199-201.

Connelly, M. P., J. V. Borghese, C. D. Delaney, B. H. Ford, J. W. Lindberg, and S. J. Trent. Hydrogeologic Model for the 200 East Groundwater Aggregate Area. WHC-SD-EN-TI-019, Rev. 0., Westinghouse Hanford Company, Richland, Washington. 
Doorenbos, J., and W. O. Pruitt. 1977. Guidelines for Predicting Crop Water Requirements. FAO Irrigation Paper No. 24, Food and Agriculture Organization of the United Nations, Rome, Italy, pp. 1-107.

Fayer, M. J., and T. L. Jones. 1990. UNSAT-H Version 2.0: Unsaturated Soil Water and Heat Flow Model. PNL-6779, Pacific Northwest Laboratory, Richland, Washington.

Fayer, M. J., and G. W. Gee. 1992. "Predicted Drainage at a Semiarid Site: Sensitivity to Hydraulic Property Description and Vapor Flow." In Proceedings of the International Workshop on Indirect Methods for Estimating the Hydraulic Properties of Unsaturated Soils, M. Th. van Genuchten, F .J. Leij, and L.J. Lund, eds., Riverside, California, October 11-13, 1989, University of California, Riverside.

Fernandez, O. A., and M. M. Caldwell. 1975. "Phenology and Dynamics of Root Growth of Three Cool Semi-Desert Shrubs Under Field Conditions." J. Ecol. 63:703-714.

Hajek, B. F. 1966. Soil Survey, Hanford Project in Benton County Washington. BNWL-243, Pacific Northwest Laboratory, Richland, Washington.

Hoitink, D. J., and K. W. Burk. 1994. Climatological Data Summary 1993 with Historical Data. PNL-9809, Pacific Northwest Laboratory, Richland, Washington.

Kocher, A. E., and A. T. Strahorn. 1919. Soil Survey of Benton County, Washington. U.S. Government Printing Office, Issued 1919.

Link, S. O., G. W. Gee, M. E.Thiede, and P. A. Beedlow. 1990a. "Response of a Shrub-Steppe Ecosystem to Fire: Soil Water and Vegetational Change." Arid Soil Research and Rehabilitation, 4:163-172.

Link, S. O., G. W. Gee, and J. L. Downs. 1990b. "The Effect of Water Stress on Phenological and Ecophysiological Characteristics of Cheatgrass and Sandberg's Bluegrass." J. Range Mgmt. 43:506-513.

Mayer, D. W., P. A. Beedlow, and L. L. Cadwell. 1981. Moisture Content Analysis of Covered Uranium MIll Tailings. PNL-4132, Pacific Northwest Laboratory, Richland, Washington.

Rickard, W. H., and B. E. Vaughan. 1988. "Plant Community Characteristics and Responses." In Shrub-Steppe Balance and Change in a Semi-Arid Terrestrial Ecosystem. W. H. Rickard et al., ed., Developments in Agricultural and Managed-Forest Ecology 20, Elesevier Science Publishers, New York

Rockhold, M. L., M. J. Fayer, and G. W. Gee. 1988. Characterization of Unsaturated Hydraulic Conductivity at the Hanford Site. PNL-6488, Pacific Northwest Laboratory, Richland, Washington.

Rockhold, M. L., M. J. Fayer, and P. R. Heller, 1993. Physical and Hydraulic Properties of Sediments and Engineered Materials Associated with Grouted Double-Shell Tank Waste Disposal at Hanford. PNL-8813, Pacific Northwest Laboratory, Richland, Washington.

Ross, B. 1990. "A Conceptual Model of Deep Unsaturated Zones with Negligible Recharge." Water Resour. Res. 20:1627-1629. 
Thorp, J. M., and W. T. Hinds. 1977. Microclimates of the Arid Lands Ecology Reserve. BNWL-SA-6231, Pacific Northwest Laboratory, Richland, Washington.

USDA. 1971. Soil Survey, Benton County Area, Washington. U.S. Department of Agriculture, Washington, D.C. Issued July 1971. 


\section{Distribution}

No. of

Copies

\section{OFFSITE}

12 DOE/Office of Scientific and Technical Information

B. J. Andraski

U.S. Geological Survey

$333 \mathrm{~W}$. Nye Lane

Carson City, NV 89706

3 D. Lundstrom

Washington State Department of Ecology

P.O. Box 1386

Richland, WA 99352

B. Blake

133 1st Avenue North

Minneapolis, MN 55401

R. Buck, Jr.

Wanapum Indian Band

P.O. Box 878

Ephrata, WA

R. A. Danielson

Washington State Department of Health

2 South 45th Ave.

Yakima, WA 98908

B. Drost

U.S. Geological Survey

1201 Pacific Avenue, Suite 600

Tacoma, WA 98402

J. Erickson

Washington State Department of Health

Division of Radiation Protection

Airdustrial Center

Building 5, M.S. L-13

Olympia, WA 98503

J. Hendrickx

Department of Geosciences

New Mexico Institute of Mining and Technology

Socorro, NM. 87801
No. of

Copies

S. Harris

Environmental Restoration/

Waste Management

Nez Perce Tribe

P.O. Box 365

Lapwai, ID 83540-0365

R. Jim

Yakama Indian Nation

Environmental Restoration/Waste Management

P.O. Box 151

Toppenish, WA 98948

R. J. Luxmoore

Oak Ridge National Laboratory

P.O. Box 2008

Oak Ridge, TN 37831

R. Patt

Oregon State Department of Water Resources

3850 Portland Road

Salem, OR 97310

Dr. B. Scanlon

Bureau of Economic Geology

University of Texas

University Station Box X

Austin, TX 78713-7508

E. Springer

Los Alamos National Laboratory

P.O. Box 1663

Los Alamos, NM 87545

J. R. Wilkerson

Environmental Planning/

Rights Protection

Confederated Tribes of the Umatilla Indian Reservation

P.O. Box 638

Pendleton, OR 97801 
No. of

Copies

$5 \quad$ U.S. Geological Survey

1201 Pacific Ave., Suite 600

Tacoma, WA 98402

Attn: H. H. Bauer

W. R. Bidlake

E. A. Prych

W. Staubitz

J. J. Vaccaro

\section{ONSITE}

13 DOE Richland Operations Office
G. M. Bell
R. F. Brich
M. J. Furman
J. D. Goodenough
J. B. Hall
R. D. Hildebrand
R. G. Holt
R. G. McLeod
D. Olson
P. M. Pak
R. K. Stewart
K. M. Thompson
D. Wanek

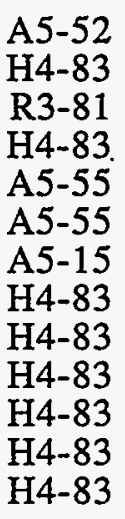

12 Bechtel Hanford, Inc.

M. P. Connelly

K. R. Fecht

B. H. Ford

G. L. Kasza

A. J. Knepp

M. J. Lauterbach

W. J. McMahon

K. R. Simpson

L. C. Swanson

S. J. Trent

D. C. Weekes

S. R. Weil

H6-04

H4-80

H4-80

H6-04

H4-80

H6-01

H6-04

H6-07

H6-03

$\mathrm{H} 4-80$

H4-82

H4-80

2 CH2M-Hill

R. L. Jackson

H6-04

R. E. Peterson

H6-05

2 U.S. Army Corps of Engineers

W. L. Greenwald

M. P. Johansen

A5-20

A5-19
No. of

Copies

3 U.S. Environmental Protection Agency

P. R. Beaver

B5-01

L. E. Gadbois

B5-01

D. R. Sherwood

B5-01

12 Westinghouse Hanford Company

D. B. Barnett

J. W. Cammann

H6-06

L. B. Collard

M. J. Hartman

H6-06

V. G. Johnson

H6-30

H6-06

H6-06

R. Khaleel

A. G. Law

$\mathrm{H} 0-36$

F. M. Mann

H6-06

J. A. Rawlins

$\mathrm{H} 0-36$

H0-36

S. P. Reidel

J. S. Schmid

Public Reading Room

H6-06

H6-06

$\mathrm{H} 2-53$

46 Pacific Northwest Laboratory

M. P. Bergeron

K9-33

B. N. Bjornstad

R. W. Bryce

$\mathrm{K} 9-48$

K6-96

M. A. Chamness K9-48

C. R. Cole

K9-36

J. L. Devary

J. L. Downs

P. E. Dresel

G. W. Gee

M. J. Fayer (10)

M. D. Freshley

K. A. Hoover

R. E. Jaquish

C. T. Kincaid

$\mathrm{K} 9-36$

K6-63

K6-96

K9-33

K9-33

K9-36

K9-33

$\mathrm{K} 9-25$

K9-33

R. R. Kirkham

G. V. Last

T. L. Liikala

S. P. Luttrell

P. D. Meyer

E. M. Murphy

M. L. Rockhold

R. Schalla

J. E. Szecsocdy

F. A. Spane, Jr.

P. D. Thorne

V. R. Vermeul
K9-33

K9-48

K9-48

K6-96

K9-36

K3-61

K9-33

K6-96

K9-36

K6-96

K6-96

K6-96 
No. of

Copies

T. B. Walters

K6-96

W. D. Webber

M. S. Witkowski

K6-96

S. K. Wurstner

K6-96

Publishing Coordination

K9-36

Technical Report Files (5)

K1-06

\section{Routing}

R. W. Bryce

K9-34

R. M. Ecker

SE-UI

M. J. Graham

K9-38

S. A. Rawson

R. L. Skaggs

K9-34

P. C. Hays (last)

K9-34

K9-41

Distr.3 